\title{
Natural Compounds as Target Biomolecules in Cellular Adhesion and Migration: From Biomolecular Stimulation to Label-Free Discovery and Bioactivity-Based Isolation
}

\author{
Beatrix Péter 1,*D , Imre Boldizsár ${ }^{2,3}{ }^{\mathbb{D}}$, Gábor M. Kovács ${ }^{2,4}$, Anna Erdei ${ }^{5,6}$, Zsuzsa Bajtay ${ }^{5,6}$, Alexandra Vörös ${ }^{1}$, \\ Jeremy J. Ramsden ${ }^{7}$, Ildikó Szabó ${ }^{8,9}$, Szilvia Bósze ${ }^{8,9}{ }^{\mathbb{D}}$ and Robert Horvath ${ }^{1}$ (D)
}

1 Nanobiosensorics Group, Research Centre for Energy Research, Institute for Technical Physics and Materials Science, Konkoly-Thege u 29-33, 1120 Budapest, Hungary; aavoros@gmail.com (A.V.); r74horvath@gmail.com (R.H.)

2 Department of Plant Anatomy, Institute of Biology, Eötvös Loránd University, 1117 Budapest, Hungary; boldizsarimi@gmail.com (I.B.); gaborm.kovacs@ttk.elte.hu (G.M.K.)

3 Department of Pharmacognosy, Semmelweis University, Üllői út 26, 1085 Budapest, Hungary

4 Plant Protection Institute, Centre for Agricultural Research, Hungarian Academy of Sciences, 1022 Budapest, Hungary

5 Department of Immunology, Eötvös Loránd University, 1117 Budapest, Hungary; anna8erdei@gmail.com (A.E.); bajtay.zsuzsanna@ttk.elte.hu (Z.B.)

6 MTA-ELTE Immunology Research Group, Eötvös Loránd Research Network (ELKH), Eötvös Loránd University, 1117 Budapest, Hungary

Citation: Péter, B.; Boldizsár, I.; Kovács, G.M.; Erdei, A.; Bajtay, Z.; Vörös, A.; Ramsden, J.J.; Szabó, I.; Bősze, S.; Horvath, R. Natural Compounds as Target Biomolecules in Cellular Adhesion and Migration: From Biomolecular Stimulation to Label-Free Discovery and Bioactivity-Based Isolation. Biomedicines 2021, 9, 1781. https:// doi.org/10.3390/biomedicines9121781

Academic Editor: Sharon Marx

Received: 25 October 2021

Accepted: 22 November 2021

Published: 26 November 2021

Publisher's Note: MDPI stays neutral with regard to jurisdictional claims in published maps and institutional affiliations.

Copyright: (c) 2021 by the authors. Licensee MDPI, Basel, Switzerland. This article is an open access article distributed under the terms and conditions of the Creative Commons Attribution (CC BY) license (https:// creativecommons.org/licenses/by/ $4.0 /)$.
7 Clore Laboratory, University of Buckingham, Buckingham MK18 1EG, UK; jeremy.ramsden@buckingham.ac.uk

8 MTA-ELTE Research Group of Peptide Chemistry, Eötvös Loránd Research Network (ELKH), Institute of Chemistry, Eötvös Loránd University, 1117 Budapest, Hungary; szaboi8@gmail.com (I.S.); szilvia.bosze@gmail.com (S.B.)

9 National Public Health Center, Albert Flórián út 2-6, 1097 Budapest, Hungary

* Correspondence: peter.beatrix@energia.mta.hu

\begin{abstract}
Plants and fungi can be used for medical applications because of their accumulation of special bioactive metabolites. These substances might be beneficial to human health, exerting also anti-inflammatory and anticancer (antiproliferative) effects. We propose that they are mediated by influencing cellular adhesion and migration via various signaling pathways and by directly inactivating key cell adhesion surface receptor sites. The evidence for this proposition is reviewed (by summarizing the natural metabolites and their effects influencing cellular adhesion and migration), along with the classical measuring techniques used to gain such evidence. We systematize existing knowledge concerning the mechanisms of how natural metabolites affect adhesion and movement, and their role in gene expression as well. We conclude by highlighting the possibilities to screen natural compounds faster and more easily by applying new label-free methods, which also enable a far greater degree of quantification than the conventional methods used hitherto. We have systematically classified recent studies regarding the effects of natural compounds on cellular adhesion and movement, characterizing the active substances according to their organismal origin (plants, animals or fungi). Finally, we also summarize the results of recent studies and experiments on SARS-CoV-2 treatments by natural extracts affecting mainly the adhesion and entry of the virus.
\end{abstract}

Keywords: natural compound; cell adhesion; movement; CAM; integrin; viability; biosensors; preparation; isolation; SARS-CoV-2

\section{Introduction}

Natural medicines, extracted from herbs and other living sources such as serpent venoms, have been used by humans since the earliest times. In contrast, the use of mineral substances as medicines was an innovation of Paracelsus introduced as recently as the 
16th century AD. Today, there is renewed interest in natural substances for curing illnesses, both directly and as inspirations for manufactured pharmaceuticals (for example, an antimalaria agent extracted from the sweet wormwood plant [1]). Many people prefer to take mixtures of herbs as alternatives to industrial medicine, which often causes deleterious side effects [2]. Plants (and fungi) synthesize a large number of specific compounds called secondary metabolites (SMs). The function of SMs in plants and fungi is not fully understood; however, many of these compounds can be used for medicinal purposes. They have special significance in cancer therapy: among compounds introduced since the 1940s, almost $50 \%$ were isolated, purified SMs or their semi-synthetic derivatives [3].

The study of the mode of action of natural substances at the cellular and molecular levels only began a few years ago with the advent of modern techniques. Compared to manufactured pharmaceuticals systematic scientific evidence for the efficacy and safety of natural substances is generally still lacking [2]. When studying SMs, the major challenge is to elucidate their effective targets, which are responsible for the medicinal effects of these natural compounds. In contrast with synthetic drugs the target is usually preselected, and the challenge is to find a molecule that binds to the target and not the others.

We suggest that these substances influence primarily at the cellular level. The general approach has been to apply labeling techniques to investigate effects on cell adhesion, migration, motility etc. in vitro [1]. We shall review new, label-free techniques for monitoring cell adhesion and spreading directly, without label-induced perturbation.

Cell adhesion is crucial for the assembly of individual cells into tissues [4]. It is responsible for the overall architecture of the tissue [4]. Monitoring cell adhesion and spreading is important because these processes maintain the multicellular tissue structure, and individual cell migration, survival, proliferation, differentiation, gene expression, cellcell communication and immunity, and cancer metastasis [1]. Thus, studying the adhesion and spreading of the treated cells by natural compounds helps to understand their effects on metabolism, development and physiology.

In this review we summarize the effects of natural compounds from plants, fungi and snake venom on cellular adhesion and movement, and the methods applied to reveal these effects. Finally, we mention some possible ways to prevent or reduce symptoms of COVID-19 by applying natural compounds according to the recent literature in this topic.

\section{Relationship between Adhesion, Movement and Inflammation}

Inflammation is typified by the accumulation of leukocytes and other mesenchymal cells in response to attractant molecules at sites of injury or infection [5-7]. Leukocytes become activated after being exposed to chemoattractants and are capable of adhering tightly to the endothelium [7]. Cytokines and endotoxins stimulate the endothelium to become more adhesive for leukocytes $[5,7,8]$. The general classes of cell adhesion molecules (CAM) are integrins, selectins, the immunoglobulin superfamily of cell adhesion molecules and cadherins [5,7,9]. Integrins and selectins on circulating leukocytes mediate their adhesion to the endothelium, whereas selectins and members of the immunoglobulin superfamily on the endothelium mediate their affinity for leukocytes [7,9]. CAMs are known to play a critical role in the recruitment of cells into various tissues and in the maintenance and regulation of the integrity of the tissues [5].

CAM expression is tightly regulated in normal tissue environment; however, inappropriate expression of CAMs disrupts normal cell-cell and cell-matrix interactions, facilitating tumour formation.

Integrins are prime regulators of communication between cells and their microenvironment. These evolutionarily old cellular adhesion receptors play an important role in physiological and pathological processes. These large molecules are responsible for the attachment of cells to the extracellular matrix (ECM) components and cell-to-cell interactions. Integrin heterodimers are composed of noncovalently bound $\alpha$ and $\beta$ subunits. 
In vertebrates the integrin family is composed of $18 \alpha$ subunits and $8 \beta$ subunits that form 24 different heterodimeric complexes [10] (Figure 1). The integrins can be grouped into subgroups based on their subunit composition and ligand-binding specificity.

A subgroup of integrins (8 out of 24) recognize proteins (such as fibronectin and vitronectin) that contain the Arg-Gly-Asp (RGD) sequence. The collagen binding integrins $\alpha 1 \beta 1, \alpha 2 \beta 1, \alpha 10 \beta 1$, and $\alpha 11 \beta 1$ are able to recognize the triple-helical GFOGER collagen sequence. The laminin receptors $\alpha 3 \beta 1, \alpha 6 \beta 1$ and $\alpha 7 \beta 1$ mediate adhesion to basement membrane laminins. Vertebrates also have leukocyte-specific integrins that mediate cellcell adhesion. The $\beta 2$ integrins are present on the cell surface in a normally inactive state, in which they do not bind ligands. An activation signal like an inflammatory stimulus results in a conformational change of the integrin, increasing its ability to bind the ligand. Activated $\beta 2$ integrins play an important role in cellular adhesion, migration and phagocytosis.

The lack of the $\beta$ subunit can block preimplantation development $(\beta 1)$ and perinatal lethality $(\beta 8)$ and is involved in various defects of leukocyte function $(\beta 2, \beta 7)$, inflammation $(\beta 6)$, hemostasis and angiogenesis ( $\beta 3)$. Integrins frequently intercommunicate; that is, they are able to activate or inhibit each other's function [10].

The CD11/CD18 $\beta 2$ integrins are specifically expressed on circulating leukocytes, and play a significant role in fast adhesion to endothelial cells $[7,9]$. The intercellular adhesion molecule-1 (ICAM-1) and vascular cellular adhesion molecule-1 (VCAM-1) are wellcharacterized endothelial cell ligands for CD11/CD18 [7,11]. The endothelial cell surface quantity of molecules like ICAM-1 is increased with the release of some proinflammatory cytokines from lymphocytes; an environment is thereby generated in which the leukocytes are more chemoreceptive to arterial walls during inflammatory processes [5]. Recruitment of arterial leukocytes is a significant step in the progression of different inflammatory diseases, such as rheumatism [12,13], liver inflammation [13,14], atherosclerosis [13,14], and inflammatory bowel disease [13]. Medical plant extracts may alter pathological mechanisms via the modulation of adhesion molecules [5]; this general observation will be analyzed and systematized below.

All morphogenetic processes are affected by cell migration, which contributes to many illnesses, including cardiovascular disease and cancer [15]. In general, cell movement begins with extension of the membrane followed by the formation of new adhesive protrusions at the front, which link the actin cytoskeleton to the substratum, generating traction forces that move the cell forwards; adhesive protrusions at the rear are simultaneously dismantled [15]. The cycle of forming and dismantling of adhesive structures drives migration [15]. Rho GTPases have an important role in this process; they regulate actin polymerization and myosin II activity and, therefore, adhesion dynamics [15].

The adhesion molecules driving migration are the same as those involved in the inflammatory response, but their expression and ligand-binding capacity depend on the stimuli. 


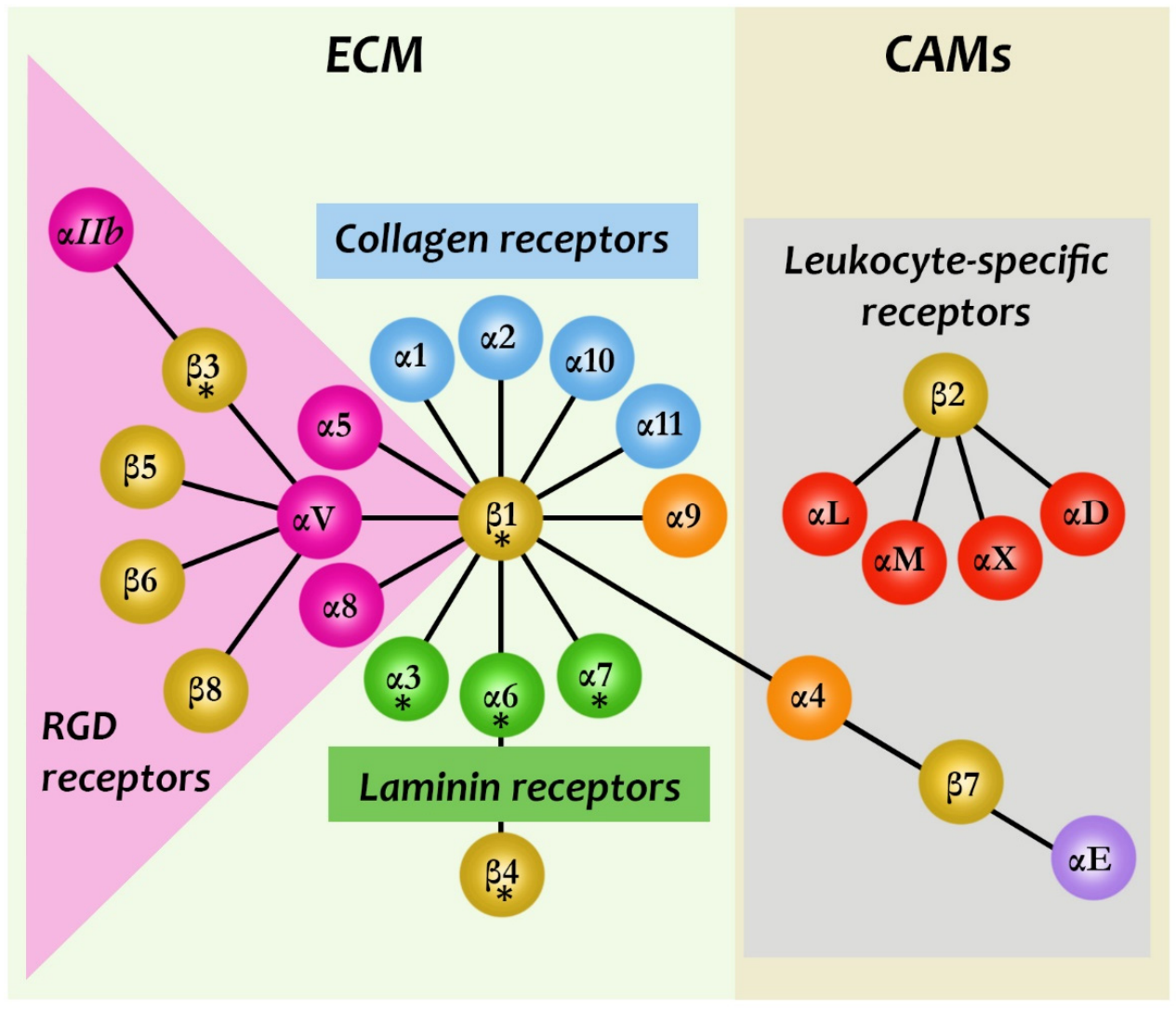

Figure 1. Integrin family members and their ligands. Integrins are transmembrane heterodimer molecules containing $\alpha$ and $\beta$ subunits. The figure illustrates the association of these subunits occurring in mammalian cells. As shown, $18 \alpha$ and $8 \beta$ subunits form 24 different, distinct integrins. These can be grouped in subfamilies based on evolutionary relationships (different colors of $\alpha$ subunits), ligand specificity and, in the case of $\beta 2$ and $\beta 7$ integrins, restricted expression on white blood cells. Integrins can be grouped into two larger classes that bind to cell surface cell adhesion molecules (CAMs) and ECM ligands. They can be further classified as collagen-binding integrins $\left(\alpha_{1} \beta_{1}, \alpha_{2} \beta_{1}, \alpha_{10} \beta_{1}\right.$, and $\left.\alpha_{11} \beta_{1}\right)$, RGD-recognizing integrins $\left(\alpha_{5} \beta_{1}, \alpha_{V} \beta_{1}, \alpha_{V} \beta_{3}, \alpha_{V} \beta_{5}, \alpha_{V} \beta_{6}, \alpha_{V} \beta_{8}\right.$, and $\left.\alpha_{\mathrm{IIb}} \beta_{3}\right)$, laminin-binding integrins $\left(\alpha_{3} \beta_{1}, \alpha_{6} \beta_{1}, \alpha_{7} \beta_{1}\right.$, and $\left.\alpha_{6} \beta_{4}\right)$, and leukocyte integrins $\left(\alpha_{\mathrm{L}} \beta_{2}\right.$, $\alpha_{M} \beta_{2}, \alpha_{X} \beta_{2}$, and $\left.\alpha_{D} \beta_{2}\right)$. The $\beta_{2}$ integrin subunit (CD18) can pair with one of the four $\alpha$ subunits $\left(\alpha_{L}-C D 11 a, \alpha_{M}-C D 11 b, \alpha_{X}-C D 11 c\right.$, and $\left.\alpha_{D}-C D 11 d\right)$ [16]. The $\alpha 4 \beta 1$ and $\alpha 9 \beta 1$ integrins recognize fibronectin and VCAM- 1 . The $\beta 2$ and $\beta 7$ integrins are restrictedly expressed by leukocytes). Asterisks show the alternatively spliced cytoplasmic domains. This figure is based on the study of Hynes [10] and Yue et al. [17]. (RGD, Arg-Gly-Asp sequence; VCAM-1, a vascular cellular adhesion molecule-11).

\section{Mechanisms of Action of Natural Compounds}

\subsection{Prestimulation with Cytokines}

To demonstrate the inhibitory effect of a natural compound on cellular adhesion, cells, typically from the human umbilical vein endothelial cell line (HUVEC), are usually first treated with certain cytokines to stimulate the expression of CAM (Figure 2). In vivo, lipopolysaccharide (LPS, from Gram-negative bacteria) stimulates the immune response by interacting with its leukocyte membrane receptor, the Pattern Recognition Receptor (PRR) CD14 (with TLR4-MD2), to induce the generation of cytokines such as tumour necrosis factor $\alpha$ (TNF- $\alpha)$, interleukin-1 and -6 (IL-1, IL-6) (Figure 3). TNF- $\alpha$ is also involved in systemic inflammation [2,18]. It is primarily produced by activated monocytes or macrophages [19]. Note, cytokine generation, increase of expression of cytokines can also be stimulated by certain plant extracts (for example, among others, garlic (Allium sativum) decreases the level of IL-1 $\alpha$, IL-2, IL-6, IL-12, TNF- $\alpha$ and IFN- $\gamma$, however, increases IL-10), as summarized by Spelman, et al. [20]. After stimulation of the endothelial cells, the plant 
(or venom) extract is then added to them. The natural compound may downregulate expression of the adhesion molecules, resulting in the diminution of cell adhesion, and the compound has an antiinflammatory effect in consequence. The ICAMs and VCAMs are the most researched adhesion molecules [5]. We elaborate on this in the next section.

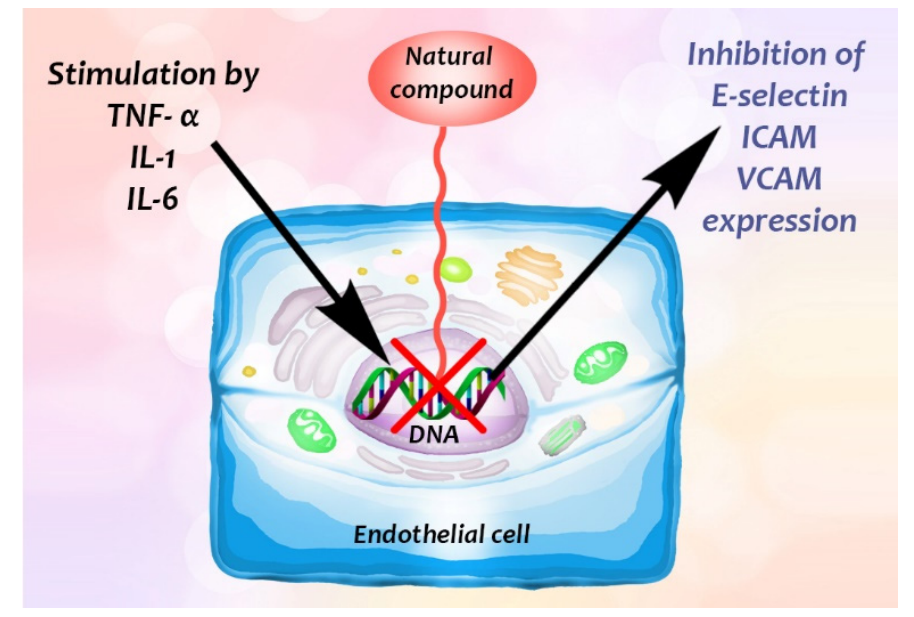

Figure 2. Adhesion molecule stimulation and mechanisms in endothelial cells. Inhibitory effect of a natural compound on cellular adhesion, typically of the human umbilical vein endothelial cell line (HUVEC), which are usually first treated with certain cytokines to stimulate the expression of CAMs.

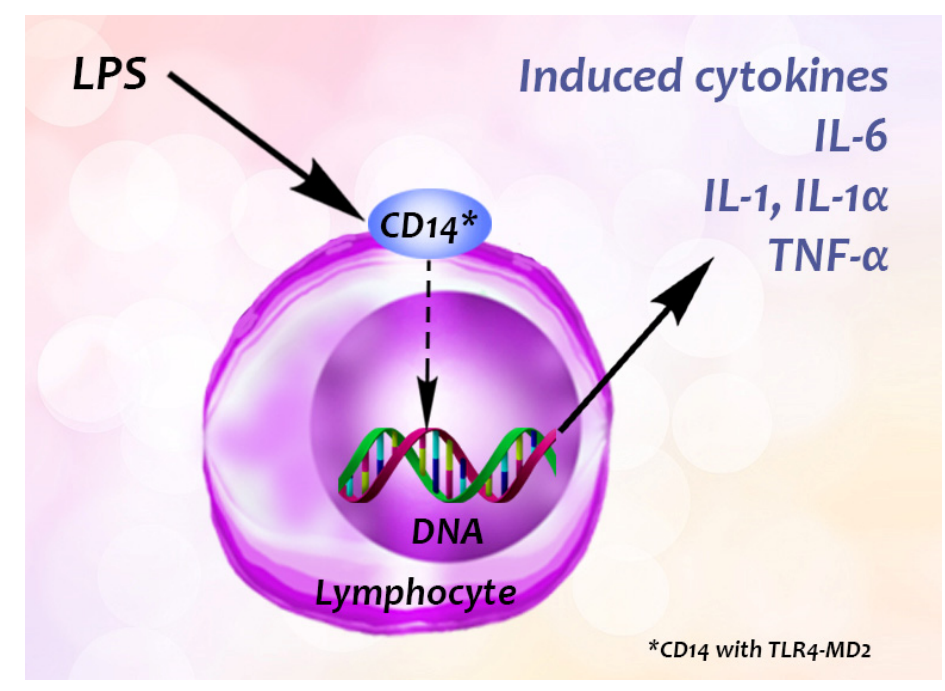

Figure 3. Stimulation mechanism for cytokine modulation in lymphocytes. In vivo, lipopolysaccharide (LPS, from Gram-negative bacteria) stimulates the immune response by interacting with its leukocyte membrane receptor, CD14 (with TLR4-MD2), to induce the generation of cytokines such as TNF- $\alpha$, IL-1, IL-1 $\alpha$, IL-6.

\subsection{Inhibition of CAMs by Suppression of Their Expression (Downregulation)}

The phytochemicals of olive oil (from Olea europaea) and red wine (from Vitis vinifera), oleuropein (monoterpene, seco-iridoid glucoside), hydroxytyrosol (phenylethanoid), tyrosol (phenylethanoid), elenolic acid (monoterpene, seco-iridoid) and resveratrol (stilbene) at nutritionally relevant concentrations have been shown to inhibit endothelial adhesion molecule expression (Figure 2). This provides a strongly suggestive basis for the atheroprotective property of the so-called "Mediterranean diet" [21].

Walnut (Juglans regia) extract and its principal active component ellagic acid decreased the stimulated endothelial expression of ICAM-1 and VCAM-1, indicating a mechanism 
for the known antiatherogenic and osteoblastic activity of the substance [18]. A walnutenriched diet may therefore indeed be cardioprotective and inhibit osteoporosis [18].

Curcumin (diphenylheptanoid) from the Curcuma longa rhizome also downregulated the expression of adhesion molecules and, hence, monocyte adhesion [13]. Saponin (triterpene) astagaloside IV from Mongolian milkvetch (Astagalus membranaceus) decreased the LPS-induced expression of VCAM-1 and E-selectin on the surface of HUVEC, hence this Chinese traditional medicinal herb is predicted to have anti-inflammatory efficacy; however, ICAM-1 was not affected [22].

Tripertygium wilfordii is a vine-like plant that grows in south China, and in the Chinese pharmacopoeia the extract from its root is prescribed for treating long-term rheumatoid arthritis and systemic lupus erytnematosus [7,8]. Chang et al., applied IL- $1 \alpha$ to stimulate HUVEC cells; treatment with a high concentration $(50 \mathrm{ng} / \mathrm{mL}$ ) of the herb extract (containing wilforonide, alkaloids, diterpenes, triterpenes, b-sitosterol, daucosterol, dulcitol and glycosides $[7,23])$ had a significant inhibitory effect on both the expression and secretion of the cellular adhesion molecules, and thus may be a potential therapeutic agent for the treatment of inflammatory diseases [7].

\subsection{Mechanism of Downregulation}

The downregulation of CAMs by natural products is achieved by inhibiting their gene expression.

The molecular details involve the uptake of the natural product by the cytoplasm followed by interaction between the compound and transcription factors for adhesion molecule genes. Activation of the transcription factor nuclear factor $\mathrm{\kappa B}(\mathrm{NF}-\mathrm{kB})$, is mediated by the proinflammatory cytokines mentioned above, for instance TNF- $\alpha$, and triggers gene expression of adhesion molecules (Figure 4). NF- $\mathrm{KB}$ binding sites are found in the promoter region of E-selectin, ICAM-1 and VCAM-1 [13,24-27]. NF- $k B$ is in the cytoplasm in inactive form, complexed to I $\mathrm{B}$ "nuclear factor of $\kappa$ light polypeptide gene enhancer in B-cells inhibitor" [13]. When cells are stimulated with TNF- $\alpha$, the IKB is phosphorylated, ubiquitinated, and degraded. The thereby activated NF- $\mathrm{kB}$ translocates to the nucleus and transcriptionally up-regulates cytokine receptors as well as the adhesion molecules $[13,26,28,29]$.

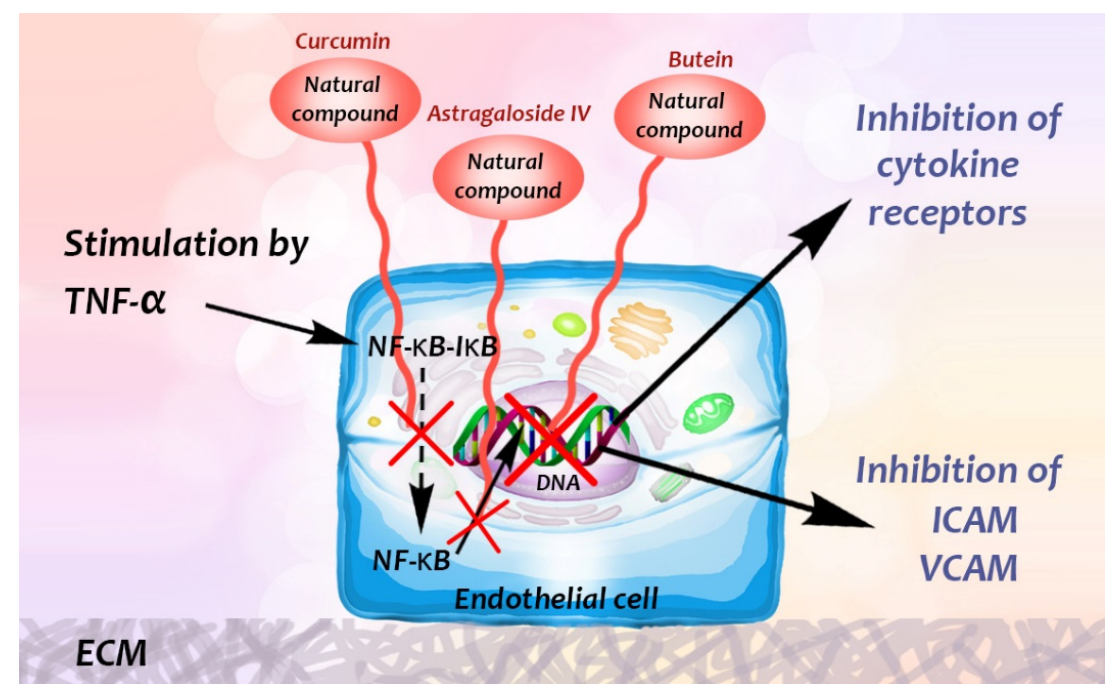

Figure 4. The NF- $\mathrm{kB}$ pathway in endothelial cells. The compounds shown to have anti-inflammatory effects in vivo completely annulled LPS- and TNF- $\alpha$-triggered nuclear translocation of NF- $\mathrm{B}$ and NF- $\kappa B$ DNA-binding activity in endothelial cells, thus the production of cytokine receptors and ICAM, VCAM is inhibited. Table 1.

The expression and function of integrins on various immune cells are summarized in 
Table 1. Ligands and functions of different integrins of human leukocytes (RGD, Arg-Gly-Asp sequence; VCAM-1, vascular cellular adhesion molecule-1; ICAM-1, Intercellular adhesion molecule-1) [10,30-33].

\begin{tabular}{|c|c|c|}
\hline Integrin & Ligands & Functions \\
\hline$\beta 1$ & RGD, VCAM-1, E-cadherin & Adhesion \\
\hline$\beta 2$ & iC3b, fibrinogen, ICAM-1 & $\begin{array}{l}\text { Adhesion, phagocytosis, apoptotic cell } \\
\text { clearance }\end{array}$ \\
\hline$\beta 6$ & RGD, fibronectin & Adhesion, endocytosis, inflammation \\
\hline$\beta 7$ & RGD, VCAM-1 & Adhesion, inflammation \\
\hline
\end{tabular}

Kawasaki and co-workers demonstrated that hot-water extract of Curcuma longa also suppressed the phosphorylation and degradation of $I \kappa B \alpha$ in endothelial cells [13]. Another extract, the triterpene saponin astragaloside IV (3-O- $\beta$-D-xylopyranosyl-6-O- $\beta$-Dglucopyranosylcycloastragenol) from the Chinese herb Astragalus membranaceus, shown to have anti-inflammatory effects in vivo, completely annulled LPS- and TNF- $\alpha$-triggered nuclear translocation of NF- $\mathrm{KB}$ and NF- $\mathrm{KB}$ DNA-binding activity in endothelial cells [22] (Figure 4), furthermore, it has shown that it has antioxidative stress, antiapoptosis, and antifibrosis activities, both in vitro and in vivo [34,35].

Recent studies have shown that astragaloside IV (AS-IV) administration ameliorates diabetic neuropathy in streptozotocin (STZ)-induced diabetic rats via an anti-inflammatory mechanism [36], inhibits endoplasmic reticulum stress [37], and protects podocytes [34,38]. However, the effect and mechanism of AS-IV on diabetic neuropathy induced by type 2 diabetes remain unknown [34]. Flavonoid quercetin attenuates TNF- $\alpha$-induced ICAM-1 and MMP-9 expression in ARPE-19 cells via the MEK1/2-ERK1/2 and PKC $\delta$-JNK1/2c-Jun or NF-kB pathways [39]. Flavonoid apigenin significantly suppressed the TNF$\alpha$-stimulated upregulation of VCAM-1-, ICAM-1-, and E-selectin-mRNA to the basal levels [40]. Simple phenolic compound salicin inhibits IL- $1 \beta$-induced production of proinflammatory cytokines such as TNF- $\alpha$, IL-6, and monocyte chemoattractant protein-1 (MCP-1), vascular adhesion molecules such as (ICAM-1 and VCAM-1, and high-mobility group protein 1 (HMGB-1)) [41].

Lignan-type active compounds manassantin $\mathrm{A}$ and $\mathrm{B}$, dineolignan compounds, inhibited the PMA-induced ICAM-1/LFA-1-mediated homotypic aggregation of the HL-60 cells without cytotoxicity, with MIC values of 1.0 and $5.5 \mathrm{nM}$, respectively. Even though these compounds did not affect the adhesion of ICAM-1 to LFA-1, they inhibited PMA-induced ICAM-1 expression in HL-60 cells in a dose-dependent fashion. These results suggest that manassantin A and B inhibit cell aggregation through downregulation of ICAM-1 expression [42].

HUVECs treated with sesquiterpene $\alpha$-iso-cubebene showed markedly suppressed TNF- $\alpha$-induced mRNA expression of VCAM- 1 and E-selectin, but little alteration in ICAM1 mRNA expression. $\alpha$-iso-cubebene treatment also significantly decreased the TNF$\alpha$-induced cell surface and total protein expression of VCAM-1 and E-selectin without affecting ICAM-1 expression [43].

Diterpene andrographolide significantly reduced E-selectin expression of activated endothelial cells, and inhibited E-selectin expression at the mRNA level [44].

In vitro, triterpene saponine dioscin decreased monocyte adhesion to TNF- $\alpha$-treated HUVECs by reducingvascular cell adhesion molecule-1 (VCAM-1) and intercellular adhesion molecule 1 (ICAM-1) expression and inhibiting endothelial lipase (EL) expression in TNF- $\alpha$-treated HUVECs and macrophages by blocking the NF-kB pathway [45].

Ethyl $3^{\prime}, 4^{\prime}, 5^{\prime}$-trimethoxycinnamate and piperine are the two active principles of Piper longum. Using primary human umbilical vein endothelial cells, Kumar et al. [46] evaluated the activities of ethyl $3^{\prime}, 4^{\prime}, 5^{\prime}$-trimethoxycinnamate on TNF- $\alpha$-induced expression of cell adhesion molecules, ICAM-1, VCAM-1 and E-selectin, which play key roles in controlling 
various inflammatory diseases. Both compounds inhibited the TNF- $\alpha$-induced expression of ICAM-1 [46].

Ganoderma lucidum, a medicinal mushroom, has been used in traditional Chinese medicine to prevent and treat various diseases, for example cancer [47]. A polysaccharide derived from the fungus interacted with cell surface proteins and $\beta 1$-integrin expression was diminished, while $\beta$-actin expression was not affected [47].

We summarize the different modes of pathway intervention involving gene expression in Table 2.

Table 2. Different modes of pathway intervention involving gene expression by natural compounds.

\begin{tabular}{cc}
\hline Mode & Action \\
\hline P1 & Inhibiting the dephosphorylation of $\mathrm{I} \kappa \mathrm{B}$ and, hence, the activation of NF- $\mathrm{kB}$ \\
\hline P2 & Inhibiting translocation of activated NF- $\mathrm{kB}$ into the nucleus \\
\hline P3 & Inhibition of binding of activated NF- $\mathrm{kB}$ to promoter sites for \\
& CAM expression \\
\hline
\end{tabular}

\subsection{Intervention at the ECM}

Flavonoid baicalein, derived from the root of Scutelaria baicalensis, a widely used Chinese herbal medicine that has been used in anti-cancer and anti-inflammatory therapy [48], has an inhibitory effect on the expression of matrix metalloproteinases (MMPs) [48], which are involved in the degradation of the extracellular matrix. Destruction of basement membranes and stromal extracellular matrix is critical for favoring metastasis and invasion of malignant cells [48]. The MMPs have therefore a role in promoting tumour growth, invasion and metastasis. Treatment of human breast carcinoma (MDA-MB-231) cells with baicalein inhibited the expression of MMP-2/9, which is a result of the mitogen-activated protein kinase (MAPK) signaling pathway [48] (Figure 5).

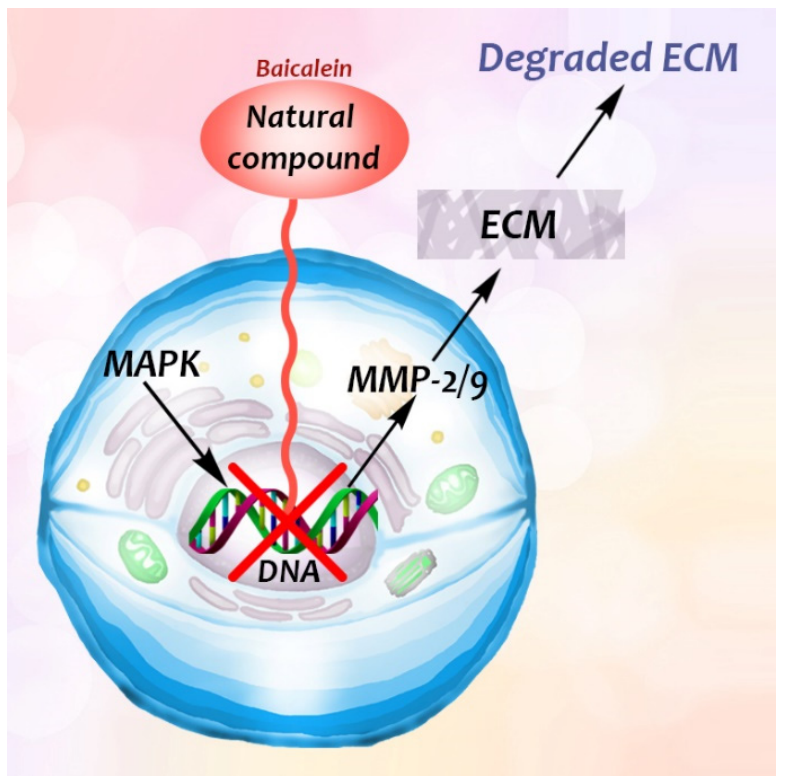

Figure 5. The interaction between the ECM, MMPs and natural compounds in breast carcinoma. Baicalein blocked the expression of MMP-2/9, thus the degradation of the extracellular matrix is also inhibited.

Flavonoid (chalcone) butein (3,3,2' $4^{\prime}$-tetrahydroxychalcone) is an active substance found in several plants, such as Semecarpus anacardium, Dalbergia odorifera, Caragana jubata and Rhus verniciflua [49]. It has been demonstrated that it decreased leukocyte adhesion to A549 
cells through the inhibition of TNF- $\alpha$-induced ICAM-1 and VCAM-1 expression by inhibiting the NF- $\mathrm{BB} / \mathrm{MAPK} / \mathrm{Akt}$ signaling pathway. Butein also inhibits ROS generation [49], and may prevent TNF- $\alpha$-induced airway inflammation [49] (Figure 4).

\subsection{Inhibition of CAM Binding by Blocking Specific Cell-Surface Receptor Sites}

We can distinguish three types of mechanisms inhibiting cell adhesion by blocking (B) specific receptor sites (Table 3).

Table 3. Three types of mechanisms inhibiting cell adhesion by blocking specific receptor sites.

\begin{tabular}{|c|c|}
\hline Mechanism & Action \\
\hline B1 & $\begin{array}{l}\text { Blocking adhesion receptors on the surface of mobile cells (e.g., } \\
\text { leukocytes) }\end{array}$ \\
\hline B2 & $\begin{array}{l}\begin{array}{l}\text { Blocking adhesion receptors on the surface of tissue cells (e.g., of the } \\
\text { endothelium) }\end{array}\end{array}$ \\
\hline B3 & Blocking adhesion motifs in the extracellular matrix (ECM) \\
\hline
\end{tabular}

In contrast to intervention at the level of protein expression, natural compounds can also specifically block cell recognition motifs, such as the amino acid triplet RGD. For example, the polyphenol EGCG from green tea has been shown to block RGD motifs (B) (Arg-Gly-Asp) and, hence, inhibit adhesion [50].

We recall that integrins are transmembrane heterodimers, a family of plasma membrane receptors that mediate adhesion of leukocytes to ECM [51]. Integrins are also involved in pathophysiological processes as well, such as genetic and autoimmune diseases, metastasis and thrombosis and, thus, integrins are important therapeutic target structures [51,52]. Blocking or disruption of binding to integrin receptors is therefore an important topic in industrial drug discovery [51,53]. Serpent venom disintegrins, a family of low molecular weight proteins, typically contain the RGD motif, and are known to block integrin activities by binding with high affinity to the integrins $[51,54]$. For example, rhodostomin, a snake venom from Calloselasma rhodostoma, blocked the integrin $\alpha v \beta 3$ and also affected pp125 FAK phosphorylation and the actin cytoskeleton [55]. Rhodostomin contains an RGD motif that specifically inhibits the integrin-binding function [56]. It can be produced in Pichia pastoris (methylotrophic yeast) as well and it inhibits platelet aggregation with a $K(\mathrm{I})$ of $78 \mathrm{nM}$ as potent as native rhodostomin [56]. However, its D51E mutant blocks platelet aggregation with a $K(\mathrm{I})$ of $49 \mathrm{mM}$ [56]. Structural analysis of rhodostomin and its D51E mutant showed that they have the same tertiary fold with three two-stranded antiparallel beta-sheets [56]. Two minor differences between them were inferred from their backbone dynamics and 3D structures [56]. The docking of rhodostomin into integrin $\alpha \mathrm{Ilb} \beta 3$ showed that between the backbone amide and carbonyl groups of the D51 residue were formed hydrogen bonds with the integrin residues R216 and R214, respectively [56]. In contrast, these hydrogen bonds were absent in the D51E mutant-integrin complex [56].

Another serpent venom, echistatin from Echis carinatus, inhibited integrin-mediated cell adhesion via selective recognition by $\alpha \operatorname{Ilb} \beta 3, \alpha 5 \beta 1, \alpha \vee \beta 3$ integrins [51], preventing their adhesion to the ECM.

Not only snake venom affects integrin-mediated adhesion, but herbs as well. Epigallocatechin-gallate (EGCG) (flavonoid ester) is the main polyphenol of green tea (Camellia sinensis). Many studies have shown its beneficial effect on human health [1]. The majority of them demonstrated direct effects on cell adhesion and movement. In a previous study we showed that EGCG indirectly affects HeLa cell adhesion: the cells cannot adhere onto EGCG-pre-treated model ECM coatings [50]. The polyphenol formed multilayers in poly-L-lysine polyethylene-glycol-RGD (PLL-g-PEG-RGD) chains, and blocked the RGD motifs [50]. EGCG alters the properties of mucin as well; EGCG-mucin mixtures showed that discrete particles are formed and their size increases with the ratio of EGCG to mucin [57]. Another natural compound, cistifolin 
(benzofuran derivative) from the rhizome of the gravel root (Eupatorium purpureum), known as an anti-rheumatic herbal drug, was identified as a potent inhibitor of $\beta 1$ and $\beta 2$ integrin-mediated cell adhesion and, thus, has therapeutic potential for diseases where integrin adhesion molecules play a significant role [58].

\section{Measurement Techniques for Monitoring Cellular Functions, Adhesion and Viability \\ 4.1. Classical Techniques for Measuring Cell Viability}

Experimental natural compounds are added to stimulated cell cultures to induce a CAM response, which is commonly measured by labeling methods, mainly the enzymelinked immunosorbent assay (ELISA), Western blot, and flow cytometry. ELISA uses antibodies linked to enzymes that create a color change (e.g., by altering a dye) to identify the examined substances [13]. The Western blot is a widely used technique in biology to detect specific proteins in a sample by letting animal-derived or synthetic antibodies bind to them [13]. ELISA and Western blot techniques cannot be used for measuring cell viability directly; however, for example, Western blot can be applied as a complementary method to study the mechanism of cell death (apoptosis, autophagy markers, etc.), thus it provides a lot of information about the mechanism. Flow cytometry is usually a laser-based technique for cell sorting and counting. A wide range of fluorophores can be used in flow cytometry measurements. Fluorophores are fluorescent labels that can attach to the antibody that recognizes the target molecule of the cell [2,59]. However, impedance-based flow cytometers also exist, known as Coulter counters, which are well established label-free methods for sizing and counting cells and particles [60].

Some workers have used staining to reveal the effect of natural compounds on cell viability, mainly the MTT (3-(4,5-dimethylthiazol-2-yl)-2,5-diphenyltetrazolium bromide) assay and the trypan blue exclusion test. However, Wang et al. in 2010 showed that the MTTand MTS (3-(4,5-dimethylthiazol-2-yl)-5-(3-carboxymethoxyphenyl)-2-(4-sulfophenyl)-2Htetrazolium)-based assays (Figure 6) underestimate the antiproliferative effect of EGCG [1,61].

The terms "cell viability" or "compound cytotoxicity" have broad meanings in drug discovery. For in vitro monolayer cell cultures, a compound is considered to be cytotoxic if the compound interferes with cellular attachment, or significantly alters cellular morphology, cell growth and cell viability. A variety of assay methods can be used to estimate the number of viable eukaryotic cells after exposure of the investigated compounds. These cell-based assays are often used for screening collections of compounds to determine if the compounds have effects on cell proliferation or show cytotoxic and cytostatic effects. Cell-based assays are also widely used for monitoring organelle function. These screening methods have been devised to examine a broad variety of parameters associated with biochemical events necessary for sustaining viability, especially as evinced by membrane integrity. The quantities emerging from metabolism (especially ATP-based viability) assays are proportional to viable cell number. Cytotoxicity assays determine parameters proportional to the degree of cell death. The fundamental difference between the approaches depends on the length of exposure to the compound (short-term exposures ( $4 \mathrm{~h}$ or less) may adversely affect metabolism markers or ATP content before measurable membrane integrity changes, and long-term exposures ( $24 \mathrm{~h}$ or more), particularly after early primary necrosis, may lead to underestimation of cytotoxicity owing to degradation of marker enzyme activity after its release into the extracellular environment [62-65].

Most cell viability and cytotoxicity assays can be divided into three categories: those that (i) exploit the loss of membrane integrity; (ii) directly measure metabolic markers or ATP content; and (iii) assess metabolic activity. Other forms of detection exist. Crystal violet staining can reveal the adherence of cells and thus be used to measure the viability of adherent cells [66-68]. Determination of the loss of membrane integrity: these assays rely on the breakdown/disintegration of the cell membrane to allow different molecules to enter the cell, or allow intracellular compounds to be secreted to the extracellular area. 


\section{A FLOW CYTOMETRY}
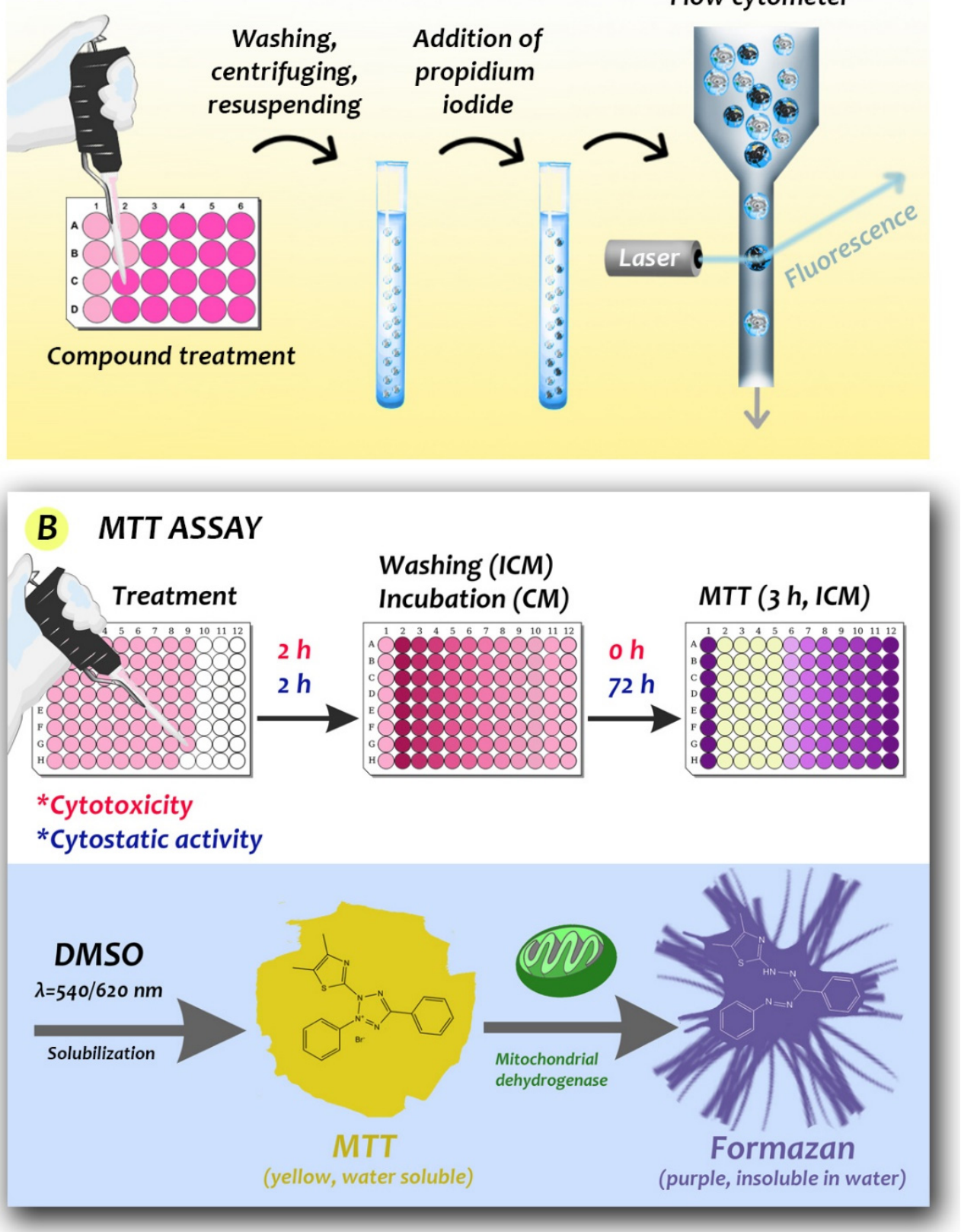

Figure 6. Schematic illustration of the measurement steps of flow cytometry (A) and tetrazoliumbased colorimetric MTT viability tests (B). (A) Propidium iodide is a popular red-fluorescent counterstain. Living cells are not permeable to it, but dead cells are (hence acquire dark coloring) and can be detected in the population after exposure treatment of the cells. (B) The basis of the MTT assay is that the yellow, water-soluble tetrazole becomes purple, insoluble formazan by the action of mitochondrial dehydrogenase of living cells. Cytotoxic and cytostatic activities can be determined from the optical density of the control and treated cells (ICM: incomplete medium, CM: complete medium). The formazan can be conveniently extracted by DMSO for colorimetric measurement.

Metabolic assays primarily focus on measuring ATP levels, or the reduction of tetrazolium salts, or resazurin dyes inside living cells.

Cellular proliferation causes a change in the ratios of certain metabolites e.g., NADPH/ NADP, FADH/FAD, FMNH/FMN, and NADH/NAD. These metabolic intermediates are then capable of reducing tetrazolium salts to formazan product, which can be detected. 
Resazurin (7-hydroxy-3H-phenoxazin-3-one 10-oxide) is a non-fluorescent redox dye, which when reduced to resorufin becomes a red compound, so the color change can be detected.

The most common method for assaying live cell proliferation is measuring the amount of DNA synthesis, which is done by adding a labeled DNA analog called BrdU (5-bromo-2'deoxyuridine (BrdU), which is incorporated into the DNA instead of thymidine. To assess the incorporation of BrdU into the DNA colorimetric ELISA or immunohistochemical staining methods are used. A newer approach is to detect the incorporation of the alkyne containing thymidine analog EdU. The incorporation can be detected by a copper catalyzed azide-alkyne cycloaddition.

\subsection{Limitations and Considerations When Using Membrane Integrity or Metabolic Assays}

The listed substrates (Tables 4-7) all have distinct advantages and disadvantages when compared to each other. Assay sensitivity, noise-to-signal ratio, ease of use, and also reagent stability are all factors that have to be considered. Metabolic assays also need to consider that the reduction of said substrates are impacted by other intracellular metabolic activity, and have no direct effect on the cells viability or cytotoxicity of a studied compound.

In fixed samples such as animal tissues and cell population, proliferation can still be measured, but only by immunostaining for specific proliferative markers. Ki-67 is a nuclear protein that is associated with cell proliferation and ribosomal RNA transcription. Traditional antibodies for Ki-67 can only be used to stain frozen (not paraffin embedded) samples. MIB-1 antibodies however target a different epitope of Ki-67, and thus can be used to stain formalin and paraffin fixed samples, making the use of Ki-67 as a proliferative marker easier. Another commonly used marker is the proliferating cell nuclear antigen. This protein expedites DNA synthesis by holding the polymerase to the DNA, so it is expressed widely in the nucleus during DNA synthesis, making it an effective marker of cell proliferation. Other markers that can be used include MCM2 also. It has to be noted that all such assays measuring DNA synthesis directly or indirectly are sensitive to the stage of the cell in the cell cycle at the time the measurement is carried out. 
Table 4. Absorbance-based and colorimetric cell viability and cytotoxicity assays ${ }^{1}$.

\begin{tabular}{|c|c|c|c|c|c|}
\hline \multicolumn{6}{|c|}{$\begin{array}{l}\text { Cell Viability and Cytotoxicity Assays } \\
\text { Absorbance-Based or Colorimetric }\end{array}$} \\
\hline & & Principal & Advantage & Disadvantage & References \\
\hline \multirow{2}{*}{ 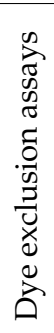 } & Trypan blue & membrane integrity & simple, easy to use, economic, fast & $\begin{array}{l}\text { hemocytometer required, counting } \\
\text { error, difficult to process large } \\
\text { number of samples, cannot be } \\
\text { distinguished healthy cells and cell } \\
\text { function lost alive cells, toxic on } \\
\text { mammalian cells }\end{array}$ & $\begin{array}{c}\text { Jonston } 2010 \text { [69], } \\
\text { Strober 2001 [70], } \\
\text { Aslantürk and Celik 2013 [71], } \\
\text { Stone et al., 2009 [72], } \\
\text { Yip and Auersperg 1972 [73], } \\
\text { Ruben 1988 [74] }\end{array}$ \\
\hline & $\begin{array}{c}\text { Eosin } \\
\text { (Erythrosin B) }\end{array}$ & membrane integrity & economic, versatility, biosafety & $\begin{array}{l}\text { time-consuming, labor-intensive, } \\
\text { sensitive for the contamination, } \\
\text { filling rate, and inter-user variation }\end{array}$ & $\begin{array}{l}\text { Kim et al., } 2016 \text { [75], } \\
\text { Marmion } 1979 \text { [76] }\end{array}$ \\
\hline \multirow{5}{*}{ 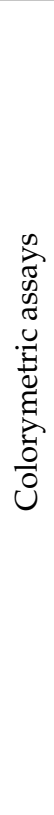 } & MTT & \multirow{5}{*}{$\begin{array}{l}\text { enzyme (mitochondrial) } \\
\text { activity }\end{array}$} & $\begin{array}{l}\text { easy to use, safe, high } \\
\text { reproductibility, widly used }\end{array}$ & $\begin{array}{c}\text { organic solvents required, significant } \\
\text { well-to-well error, interaction with } \\
\text { compounds results false positive, or } \\
\text { false negative data }\end{array}$ & $\begin{array}{c}\text { Stone et al., } 2009 \text { [72], } \\
\text { Aslantürk et al. [77], } \\
\text { Bopp and Lettieri 2008 [78], } \\
\text { Mosmann } 1983 \text { [79] }\end{array}$ \\
\hline & MTS & & $\begin{array}{l}\text { easy to use, rapid, sensitive, } \\
\text { economic, specific, inexpensive }\end{array}$ & $\begin{array}{l}\text { measured absorbance level is } \\
\text { influenced by incubation time, cell } \\
\text { type, and cell number; optimal } \\
\text { incubation time: } 1-3 \mathrm{~h}\end{array}$ & $\begin{array}{c}\text { Berg et al., } 1994 \text { [80], } \\
\text { Tominaga et al., } 1999 \text { [81], } \\
\text { Rotter et al., } 1993 \text { [82], } \\
\text { Buttke et al., } 1993 \text { [83], } \\
\text { Promega Technical Bulletin [84] } \\
\text { Cory et al., } 1991 \text { [85], } \\
\text { Riss et al., } 1992 \text { [86] }\end{array}$ \\
\hline & XTT & & $\begin{array}{l}\text { results water soluble crystals, quick, } \\
\text { sensitive, easy-to-use, safe; highly } \\
\text { sensitive and accurate }\end{array}$ & $\begin{array}{l}\text { strongly depends on reductive } \\
\text { capacity of viable cells due to } \mathrm{pH}, \\
\text { cellular ion concentration, cell cycle } \\
\text { variation, environmental factors }\end{array}$ & Scudiero et al.1988 [87] \\
\hline & WST-1 & & $\begin{array}{l}\text { easy to use, high reproducibility, } \\
\text { wildly used, no interference with } \\
\text { phenol red, water soluble dye, no } \\
\text { additional incubation time }\end{array}$ & relatively long incubation time $(2 \mathrm{~h})$ & Ishiyama et al., 1993 [88] \\
\hline & WST-8 & & $\begin{array}{l}\text { not cell permeable; cells can be used } \\
\text { after the assay; water soluble } \\
\text { formazan }\end{array}$ & $\begin{array}{l}\text { intracellular metabolic activity can } \\
\text { influence the reduction of WST- } 8\end{array}$ & $\begin{array}{l}\text { Tominaga et al., } 1999 \text { [81], } \\
\text { Strober } 2001 \text { [70] }\end{array}$ \\
\hline
\end{tabular}


Table 4. Cont.

\section{Cell Viability and Cytotoxicity Assays}

Absorbance-Based or Colorimetric

\section{Advantage}

enzyme (lactate

LDH (lactate dehydrogenase)

dehydrogenase) activity

SRB (sulforhodamine B) SRB-protein interaction

NRU (neutral red uptake)

neutral red uptake and

lysosomal accumulation

reliability; quick, simple evaluation, indicator of cell death

\section{simple, fast, sensitive, good linearity}

with cell number, metabolism

independent, high reproducibility

good marker for lysosomal damage fast and simple evaluation
Principal

Disadvantage

serum incompetence

binding for proteins and DNA of viable cells quick; chemical inhibtors can be incorporated into the assay homogenous cell suspension is required; cellular clumps and aggregates interfere with SRB

influenced by pollutants
References

Decker and Lohmann-Matthes 1988 [89],

Schins et al., 2002 [90]

Fotakis et al., 2006 [91]

Lappalanien et al., 1994 [92]

Skehan et al., 1990 [93]

Borenfreund and Puerne

Repetto et al., 2008 [95],

Ringwood et al.1998 [96]

Feoktisova et al., 2016 [66], Geserick et al., 2009 [97] Sun Sun et al., 2012 [99], Feoktisova et al., 2011 [100]
Crystal viole metabolism affected compounds can not be tested, not able to measure cell proliferation rate

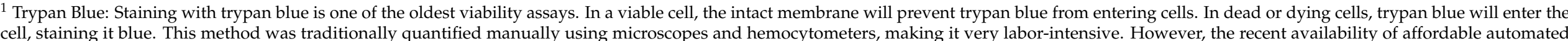

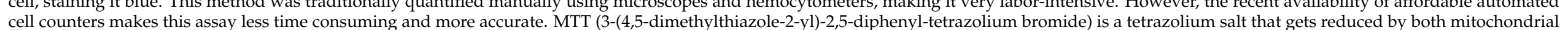

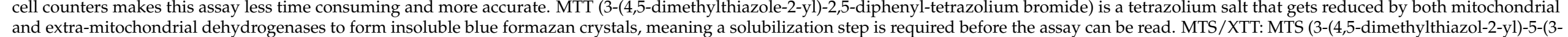

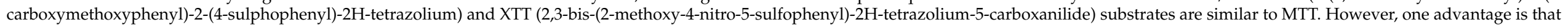

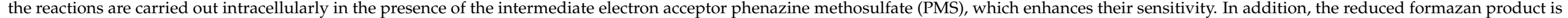

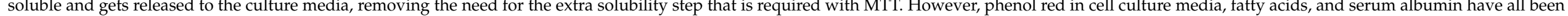

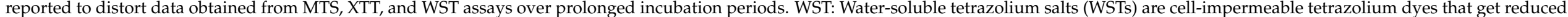

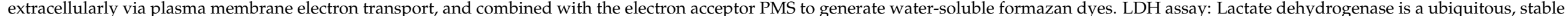
cytoplasmic enzyme that converts lactate to pyruvate. If the cell membrane has been damaged, LDH, and therefore, its enzymatic activity is released from cells and can be detected in cell culture media.
} 
Table 5. Fluorometric cell viability and cytotoxicity assays ${ }^{1}$.

\begin{tabular}{|c|c|c|c|c|}
\hline \multicolumn{5}{|c|}{ Fluorometric Assay } \\
\hline & Principal & Advantage & Disadvantage & References \\
\hline AlamarBlue (resazurin reduction assay) & $\begin{array}{l}\text { enzyme (mitochondrial and other (e.g., } \\
\text { Diaphorases)) activity }\end{array}$ & $\begin{array}{l}\text { relatively inexpensive, sensitive, } \\
\text { multiplexed with other methods (e.g., } \\
\text { Caspase activity) }\end{array}$ & $\begin{array}{l}\text { fluorescence interference with tested } \\
\text { compound; direct cytotoxic effect can be } \\
\text { occured (depending on incubation time) }\end{array}$ & $\begin{array}{l}\text { O'Brien et al., } 2000 \text { [101], } \\
\text { Ahmed et al., } 1994 \text { [102], } \\
\text { Page et al., 1993 [103], } \\
\text { Markossian et al.., } 2004 \text { [65], } \\
\text { Pace et al., } 2013 \text { [104] }\end{array}$ \\
\hline $\begin{array}{l}\text { CFDA-AM (5-carboxyfluorescein } \\
\text { diacetate, acetoxymethyl ester) }\end{array}$ & plasma membrane integrity & $\begin{array}{l}\text { can be used parallel with alamarBlue on } \\
\text { the same set of cells }\end{array}$ & $\begin{array}{l}\text { fluorescence interference with tested } \\
\text { compound }\end{array}$ & $\begin{array}{l}\text { Bopp et al., } 2006 \text { [103], } \\
\text { Schreer et al., } 2005 \text { [105], } \\
\text { Ganassi } 2000 \text { [106] }\end{array}$ \\
\hline $\begin{array}{l}\text { protease viability marker assay; } \\
\text { GF-AFC assay (glycylphenyl-alaninyl)- } \\
\text { aminofluoro-cumarine) }\end{array}$ & enzyme (aminopeptidase) activity & $\begin{array}{l}\text { relatively nontoxic; multiplex with other } \\
\text { assays, short incubation time ( } 30-60 \mathrm{~min} \text { ) }\end{array}$ & $\begin{array}{l}\text { fluorescence interference with tested } \\
\text { compound }\end{array}$ & Niles et al., 2009 [62] \\
\hline $\begin{array}{c}\text { BrdU } \\
\text { (bromoeoxyuridin) and EdU } \\
\text { (5-ethynyl-2 deoxyuridine) }\end{array}$ & DNA synthesis & $\begin{array}{l}\text { rapid, highly selective, results in the } \\
\text { most reliable and direct index of } \\
\text { proliferation, in contrast to } \\
{ }^{3} \mathrm{H} \text {-thymidine incorporation assay, } \\
\text { which requires a scintillation } \\
\text { beta-counter, BrdU and EdU can be } \\
\text { detected by antibodies, allowing analysis } \\
\text { by flow cytometry or by } \\
\text { immuno-histochemistry }\end{array}$ & $\begin{array}{l}\text { BrdU is toxic and mutagenic, alters cell } \\
\text { cycle, required DNA denaturation }\end{array}$ & $\begin{array}{c}\text { Sidman et al., 1959 [107] } \\
\text { Miller and Nowakowski 1988 [108] } \\
\text { Salic and Mitchison } 2008 \text { [109] } \\
\text { Nowakowski et al., } 1989 \text { [110] } \\
\text { Taupin 2007 [111] } \\
\text { P.L } \\
\text { Duque and Rakic 2011 [112] }\end{array}$ \\
\hline
\end{tabular}

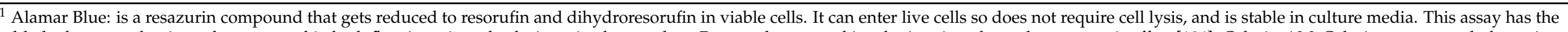

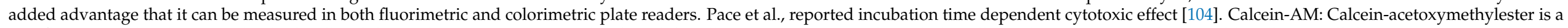

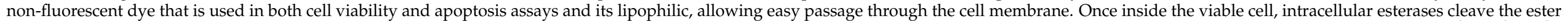

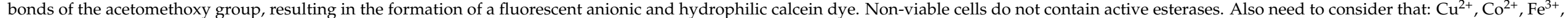
$\mathrm{Mn}^{2+}$, and $\mathrm{Ni}^{2+}$ quench the fluorescent signal from calcein at physiological $\mathrm{pH}$, which means care must be taken to select the appropriate cell culture media. 
Table 6. Luminometric cell viability and cell cytotoxicity assays ${ }^{1}$.

\begin{tabular}{|c|c|c|c|c|c|}
\hline \multicolumn{6}{|c|}{ Luminometric Assay } \\
\hline & & Principal & Advantage & Disadvantage & References \\
\hline \multicolumn{2}{|c|}{ ATP assay } & membrane integrity & $\begin{array}{l}\text { the fastest and the most sensitive } \\
\text { assay to use; no artefacts; no } \\
\text { plate handling step }\end{array}$ & $\begin{array}{l}\text { sensitivity depends on } \\
\text { reproducibility of pipetting }\end{array}$ & $\begin{array}{l}\text { Maehara et al., } 1987 \text { [113], } \\
\text { García et al., } 2003 \text { [114], } \\
\text { Andreotti et al., [115], } \\
\text { Markossian et al., } 2004 \text { [65] }\end{array}$ \\
\hline \multicolumn{2}{|c|}{ Real-time viability assay } & metabolic activity & $\begin{array}{l}\text { real-time measurement; } \\
\text { multiplex }\end{array}$ & $\begin{array}{l}\text { incubation time is cell type and } \\
\text { seeding density dependent }\end{array}$ & $\begin{array}{l}\text { Duellman et al., } 2015 \text { [116], } \\
\text { Markossian et al., } 2004 \text { [65] }\end{array}$ \\
\hline \multicolumn{6}{|c|}{$\begin{array}{l}{ }^{1} \text { ATP content: there are numerously available assays that measure ATP levels as an output, when cells begin to undergo cell death process (apoptos } \\
\text { through the activity of ATPases that concurrently prevent any new ATP synthesis. This leads to a rapid depletion of intracellular ATP levels. Lumines } \\
\text { while concurrently inhibiting ATPases. Luciferase catalyzes the oxidation of luciferin to oxyluciferin in the presence of magnesium and ATP, resul } \\
\text { intracellular ATP concentration. }\end{array}$} \\
\hline \multicolumn{6}{|c|}{ Table 7. Cell viability assays for flow cytometry and microscopic imaging ${ }^{1}}$. \\
\hline \multicolumn{6}{|c|}{ Cell Viability Assays for Flow Cytometry and Microscopic Imaging } \\
\hline \multirow{4}{*}{ 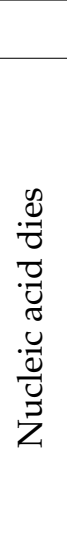 } & & $\lambda$ ex & Advantage & Disadvantage & References \\
\hline & Propidium iodide & 488 and $561 \mathrm{~nm}$ & $\begin{array}{l}\text { can be added directly to the } \\
\text { samples }\end{array}$ & $\begin{array}{c}\text { not membrane permeable to live } \\
\text { cells, not possible to use on fixed } \\
\text { cells, can also bind to RNA not } \\
\text { only to DNA, toxigenic and } \\
\text { mutagenic }\end{array}$ & Suzuki et al., 1997 [117] \\
\hline & $\begin{array}{l}\text { 7-amino-actinomycin-D } \\
\text { (7-AAD) }\end{array}$ & 488 and $561 \mathrm{~nm}$ & $\begin{array}{l}\text { can be added directly to the } \\
\text { samples, can be used in } \\
\text { combination with formaldehyde } \\
\text { fixation }\end{array}$ & $\begin{array}{l}\text { not membrane permeable to live } \\
\text { cells, potential carcinogen }\end{array}$ & $\begin{array}{l}\text { Liu et al., } 1991 \text { [118] } \\
\text { Latt 1977 [119] }\end{array}$ \\
\hline & Hoechst 33342 & 350 and $454 \mathrm{~nm}$ & & $\begin{array}{l}\text { not membrane permeable to live } \\
\text { cells }\end{array}$ & $\begin{array}{l}\text { Liu et al., } 2019 \text { [120], } \\
\text { Réu et al., } 2019 \text { [121] }\end{array}$ \\
\hline
\end{tabular}


Table 7. Cont.

\section{Cell Viability Assays for Flow Cytometry and Microscopic Imaging}

$\lambda e x$ Advantage

it can also be used for viability in

microscopy on live cells or as a

nuclear counterstain on fixed and

permeabilized cells and tissue

sensitive nucleic acid stain, in

Helix NPTM Green, NIR and

Blue

wide range from 444-640 nm and SYTOX ${ }^{\circledR}$ based dyes used, works with mammalian and Gram-positive and Gram-negative non cell-permeable to live cells bacteria, can be incorporated

SYTOX ${ }^{\circledR}$ stains into a number of assays for apoptosis, cell viability,

and metabolism, easy-to-use.

can be combined with FITC, PE, and other UV or violet excitable dyes for multicolor analysis, non toxic, can be used for siRNA studies and other dynamic viablity assays

far-red fluorescent DNA dye

$633 \mathrm{~nm}$

$518 \mathrm{~nm}$

$494 \mathrm{~nm}$

SYBR $^{\circledR}$ Green not membrane-permeable to live

cells

not membrane-permeable intercalates double-stranded DNA and RNA, mutagen, carcinogen,

carcinogen, less mutagenic than ethidium bromide can be used on fixed cells, economi with propidium
Disadvantage

References

Avlasevich et al., 2006 [122]

Yan et al., 2000 [123],

Bryce et al., 2007 [124],

Mukhopadhyay et al., 2007 [125]
Kerscher et al., 2019 [126]

Paivandy et al., 2019 [127]

Vig et al., 2019 [128]

Akagi et al., 2013 [129]

Severini and Morgan 1991 [130]

cell permeable, low-cost, sensitive,

rapid, intercalate to $\mathrm{DNA}$, and

electrostatically interact with RNA

Acridine orange

$500 \mathrm{~nm}$

be also detected, compatible for

nonfixable

Zipper et al., 2004 [131]

Singer et al., 1999 [132]

ethidium bromide and propidium

iodide 
Table 7. Cont

\section{Cell Viability Assays for Flow Cytometry and Microscopic Imaging}

traditional organic fluorescence dies,

multiple application, fully

References
eFluor fixable dyes

wide range from $401-645 \mathrm{~nm}$
Disadvantage

Lekishvili et al., 2018 [136]

BD Biosciences products [137]

Pardo-Garcia et al., 2015 [138],

McMaster et al., 2015 [139],

Rodríguez- Rodríguez et al., 2015

$$
\text { [140], }
$$

Files et al., 2015 [141],

kabane et al., 2016 [142],

Iraolagoitia et al., 2016 [143]

Mercer et al., 2016 [144],

Biolegend Zombie dyes wide range from 360-633 nm
Souza-Fonseca-Guimaraes et al.

$$
2015 \text { [145], }
$$

Matsui et al., 2015 [146]

Jones et al., 2015 [147],

Nath et al., 2015 [148]

Kanemaru et al., 2015 [149]

Tabalot-Ayer et al., 2015 [150],

Keppel et al., 2015 [151]

Shade et al., 2015 [152],

Weiser et al., 2015 [153] 
Table 7. Cont.

Cell Viability Assays for Flow Cytometry and Microscopic Imaging

$\lambda e x$ Advantage
Disadvantage

References

cell permeant, indicator of lipid

vesicle leakage, neutral substrate for

MDR efflux transporters, selective

for live cells; suitable for

proliferating and non-proliferating

cells; ideal for suspension and

adherent cells, rapid, ideal for

high-throughput assays; commonly

used for cell tracing and in studies of

endocytosis, cell migration, and gap

junctions; adaptable to a wide variety

of techniques, including: microplate

assays, immunocytochemistry, flow

cytometry, and in vivo cell tracking
Allen and Cleland 1980 [154]

Patel et al., 2009 [155],

Glavinas et al., 2004 [156]

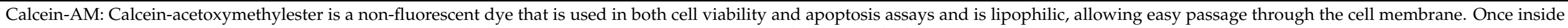

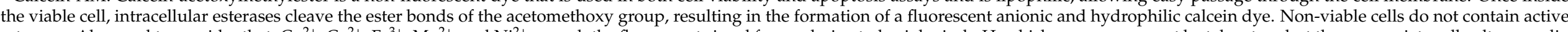

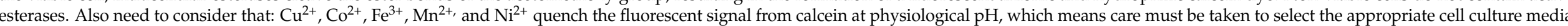

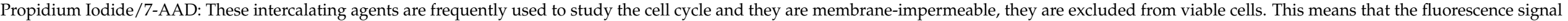

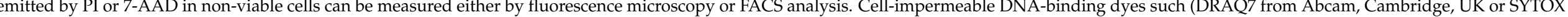
from Thermo Fisher, Waltham, MA, USA) enter cells through compromised cell membranes and display strong fluorescence upon binding with DNA.
} 
The most frequently used techniques in cellular adhesion experiments with natural compounds are based on dyes (absorbing or fluorescing) as labels. These methods have several drawbacks; however, (i) in general they are not high-throughput techniques, since the procedures are time-consuming and complicated, (ii) many dyes are cytotoxic and therefore disturb the normal physiological activity of the cells; furthermore their structures are often quite comparable to those of the natural compounds under investigation, leading to interference, (iii) typically only end-point data is gathered; i.e., no information on the kinetics of the processes is obtained, (iv) many natural compounds investigated for possible therapeutic benefits have low molecular weight, and frequently are environmentally sensitive (e.g., to oxidation) and thermally or photolytically unstable.

A good example of this instability is the green tea polyphenol EGCG [1,50]. Investigating the physiological effects of such compounds by labeling techniques exacerbates the difficulties.

Recent developments, such as the use of quantum dots (semiconductor nanoparticles) and gold nanoparticles instead of organic dyes as labels do little to alleviate these disadvantages.

\subsection{Measurement Techniques for Monitoring Cellular Movement and Adhesion}

Cell migration takes place inside or on the extracellular matrix surface [157]. The lamellae of the cell have to adhere to the matrix components to generate traction forces for cell movement [157]. The actin filaments of the cytoskeleton are linked through the cell membrane to the substrate at focal adhesion points, which are connected by actin filaments such as to promote the direction of movement and are located under the entire body of the cell $[157,158]$. Hence, adhesion and migration are in close relation to each other; adhesion is essential to achieve cellular movement. Thus, measuring cell migration with migration assays provides information about cell adhesion as well [157]. In Table 8, we summarize the advantages and disadvantages of migration assays. Spreading and adhesion play crucial roles in development and maintenance of cell homeostasis and in many further complex functional processes [159,160]. Many types of assays have been developed to measure the adhesion strengths (forces) and can be categorized into single cell and population cell studies [158,161,162]. Cell adhesion detachment events for single cell studies can be initiated via the breakage of molecular bonds (e.g., optical tweezer techniques and micropipette aspiration), cell population studies via static adhesion (centrifugation technique), and cell population studies via dynamic adhesion (e.g., microfluidic techniques, spinning disk, and flow chamber) $[158,161,162]$. The measurement of migration and adhesion under experimental in vitro conditions can provide important information about natural compounds, yielding quantitative data about cellular movement and adhesion albeit in a drastically simplified environment compared to the in vivo situation [50]. 
Table 8. Conventional assay systems to quantify cell migration.

\begin{tabular}{|c|c|c|c|c|}
\hline \multicolumn{5}{|c|}{ Migration Assays } \\
\hline & Principal & Advantage & Disadvantage & References \\
\hline $\begin{array}{l}\text { Transwell migration and invasion assay } \\
\text { (Boyden chamber) }\end{array}$ & chemotaxis, migration, invasion & $\begin{array}{c}\text { easy setup, most frequently used } \\
\text { method, can be visualized by cytological } \\
\text { dyes, } \\
\text { stained fluorescent, or lysed and } \\
\text { assessed by a plate reader; invasive } \\
\text { index can be calculated }\end{array}$ & $\begin{array}{l}\text { endpoint measurement, only adherent } \\
\text { cells can be used, only vertical } \\
\text { movement can be detected, must be } \\
\text { optimized for each cell type }\end{array}$ & $\begin{array}{l}\text { Menyhárt et al., } 2016 \text { [64], } \\
\text { Kramer et al., } 2013 \text { [163], } \\
\text { Boyden } 1962 \text { [164], } \\
\text { Restouin et al., 2009 [165], } \\
\text { Marshall 2011 [166] }\end{array}$ \\
\hline Scratch (wound healing) assay & $\begin{array}{l}\text { two dimensional (2D) cell migration in } \\
\text { confluent, monolayer cell cultures }\end{array}$ & $\begin{array}{l}\text { simple, easy setup, low cost, kinetic } \\
\text { measurement, can be combined with } \\
\text { other techniques (e.g., gene } \\
\text { transfections), allows high -throughput } \\
\text { screening (HTS) }\end{array}$ & $\begin{array}{l}\text { only adherent cells can be used, only } \\
\text { horizontal movement can be detected, } \\
\text { require relatively large cell and reagent } \\
\text { quantities, is not ideal for chemotaxis } \\
\text { studies }\end{array}$ & $\begin{array}{c}\text { Menyhárt et al., } 2016 \text { [64], } \\
\text { Liang et al., } 2007 \text { [167], } \\
\text { Győrffy et al., } 2015 \text { [168], } \\
\text { Gorshkova et al., } 2008 \text { [169], } \\
\text { Lo et al., 1995 [170], } \\
\text { Tamada 2007 [171], } \\
\text { Zordan et al., } 2011 \text { [172], } \\
\text { Poujade et al., } 2007 \text { [173], } \\
\text { Simpson et al., } 2008 \text { [174] }\end{array}$ \\
\hline Cell exclusion zone assays & migration & $\begin{array}{l}\text { Several kinds of barrier can be used (e.g., } \\
\text { glass, silicone, metal, Teflon, } \\
\text { microfabricated soft and elastic "stencils" } \\
\text { or agarose gels), cells are visualized } \\
\text { several manner (e.g., photomicrography } \\
\text { or labeled with fluorescence and } \\
\text { measured with a microplate reader), } \\
\text { migratory capacity and interaction } \\
\text { between two different populations can } \\
\text { be compared, kinetic measurement, this } \\
\text { is currently the only method that allows } \\
\text { investigation of the effects of ECM } \\
\text { proteins on cell motility, allows high } \\
\text {-throughput screening (HTS) }\end{array}$ & $\begin{array}{l}\text { only adherent cells can be used, only } \\
\text { horizontal movement can be detected }\end{array}$ & $\begin{array}{l}\text { Menyhárt et al., } 2016 \text { [64], } \\
\text { Poujade et al., } 2007 \text { [173], } \\
\text { Gough et al., } 2011 \text { [175], } \\
\text { Pratt et al., 1984 [176] } \\
\text { Varani et al., 1978 [177] } \\
\text { Kroening 2010 [178] }\end{array}$ \\
\hline $\begin{array}{l}\text { Microcarrier bead and spheroid } \\
\text { migration assays }\end{array}$ & migration & $\begin{array}{l}\text { adherent cells and spheroids can be used, } \\
\text { vertical and horizontal movement, } \\
\text { plastic surface and beads can be used, } \\
\text { microscope, time-lapse microscope and } \\
\text { fluorescent staining can be used to count } \\
\text { the cells, endpoint and kinetic } \\
\text { measurement can be performed }\end{array}$ & & $\begin{array}{l}\text { Menyhárt et al., } 2016 \text { [64], } \\
\text { Rosen et al., } 1990 \text { [179], } \\
\text { Konduri et al., } 2001 \text { [180] }\end{array}$ \\
\hline
\end{tabular}


Table 8. Cont.

Migration $\mathrm{A}$

Principal

migration and morphology

\section{Advantage}

adherent and suspension cells can be used, migratory behavior and

morphological responses can be

visualized in real time by time-lapse microscopy, endpoint and kinetic

measurement can be performed, suitable for rare cell types and expensive compounds due to its small cell and volume require, liquid handling and image processing can be fully automated, allows high- throughput

$$
\text { imaging system (HTIS) }
$$

adherent and suspension cells can be used, time-lapse video microscopy, 3D tracking is also possible, analysis of nvasive properties of single cells as we as of populations can be performed kinetic measurement

D force microscope and coated magnetic beads can be also used ma tracker can be applied
Disadvantage

References only horizontal movement can be detected
Menyhárt et al., 2016 [64],

Chaubey et al., 2011 [181]

Echeverria et al., 2010 [182]
Mechanical properties

migration and invasion in 3D structure only horizontal movement can be

detected, requires specialized

microscopes and image analyzing software

only adherent cells can be tested, only horizontal movement can be detected endpoint assay
Menyhárt et al., 2016 [64] Miura 2005 [183], Gu et al., 2007 [184], Niinaka et al., 2001 [186

\begin{tabular}{c}
$\begin{array}{c}\text { high-speed video camera, video sp } \\
\text { tracker can be applied }\end{array}$ \\
\hline
\end{tabular}




\subsubsection{Label-Free Biosensors}

The concept of labeling is rooted in the poor sensitivity of many traditional biological molecular detection techniques. Biomolecules are mostly composed of light elements with small masses and optical polarizabilities and are only rarely fluorescent. The techniques based on electrons, $\mathrm{X}$-rays, visible light and mass spectrometry, which have been so successful in physics and chemistry, become much less potent when moved to the world of biology. By artificially coupling a biomolecule to an artificial entity with an electron density, optical polarizability or mass that may be orders of magnitude greater than that of the biomolecule, the latter suddenly becomes "visible" to the technique being employed to detect it. The euphoria that followed this sudden visibility tended to completely overwhelm continuing appraisal of whether the labeling itself might mask the biological effect that was the primary object of investigation [189].

The advent of new technologies sufficiently sensitive to remove the need to label the biomolecules to make them visible opened up a new world of label-free detection [190-192]. Natural compounds usually have small molecular weight where labeling can be problematic or even impossible, especially if their binding pocket is small or embedded. Label-free biosensors are emerging tools to investigate the mode of action of small molecules as well. They eliminate all of the disadvantages of the classical techniques listed above, because these methods do not require labels or dyes, which may disturb the samples. Furthermore, in general, the measurement procedures are not difficult, relatively cheap, and not timeconsuming. In the field of natural compound research (for example active compounds in traditional Chinese medicines), novel methods, for example, resonant waveguide grating (RWG) $[50,193,194]$ and holographic microscopy can be applied without using any dyes or other labels [195].

These techniques, particularly the highly sensitive waveguide-based methods [57,194,196-202], constitute highly promising novel phenotypic assays for drug discovery [203] owing to their capacity to reveal the complexity of drug actions and interactions and provide a holistic view of receptor-ligand interactions in living cells. Waveguide sensors are based on the phenomenon of the evanescent field generated by waveguided (usually visible) light being modulated by the presence of drugs, proteins and other biomolecules and living cells [204,205]. An adlayer, which may be constituted from a phospholipid membrane, extracellular matrix proteins or tissue is firstly placed onto the planar waveguide, where it is in contact with physiological medium containing the analyte of interest, such as the natural compound [204,205]. Molecular processes taking place in or on this adlayer modify the parameters of light propagating in the waveguide, any of which can serve as signal transducers $[205,206]$.

Label-free techniques are especially useful for kinetic monitoring of biological events [207-209], even at single-cell level [210]. So they have become more and more popular in the field of drug discovery and in other areas focusing on the biological roles of small molecules $[1,203]$. Furthermore, the same techniques can be readily adapted to measure the dynamics of cell shape changes [211]. Cell adhesion assays and cell migration tests can be achieved in a completely label-free way, with in situ exposure to the natural compounds and, indeed, any drug. For example, a recent study of Peter et al. applied holographic microscopy to quantitatively show that EGCG reduced the motility speed and migration of HeLa cells [195]. Holographic microscopy creates 3D images of cells and the changes in cell morphology due to EGCG could be observed in real time [195].

These techniques are more and more important to systematically study the effects of active substances on cell behavior, especially cell adhesion, and to investigate different biological materials (such as membranes and matrices) and living cells in a high-throughput format [50]. In a recent experiment, Peter et al. showed that EGCG can block the RGD (Arg-Gly-Asp) motif, an important cell adhesion ligand and directly affect matrix properties by hydrogen bonding (Figure 7) [50]. The other novelty of this study is that the polymer 
coating fabrication, its treatment with the small EGCG molecule (a green tea polyphenol), and the observation of cell adhesion could be all studied online using a high-throughput RWG biosensor, with different EGCG and oxidized EGCG concentrations [50].

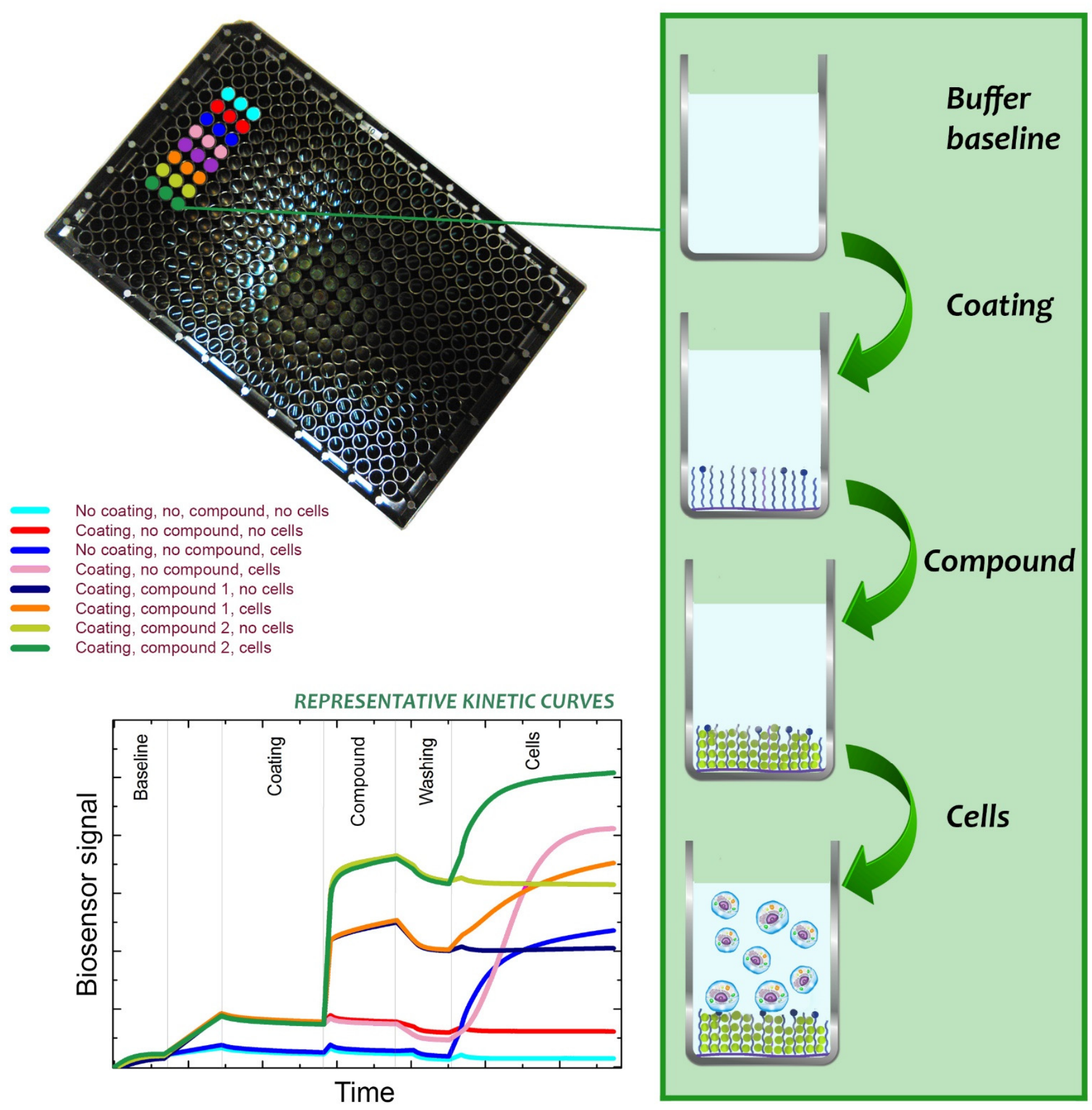

Figure 7. Multicomponent study measuring cancer cell adhesion on a natural compound-treated coating [50]. A 384-well biosensor plate was used in the experiment (left) comprising the manipulation steps in a typical well (right). Representative kinetic curves are also shown (bottom).

This and similar methodologies should be applicable to other extracellular matrix interactions with small natural compounds (Figure 7).

Recently, it was concluded that the shape of the kinetic curves obtainable with the label-free biosensor can be used to quantify in vitro cell viability in a fast and highly sensitive manner [59]. 
Natural compounds are generally small molecules that can self-associate into colloidal aggregates in aqueous buffer [212]. In the early stage of drug discovery, this phenomena is the principal cause of false results [212]. Wang et al. reported RWG-based assays to identify natural compound aggregation and characterize its influence on membrane receptors in living cells [212]. They showed that the colloidal aggregates may cause false activity in DMR desensitization assays [212]. A series of RWG-based assays for colloidal aggregate detection and characterization of their promiscuity were developed [212]. RWG-based assays can be applied as practical tools to distinguish between real and false responses, providing useful reliable results in the early stages of drug discovery [212].

\subsubsection{Living Cell Movements-Holographic Microscopy}

The realization of in situ monitoring of living cell movements (i.e., crawling along the endothelium) is a very important advance [195,213]. There are anyway few techniques to study cell movements; classical ones are mostly directed at migration studies and they also have their drawbacks [195]. For instance, filter assays (Zigmond and Dunn chambers, Boyden chamber) measure cell migration over a membrane in response to chemoattractant compounds [195]. These assays are very specialized, requiring cells to migrate through both a matrix and the pores of a filter [213]; however, very few cell lines can migrate through both of them [195]. Single cell movements can be investigated by using time-lapse imaging, usually requiring fluorescent labels $[195,213]$. As discussed above, fluorescent imaging may disturb the cells and the imaging time is limited by bleaching of the fluorescent marker $[195,213]$. In contrast to fluorescent imaging, holographic microscopy is a label-free technique [195,214]. It is usually critical to observe and quantitatively record live cell behavior, especially directional movement (migration) and random movement (motility), and also the shape changes to understand the behavior of the cells in such environments and to be able to make inferences regarding further therapeutic possibilities [195]. Although traditional herbal extracts have become more and more popular for treating illnesses, the literature of systematic quantitative studies is still limited [1].

\section{Preparation of Natural Compounds}

Natural products with their broad chemical diversity and bioactivity spectrum are sought after by the pharmaceutical industry and they continue to provide new structures with promising effects and to offer templates for the development of scaffolds of novel drug candidates. However, natural product discovery programs have been abandoned over the past 30 years by many pharmaceutical companies [215-217].

Natural products present their own challenges for drug discovery, including screening, isolation, characterization and optimization, which doubtless contributed to the decline in their pursuit by the pharmaceutical industry. In recent years, several technological and scientific developments-such as improved analytical tools, genome mining, engineering strategies, and microbial culturing - are addressing these challenges, preparing the way for new opportunities and interest in natural compounds [218,219].

Here, we briefly summarize recent technological developments that are facilitating natural product-based drug discovery, highlight selected applications and discuss key opportunities. Innovative compound identification from natural products requires a multidisciplinary approach utilizing numerous technologies [220].

Isolation and purification of natural compounds are the most important and difficult steps for molecular structure identification, in vitro testing, quantity control and further industrial production. The natural compounds are usually in complex matrix material and the active moieties are present in low concentration [220] which are often accompanied by co-occurring irrelevant common metabolites accumulated in high amounts. Selection of appropriate techniques and strategies is essential for getting the target compounds at high yield. Over the past decades, many types of new extraction, isolation and purification techniques (classical solvent extraction procedures, ultrasound-assisted extraction (UAE), microwave-assisted extraction (MAE), 
extraction with ionic liquids, accelerated (pressurized) solvent extraction (ASE), supercritical fluid extraction (SFE), extraction on solid phases, distillation methods, membrane filtration, preparative high-performance liquid chromatography (HPLC), counter-current chromatography (CCC), supercritical fluid chromatography (SFC), etc.) have been applied. With developments in separation science and microplatebased in vitro high-throughput screening (HTS) assays, natural compound research gained remarkable momentum recently. Nevertheless, despite these developments of extraction, separation, analytical and structural elucidation techniques, isolation of natural compounds from plants, marine organisms or microorganisms is challenging, with problems including post-harvest changes in material quality [221,222]. Extraction is the first step to separate most natural products from the raw materials. The method progresses through the following stages: (i) solvent penetration into the matrix; (ii) the components dissolve in the solvent; (iii) the components diffuse out of the matrix. A brief but excellent summary of the various extraction methods used for natural products is presented by Zhang and co-workers [223]. A more detailed description is presented in a book chapter by Cavalcanti et al. [224]. The analyses of extracts, fractions, isolates, compounds from different natural matrices, studies on chemotaxonomy, chemical fingerprinting, metabolome elucidation, and structural evaluation have become easier because of the availability of a number of instrumental analytical techniques, e.g., GC-MS, LC-PDA, LC-MS, LC-FTIR, LC-NMR, LC-NMR-MS, and CE-MS, NMR, NIR, FT-IR.

Atanasov and co-workers [219] have detailed the traditional bioactivity-guided isolation process and its limitations, and also ideas on addressing them. The general process begins with the extraction steps and the method applied determines which type of compounds will be present in the particular extract (solvents with hydrophilic chemical character will result in a higher abundance of hydrophilic compounds). Following the identification of an extract with promising bioactivity, the next step is its (often multiple) consecutive bioactivity-guided fractionation until the individual active compound or compounds are isolated. To isolate such new antiproliferative/antimicrobial compounds from a series of extracts, highthroughput label-free activity screening by label-free biosensors could be applied. The identities of the pure compounds responsible for an extract's activity can be determined by bioactivity-guided fractionation using novel label-free biosensor systems [1,204-214].

A systems biology-guided approach coupled with application of commensurate technologies (genomics, proteomics, metabolomics, in silico modeling, etc.) should provide new opportunities for identifying new and better drug candidates. Molecular libraries of lead compounds from natural products will serve as sources of lead extracts/compounds for innovative drugs (Figure 8). 


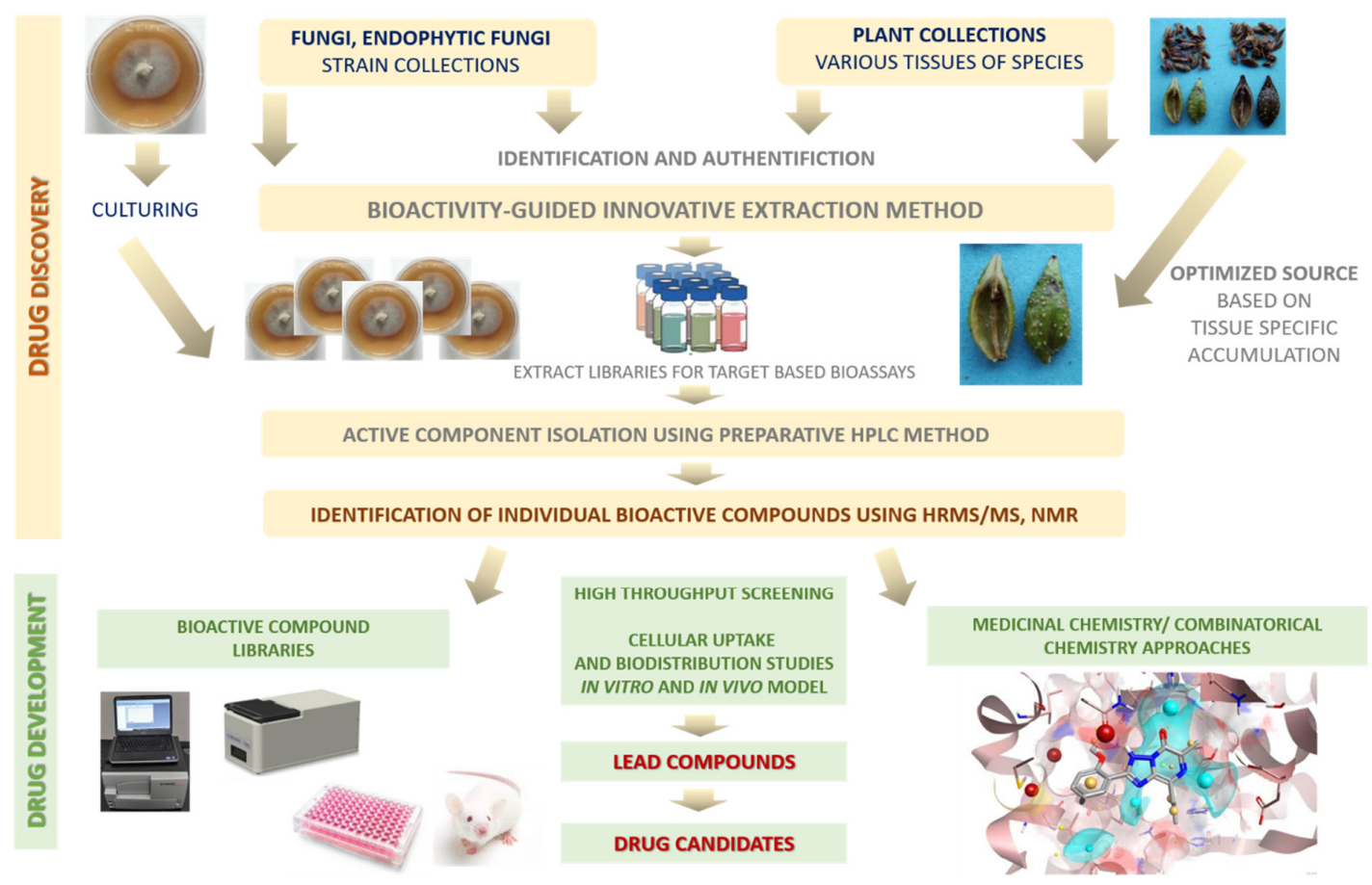

Figure 8. Bioactivity-guided isolation of natural compounds.

\section{Natural Compounds of Plant, Animal and Fungal Origin}

We summarize and categorize those natural compounds found in the literature that affect cellular adhesion and migration. The sources of the active compounds are divided into three groups; plants (Table 9), animals (Table 10), or fungi (Table 11). The compounds produced by these organisms include primary and secondary metabolites. They show structural and functional diversities, which are the result of biosynthetic processes modulated by natural selection. Defense molecules—antimicrobial peptides (AMPs) - are commonly produced to resist stresses. These oligo- and polypeptides are synthesized by ribosomes or via non-ribosomal peptide synthetases. Many AMPs exhibit broad-spectrum antimicrobial and anticancer activity. Plants are a remarkably promising source of these molecules and they are also considered to affect plant growth and development [225]. AMPs can be classified into cationic or anionic compounds according to their net charge. Their function, isolation and other aspects have been reviewed [225-228]. 
Table 9. Effects of plant-derived natural compounds on cell adhesion and movement. The table summarizes the applied methods and techniques as well.

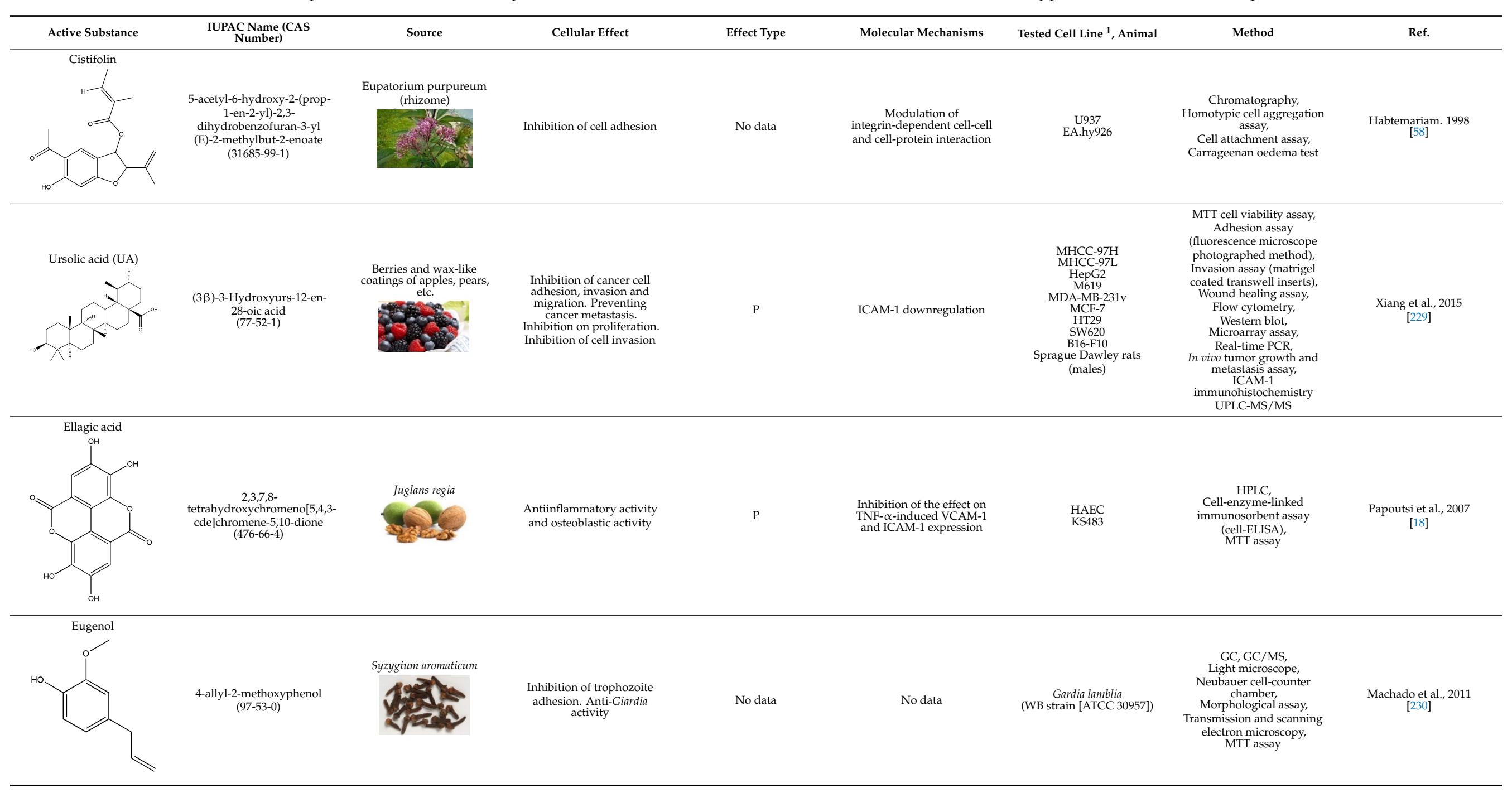


Table 9. Cont.

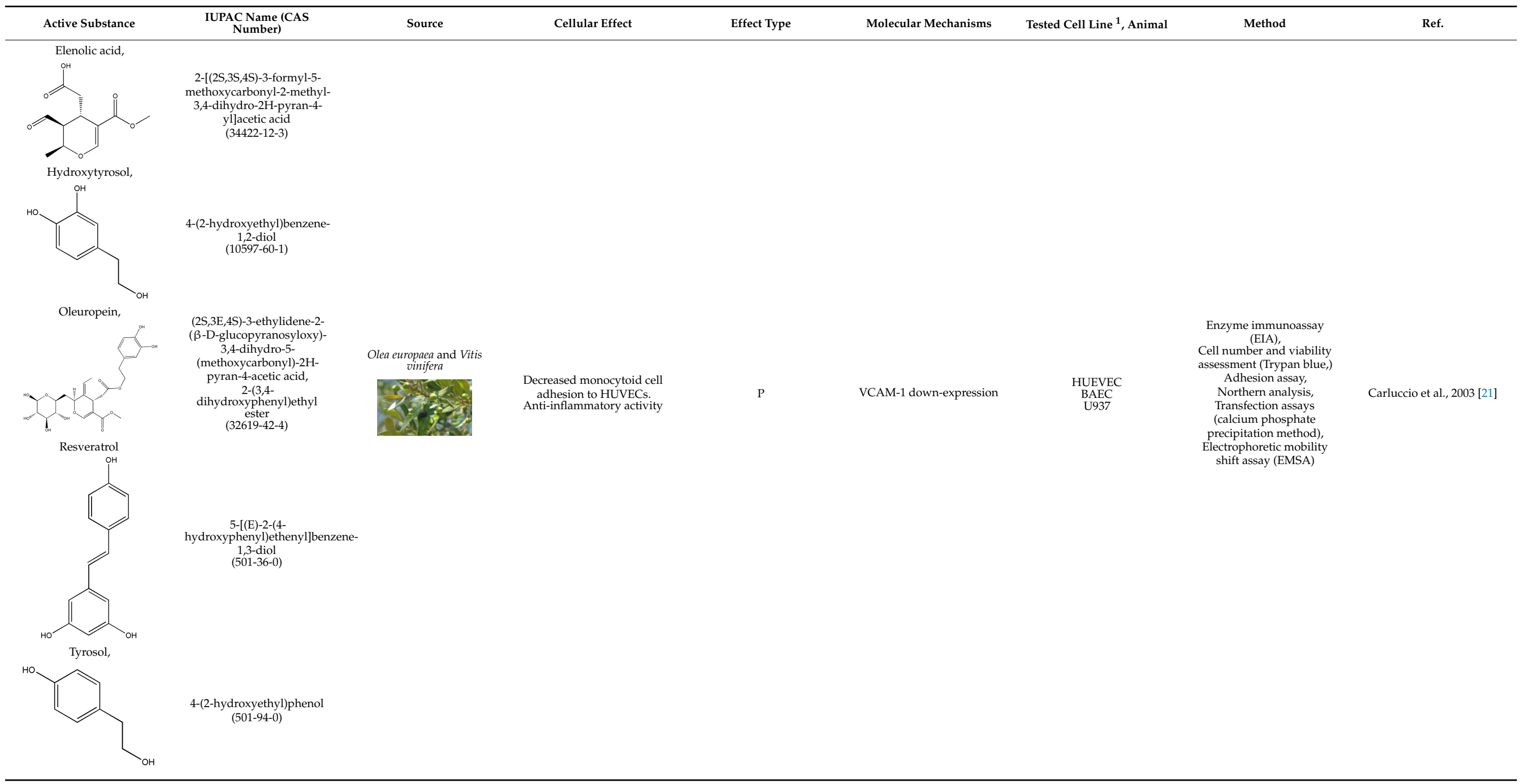


Table 9. Cont.

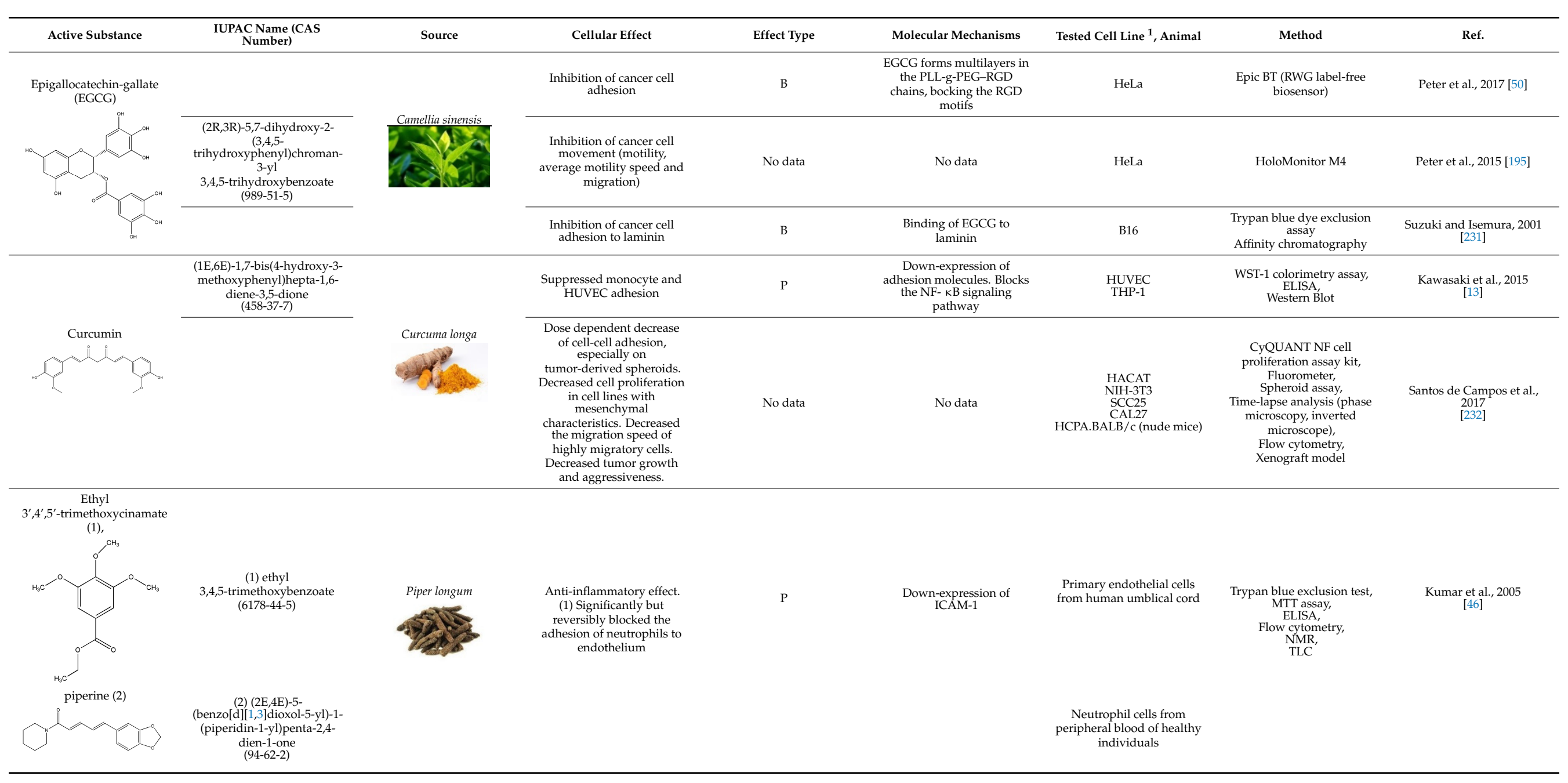


Table 9. Cont.

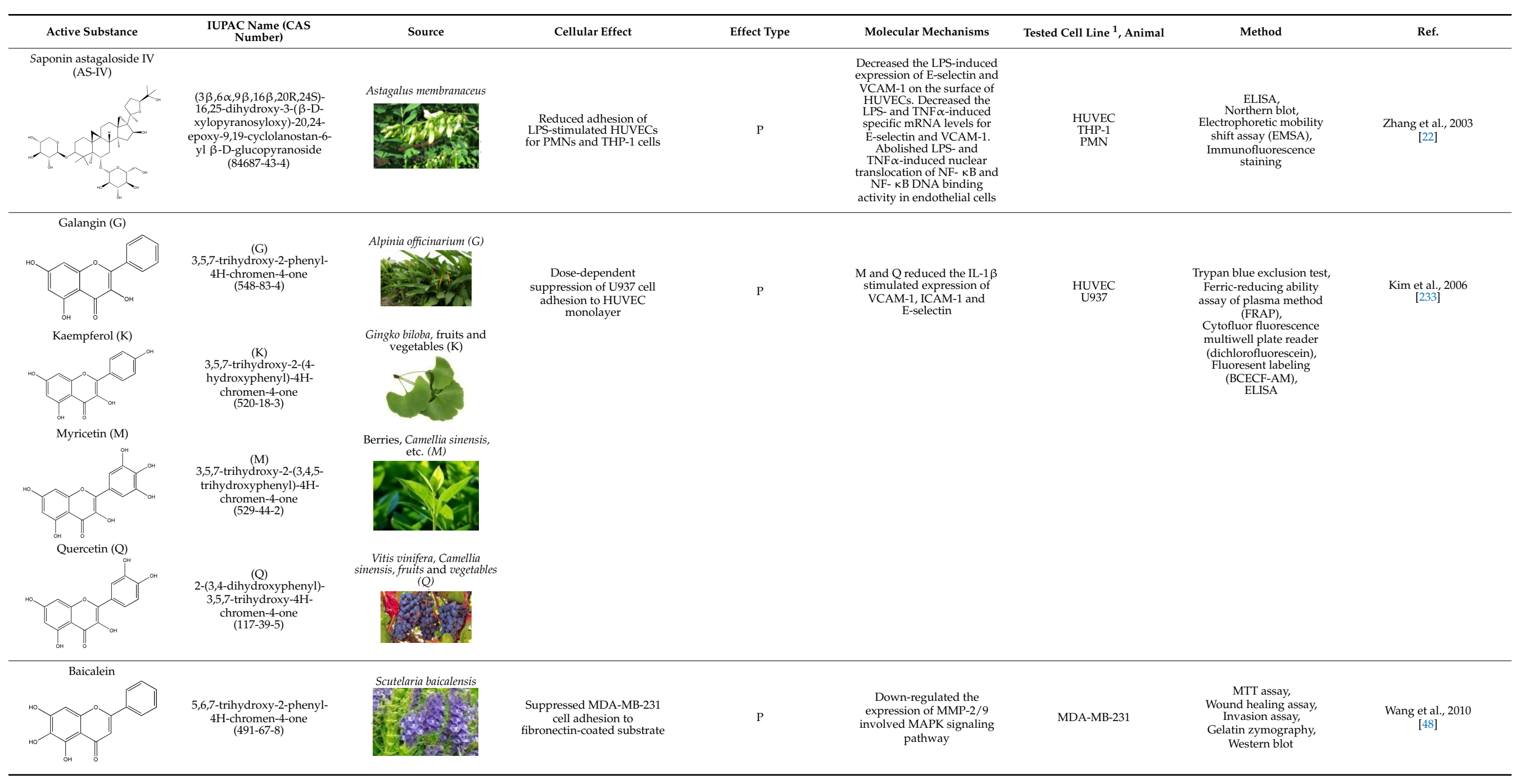


Table 9. Cont

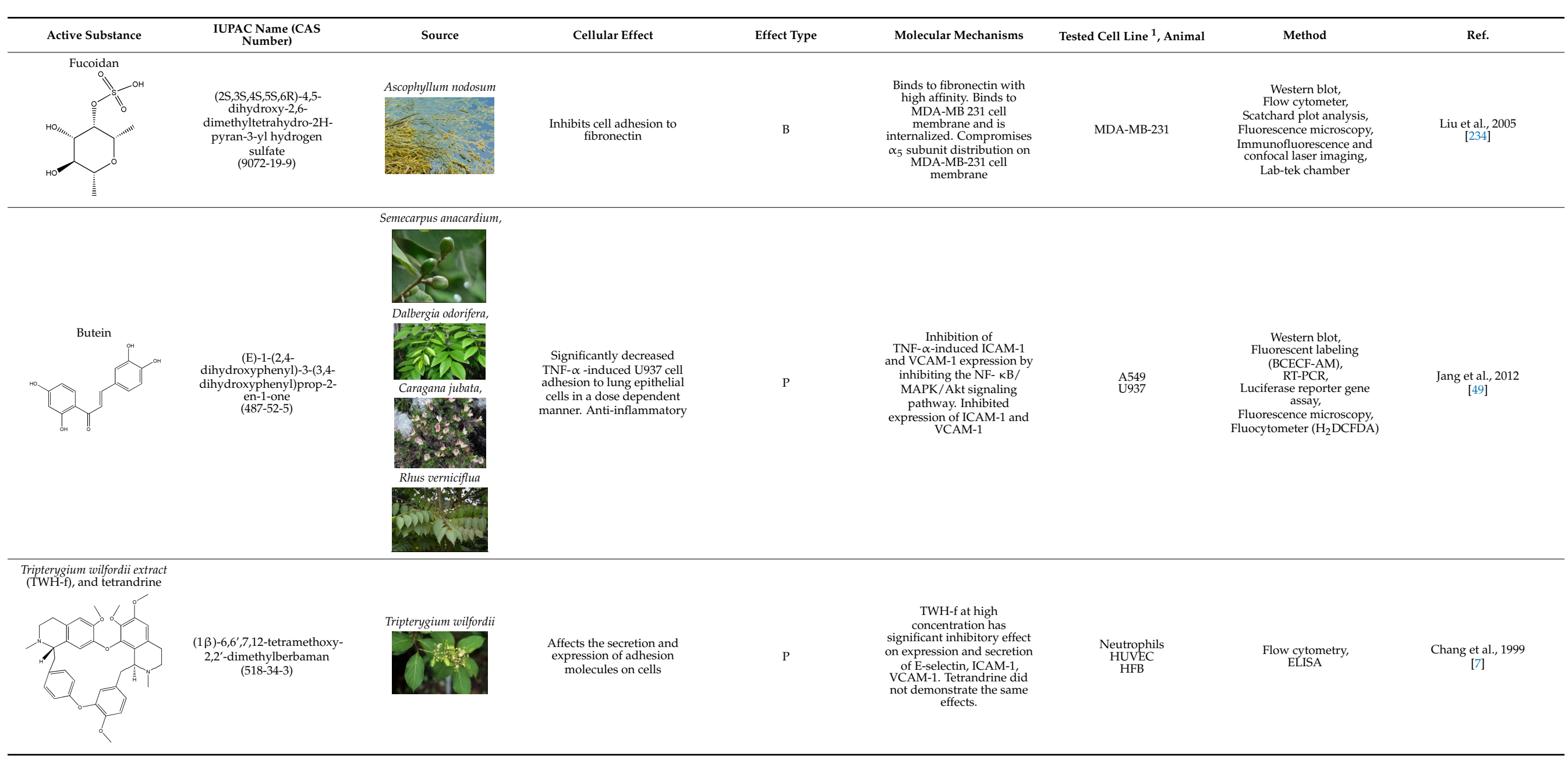


Table 9. Cont.

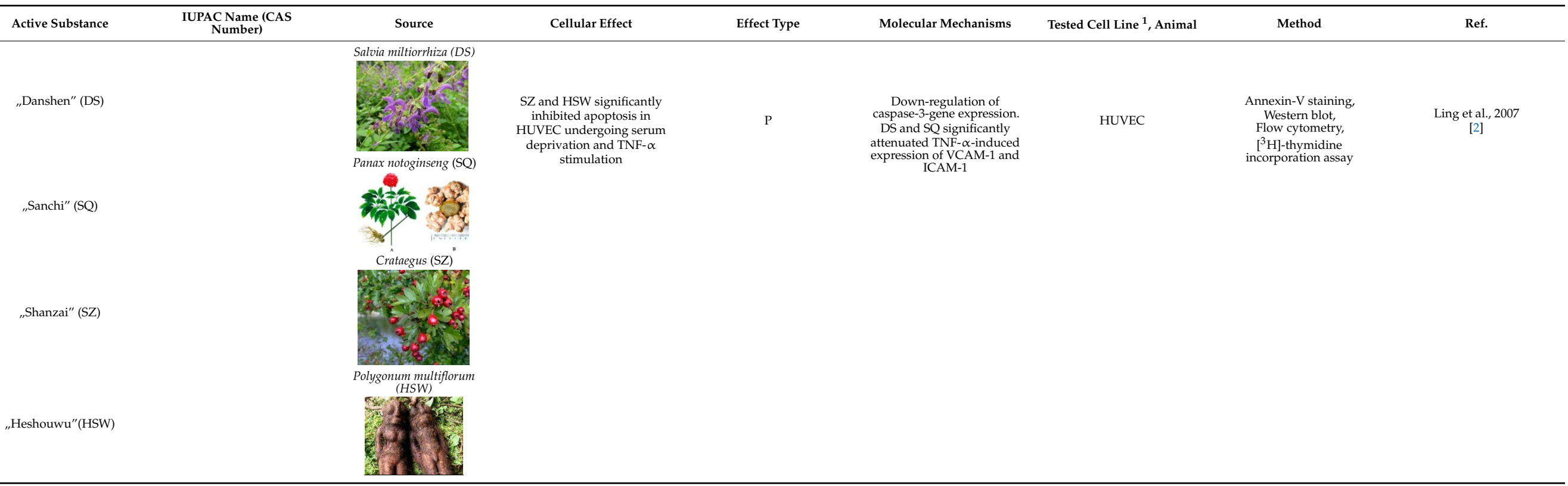

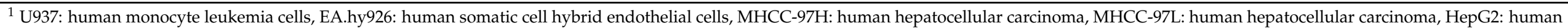

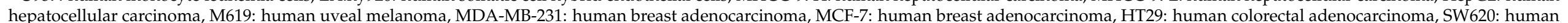

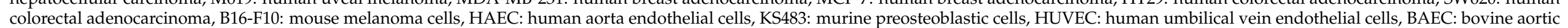

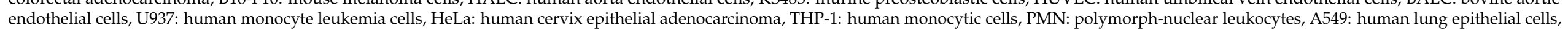

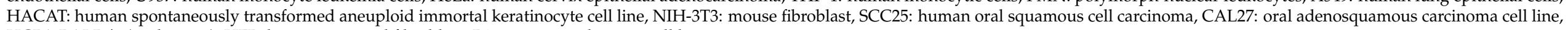
HCPA.BALB/c (nude mice), HFB: human synovial fibroblast, B16: mouse melanoma cell line. 
Table 10. Effects of animal-derived natural compounds on cell adhesion and movement. The table summarizes the applied methods and techniques as well.

\begin{tabular}{|c|c|c|c|c|c|c|c|}
\hline Active Substance & Source & Cellular Effect & Effect Type & $\begin{array}{l}\text { Molecular } \\
\text { Mechanisms }\end{array}$ & $\begin{array}{l}\text { Tested Cell Line }{ }^{1}, \\
\text { Animal }\end{array}$ & Method & Ref. \\
\hline Disintegrin & $\begin{array}{c}\begin{array}{c}\text { Calloselasma rhodostoma } \\
\text { (venom) }\end{array} \\
\text { ? }\end{array}$ & $\begin{array}{l}\text { Cell detachment. } \\
\text { Actin cytoskeleton } \\
\text { perturbed }\end{array}$ & $\mathrm{B}, \mathrm{P}$ & $\begin{array}{l}\text { Prevention of integrin } \\
\alpha_{V} \beta_{3} \text { interaction. } \\
\text { Decreased pp } 125^{F A K} \\
\text { phosphorylation }\end{array}$ & HUVEC & $\begin{array}{c}\text { Cell detachment assay } \\
\text { (Trypan blue), } \\
\text { MTT assay, } \\
\text { Flow cytometry, } \\
\text { DNA fragmentation } \\
\text { assay, } \\
\text { Precipitation of cell } \\
\text { extracts and } \\
\text { immunoprecipitation, } \\
\text { Western blot, } \\
\text { Immunofluorescence } \\
\text { microscopy }\end{array}$ & Wu et al., 2002 [55] \\
\hline Echistatin & $\begin{array}{l}\text { Echis carinatus } \\
\text { (venom) }\end{array}$ & Decreased cell adhesion & B & $\begin{array}{l}\text { Prevention of } \alpha_{\mathrm{IIb}} \beta_{3}, \\
\alpha_{\mathrm{v}} \beta_{3} \text { and } \alpha_{5} \beta_{1} \text { integrin } \\
\text { interactions }\end{array}$ & HeLa & $\begin{array}{c}\text { Epic BT (RWG label-free } \\
\text { biosensor) }\end{array}$ & Szekacs et al., 2018 [51] \\
\hline
\end{tabular}


In the cases of plant or fungal origin, it has been well known for centuries that active substances can be extracted from individual plant organs (i.e., leaves, flowers, rhizomes, fruits, seeds, roots, stems, bark and xylem). These parts can be consumed as hot water infusions (e.g., green tea, herbal infusions), as spices (e.g., pepper, clove), as raw fruits or extruded/fermented products (e.g., red wine, olive oil). Such natural compounds are consumed day-by-day as food, but their ability to cure diverse diseases has been known for thousands of years (e.g., in Chinese traditional medicine).

In our tables, if the literature information is too scanty to allow us to be more specific, we simply write $\mathrm{P}$ (pathway intervention involving gene expression) or $\mathrm{B}$ (cell adhesion inhibition by blocking specific receptor sites) to indicate the mechanism.

In case of animal origin, the most popular category of substance is serpent venom (Table 10). However, a recent study of Mattia et al. showed that edible insects and invertebrates can be a source of useful polyphenols as well [235]. For example, black ants (Lasius niger), mealworms (Tenebrio molitor) and grasshoppers contain the highest levels of total polyphenols [235]. More experiments are needed to understand whether eating insects and other invertebrates might be beneficial to humans [235], although we note that some cultures have, for example, regarded locusts as comestible for millennia.

Statins, cholesterin-lowering active ingredients, are among the most widely prescribed medicines. Naturally occurring statins (e.g., lovastatin and mevastatin) are produced by different fungi, a synthetic derivate (simvastatin) of a fungal fermentation product is found in pharmacopeias alongside synthetic statins (e.g., atorvastatin, fluvastatin). In Table 11, the synthetic derivatives are labeled (syn). Lovastatin is naturally produced by e.g., Pleurotus ostreatus (oyster mushroom) [236] and mevastatin was first isolated from the Penicillium citrinum [237]. Several pleiotropic effects of statins have been revealed, including enigmatic effects on cancer [238-240]. Naturally occurring statins can suppress cell migration, invasion, and cell adhesion (Table 8). The effects of such suppression on cancer metastasis would appear to be obvious. We focus on studies in which cell migration, invasion and adhesion have been studied in vitro. Another metabolite type, the macrosphelides (MSs; A, B, C, D, E, F, G, H, etc.), are macrolides produced by several fungal strains, for example Microsphaeropsis sp. [241]. These compounds and metabolites from the peribysin group are also detailed in Table 11. 
Table 11. Effects of fungi-derived natural compounds on cell adhesion and movement. The table summarizes the applied methods and techniques as well.

\begin{tabular}{|c|c|c|c|c|c|c|c|c|}
\hline Active Substance & $\begin{array}{l}\text { IUPACName (CAS } \\
\text { Number) }\end{array}$ & Source & Cellular Effect & Effect Type & Molecular Mechanisms & Tested Cell Line ${ }^{1}$, Animal & Method & Ref. \\
\hline $\begin{array}{l}\text { Ganoderma lucidum } \\
\text { polysaccharide }\end{array}$ & & Ganoderma lucidum & $\begin{array}{l}\text { Inhibition of tumour cell } \\
\text { adhesion }\end{array}$ & $\mathrm{P}$ & $\begin{array}{l}\text { Ateration in } \beta 1 \text {-integrin } \\
\text { expression }\end{array}$ & MT-1 & $\begin{array}{l}\text { Coomassie blue staining, } \\
\text { Western blot }\end{array}$ & Wu et al., 2006 [47] \\
\hline $\begin{array}{c}\text { Rhodostomin } \\
\text { peptide }\end{array}$ & & Pichia pastoris & $\begin{array}{c}\text { Inhibition of cell adhesion, } \\
\text { platelet aggregation and } \\
\text { the binding of fibrinogen to } \\
\text { platelet by ARGDWN } \\
\text { mutants }\end{array}$ & B & $\begin{array}{l}\text { Prevention of integrin } \\
\alpha I \mathrm{Ilb} \beta 3 \text { interaction }\end{array}$ & $\begin{array}{l}\mathrm{CHO} \\
\mathrm{K} 562\end{array}$ & $\begin{array}{l}\text { Mass spectrometry, } \\
\text { Fibrinogen binding assay, } \\
\text { Flow cytometry, } \\
\text { Platelet aggregation assay, } \\
\text { Nuclear magnetic } \\
\text { resonance spectroscopy, } \\
\text { Molecular docking }\end{array}$ & Chang et al., 2017 [56] \\
\hline Cyclopeptolide HUN & $\begin{array}{c}3- \\
\text { ((2R,5S,8S, } 11 \mathrm{~S}, 14 \mathrm{~S}, 17 \mathrm{R}, 20 \mathrm{~S})- \\
\text { 8,11-diisobutyl-14-((1- } \\
\text { methoxy-1H-indol-3- } \\
\text { yl)methyl)-7,13,19,20- } \\
\text { tetramethyl-18-methylene- } \\
\text { 5-((R)-2-methylheptyl)-17- } \\
\text { ((R)-2-methylhexyl)- } \\
\text { 3,6,9,12,15,21-hexaoxo-1- } \\
\text { oxa-4,7,10,13,16,19- } \\
\text { hexazacyclohenicosan-2- } \\
\text { yl)propanenitrile } \\
\text { (129893-84-1) }\end{array}$ & Bartalinia robillardoides & $\begin{array}{l}\text { Inhibition of VCAM-1 and } \\
\text { ICAM-1 }\end{array}$ & $\mathrm{P}$ & $\begin{array}{l}\text { Inhibition of the expression } \\
\text { of VCAM- } 1 \text { and ICAM- } 1\end{array}$ & HMEC-1 & ELISA & Schreiner et al., 2004 [242] \\
\hline asin-E & 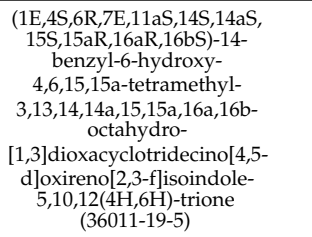 & $\begin{array}{l}\text { Mycotypha sp. UMF-006 } \\
\text { (soil) }\end{array}$ & $\begin{array}{l}\text { Inhibition of cell } \\
\text { aggregation and adhesion }\end{array}$ & No data & No data & $\begin{array}{l}\text { HL-60 } \\
\text { CHO }\end{array}$ & $\begin{array}{l}\text { Cell aggregation assay, } \\
\text { Adhesion assay } \\
\text { (CFSE-labelling }\end{array}$ & $\begin{array}{l}\text { Takamatsu et al.n } 2002 \\
{[243]}\end{array}$ \\
\hline Cordy & $\begin{array}{l}\text { (2R,5S)-2-(6-amino-9H- } \\
\text { purin-9-yl)-5- } \\
\text { (hydroxymethyl) } \\
\text { tetrahydrofuran-3-ol } \\
(73-03-0)\end{array}$ & Cordiceps militaris & $\begin{array}{l}\text { Inhibition of motility, } \\
\text { invasion and migration }\end{array}$ & $\mathrm{P}$ & $\begin{array}{l}\text { Inhibition of PI3K/Akt } \\
\text { pathway and expression of } \\
\text { claudin family proteins. } \\
\text { Downregulation of MMP } \\
\text { activity }\end{array}$ & LNCaP & $\begin{array}{l}\text { Wound healing migration } \\
\text { assay, } \\
\text { MTT assay, } \\
\text { Boyden chamber, } \\
\text { Matrigel invasion assay, } \\
\text { Measurement of TER } \\
\text { (EVOM voltohmmeter) }\end{array}$ & Jeong et al., 2012 [244] \\
\hline Fusarisetin & 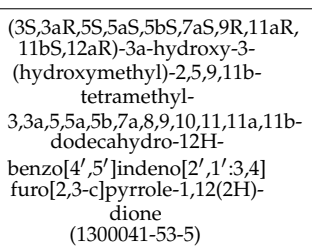 & Fusarium sp. FN080326 & Inhibition of migration & $\mathrm{P}$ & Pathway inhibition & MDA-MB-231 & $\begin{array}{l}\text { Scratch wound assay, } \\
\text { Boyden chamber transwell } \\
\text { assay }\end{array}$ & Xu et al., 2012 [245] \\
\hline
\end{tabular}


Table 11. Cont.

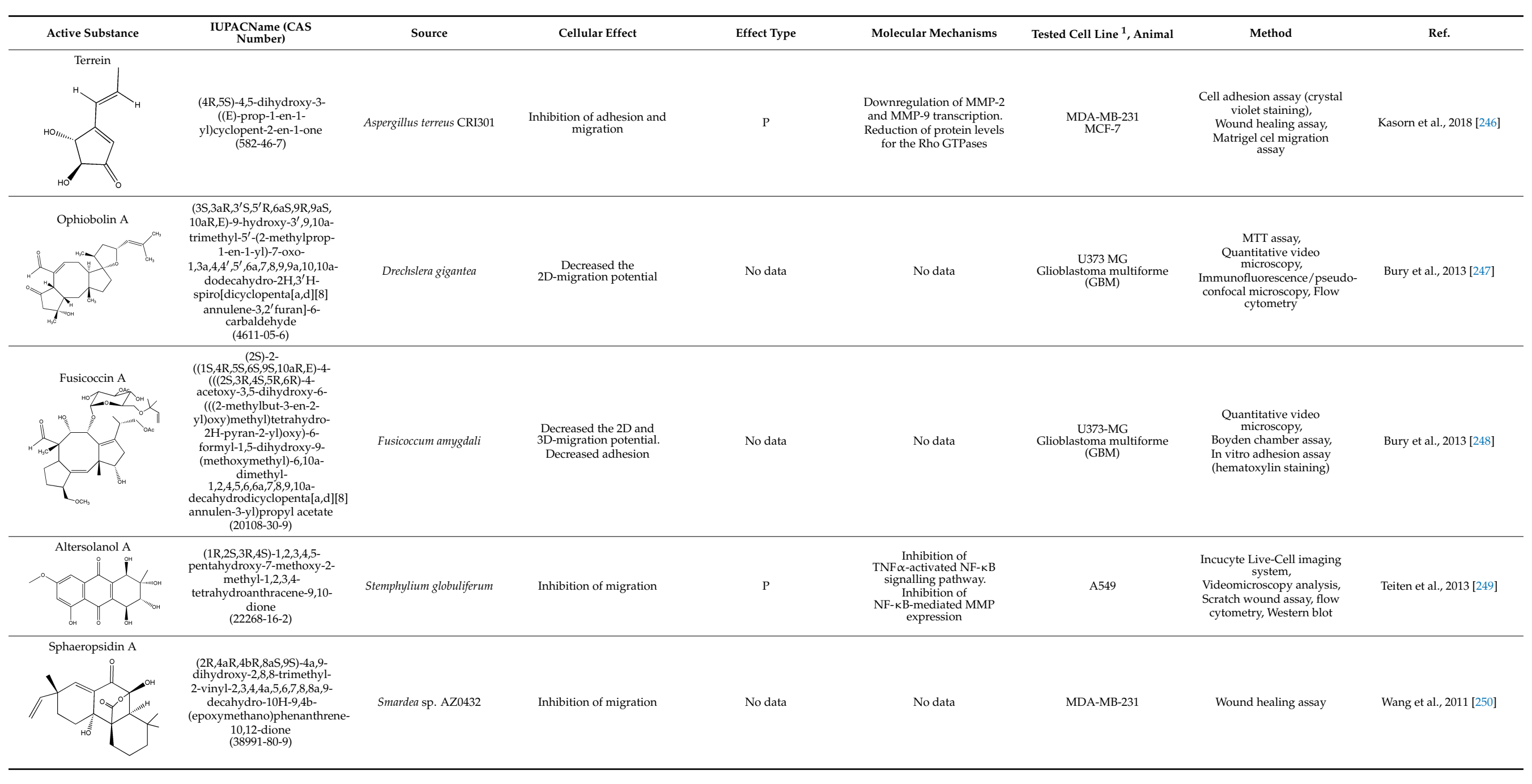


Table 11. Cont.

\begin{tabular}{|c|c|c|c|c|c|c|c|c|}
\hline Active Substance & $\begin{array}{c}\text { IUPACName (CAS } \\
\text { Number) }\end{array}$ & Source & Cellular Effect & Effect Type & Molecular Mechanisms & Tested Cell Line ${ }^{1}$, Animal & Method & Ref. \\
\hline & $\begin{array}{c}\text { (3R,5aS,6S,10aR)-6- } \\
\text { hydroxy-3-- } \\
\text { (hydroxymethyl)-2-methyl- } \\
\text { 2,3,5a,6-tetrahydro-10H- } \\
\text { 3,10a- } \\
\text { epidithiopyrazino[1,2- } \\
\text { a]indole-1,4-dione } \\
(67-99-2)\end{array}$ & $\begin{array}{l}\text { Unidentified fungal strains } \\
\text { Y90086/Y80805 }\end{array}$ & Inhibition of migration & No data & No data & HUVEC & Wound migration assay & Lee et al., 2001 [251] \\
\hline & $\begin{array}{c}\text { (3R,5aS,6S,10aR)-6- } \\
\text { hydroxy-3- } \\
\text { (hydroxymethyl)-2-methyl- } \\
\text { 3,10a-bis(methylthio)- } \\
2,3,5 \mathrm{a}, 6,10,10 \mathrm{1} \text { - } \\
\text { hexahydropyrazino[1,2- } \\
\text { alindole-1,4-4ione } \\
\text { (74149-38-5) }\end{array}$ & & & & & & & \\
\hline & $\begin{array}{c}\text { (3S,3aR,4S,6S,6aR,7E,10S, } \\
\text { 12R,13E,15R,15aS)-3-benzyl- } \\
\text { 6,12-dihydroxy-4,10,12- } \\
\text { trimethyl-5-methylene-1,11- } \\
\text { dioxo- } \\
\text { 2,3,3a,4,5,6,6,a,9,10,11,12,15- } \\
\text { dodecahydro-1H- } \\
\text { cycloundeca[dlisoindol-15- } \\
\text { yl acetate } \\
\text { (22144-77-0) }\end{array}$ & $\begin{array}{l}\text { Not mentioned (but many } \\
\text { fungi produce, e.g., } \\
\text { Zygosporium mansonii) }\end{array}$ & $\begin{array}{l}\text { Inhibition of actin } \\
\text { polymerization, decreased } \\
\text { cell motility and } \\
\text { colonization. Inhibition of } \\
\text { actin polymerization }\end{array}$ & No data & No data & $\begin{array}{l}\text { MFC-7 } \\
\text { A549 }\end{array}$ & $\begin{array}{c}\text { Quantitative } \\
\text { videomicroscopy, } \\
\text { Scratch wound assay }\end{array}$ & Hayot et al., 2006 [252] \\
\hline & $\begin{array}{l}\text { 2-amino-2-(4- } \\
\text { octylphenethyl)propane- } \\
\text { 1,3-diol } \\
\text { (162359-55-9) }\end{array}$ & Isaria sinclairii & $\begin{array}{l}\text { Inhibition of cell migration, } \\
\text { motility and invasion }\end{array}$ & $\mathrm{P}$ & $\begin{array}{l}\text { Inhibition of RhoA-GTPase } \\
\text { expression }\end{array}$ & $\underset{\text { PC3 }}{\text { DU145 }}$ & $\begin{array}{l}\text { Wound closure assay, } \\
\text { 3D collagen colony forming } \\
\text { assay }\end{array}$ & Zhou et al., 2006 [253] \\
\hline
\end{tabular}


Table 11. Cont.

\begin{tabular}{|c|c|c|c|c|c|c|c|c|}
\hline Active Substance & $\begin{array}{l}\text { IUPACName (CAS } \\
\text { Number) }\end{array}$ & Source & Cellular Effect & Effect Type & Molecular Mechanisms & Tested Cell Line ${ }^{1}$, Animal & Method & Ref. \\
\hline \multicolumn{9}{|c|}{ Staitins } \\
\hline & $\begin{array}{c}\text { (1S,3R,7S,8S,8aR)-8-(2- } \\
\text { ((2S,4R)-4-hydroxy-6- } \\
\text { oxotetrahydro-2H-pyran-2- } \\
\text { yl)ethyl)-3,7-dimethyl- } \\
\text { 1,2,3,7,8,8-- } \\
\text { hexahydronaphthalen-1-yl } \\
\text { (S)-2-methylbutanoate } \\
\text { (75330-75-5) }\end{array}$ & \multirow{5}{*}{ Pleurotus ostreatus ** } & $\begin{array}{l}\text { Inhibition of EGF-induced } \\
\text { migration and invasiveness }\end{array}$ & $\mathrm{P}$ & $\begin{array}{l}\text { Inhibition of translocation } \\
\text { of RhoA }\end{array}$ & PANC-1 & Matrigel invasion assay & $\begin{array}{c}\text { Kusama et al., } 2001 \\
{[254]}\end{array}$ \\
\hline & $\begin{array}{c}\text { (3S,5R,E)-7-(3-(4- } \\
\text { fluorophenyl)-1-isopropyl- } \\
\text { 1H-indol-2-yl)-3,5- } \\
\text { dihydroxyhept-6-enoic acid } \\
\text { (93957-54-1) }\end{array}$ & & $\begin{array}{l}\text { Inhibition of tumor cell } \\
\text { attachement and migration }\end{array}$ & No data & No data & F3II & $\begin{array}{l}\text { Adhesion assay, } \\
\text { Migration assay (in vitro } \\
\text { wound assay) }\end{array}$ & Alonso et al., 1998 [255] \\
\hline syn)) & & & $\begin{array}{l}\text { Suppressed the } \\
\text { EGF-induced cell adhesion, } \\
\text { actin filament } \\
\text { reorganization and } \\
\text { transmigration } \\
\end{array}$ & $\mathrm{P}$ & $\begin{array}{l}\text { Suppression of Rho/ROCK } \\
\text { and FAK/paxillin signaling }\end{array}$ & ARO & $\begin{array}{l}\text { Matrigel invasion assay, } \\
\text { Cell adhesion assay }\end{array}$ & Zhong et al., 2005 [256] \\
\hline & & & $\begin{array}{l}\text { Inhibition of adhesion. } \\
\text { Reduced tumor cell } \\
\text { migration, attachement and } \\
\text { motility. Changed the } \\
\text { tumor cell shape }\end{array}$ & $P$ & $\begin{array}{c}\text { Reduced membrane } \\
\text { localization of Rho protein }\end{array}$ & F3II & $\begin{array}{l}\text { Adhesion assay, } \\
\text { Migration assay (in vitro } \\
\text { wound assay) }\end{array}$ & Farina et al., 2002 [257] \\
\hline & & & $\begin{array}{l}\text { Reduced migration and } \\
\text { invasion }\end{array}$ & $\mathrm{P}$ & $\begin{array}{l}\text { Diminished ERK signaling. } \\
\text { Impaired the regulation of } \\
\text { the mevalonate- and the } \\
\text { Ras-Raf-MEK-ERK } \\
\text { pathway. Affected the } \\
\text { post-translational } \\
\text { modification of H-Ras and } \\
\text { Rac1 }\end{array}$ & $\begin{array}{l}\text { U87 } \\
\text { U343 }\end{array}$ & $\begin{array}{c}\text { Migration assay, } \\
\text { Matrigel invasion assay }\end{array}$ & $\begin{array}{c}\text { Afshordel et al., } 2014 \\
{[\text { [258] }}\end{array}$ \\
\hline
\end{tabular}


Table 11. Cont.

\begin{tabular}{|c|c|c|c|c|c|c|c|c|}
\hline Active Substance & $\begin{array}{l}\text { IUPACName (CAS } \\
\text { Number) }\end{array}$ & Source & Cellular Effect & Effect Type & Molecular Mechanisms & Tested Cell Line ${ }^{1}$, Animal & Method & Ref. \\
\hline & $\begin{array}{l}\text { (1S,7S,8S,8aR)-8-(2-((2R,4R)- } \\
\text { 4-hydroxy-6-oxotetrahydro- } \\
\text { 2H-pyran-2-yl)ethyl)-7- } \\
\text { methyl-1,2,3,7,8,8a- } \\
\text { hexahydronaphthalen-1-yl } \\
\text { (S)-2-methylbutanoate } \\
\text { (73573-88-3) }\end{array}$ & Pleurotus ostreatus ** & $\begin{array}{l}\text { Inhibition of invasion and } \\
\text { migration }\end{array}$ & $\mathrm{P}$ & $\begin{array}{l}\text { Alteration in expression of } \\
\text { matrix-metalloproteases }\end{array}$ & M14 & $\begin{array}{l}\text { Matrigel invasion assay, } \\
\text { Integrin-mediated binding } \\
\text { assays }\end{array}$ & Glynn et al., 2008 [259] \\
\hline & $\begin{array}{l}\text { (1S,7S,8S,8aR)-8-(2-((2R,4R)-- } \\
\text { 4-hydroxy-6-oxotetrahydro- } \\
\text { 2H-pyran-2-yl)ethyl)-7- } \\
\text { methyl-1,2,3,7,8,8a- } \\
\text { hexahydronaphthalen-1-yl } \\
\text { (S)-2-methylbutanoate } \\
\text { (73573-88-3) }\end{array}$ & Penicillium citrinum ** & & & & HT144 & & \\
\hline & $\begin{array}{c}\text { (1S,3R,7S, 8S,8aR)-8-(2- } \\
\text { ((2S,4R)-4-hydroxy-6- } \\
\text { oxotetrahydro-2H-pyran-2- } \\
\text { yl)ethyl)-3,7-dimethyl- } \\
\text { 1,2,3,7,8,8a- } \\
\text { hexahydronaphthalen-1-yl } \\
\text { 2,2-dimethylbutanoate } \\
\text { (79902-63-9) }\end{array}$ & Aspergillus terreus & & & & SK-MEL-28 & & \\
\hline \multicolumn{9}{|c|}{ Macrosphelides (MSs) } \\
\hline & $\begin{array}{c}\text { (4S, } \mathrm{SE}, 9 \mathrm{R}, 10 \mathrm{~S}, 13 \mathrm{E}, 15 \mathrm{R}, 16 \mathrm{~S})- \\
\text { 9,15-dihydrox-4, } 10,16- \\
\text { trimethyl-1,5,11- } \\
\text { trioxacyclohexadeca-7,13- } \\
\text { diene-2,6,12-trione } \\
(172923-77-2)\end{array}$ & $\begin{array}{l}\text { Microsphaeropsis sp. } \\
\text { FO-5050 (soil) }\end{array}$ & $\begin{array}{l}\text { Inhibition of HL-60 cell } \\
\text { adhesion to HUVEC }\end{array}$ & B & $\begin{array}{l}\text { Blocking the binding of } \\
\text { SLex to ELAM- } 1\end{array}$ & HL-60 & Cell adhesion assay & Hayashi et al., 1995 [260 \\
\hline & $\begin{array}{c}\text { (4S,7E,9R,10S,13E,16S)-9- } \\
\text { hydroxy-4,10,16-trimethyl- } \\
\text { 1,5,11-trioxacyclohexadeca- } \\
\text { 7,13-diene-2,6,12,15- } \\
\text { tetraone } \\
(172923-78-3)\end{array}$ & & & & & HUVEC & & \\
\hline
\end{tabular}


Table 11. Cont.

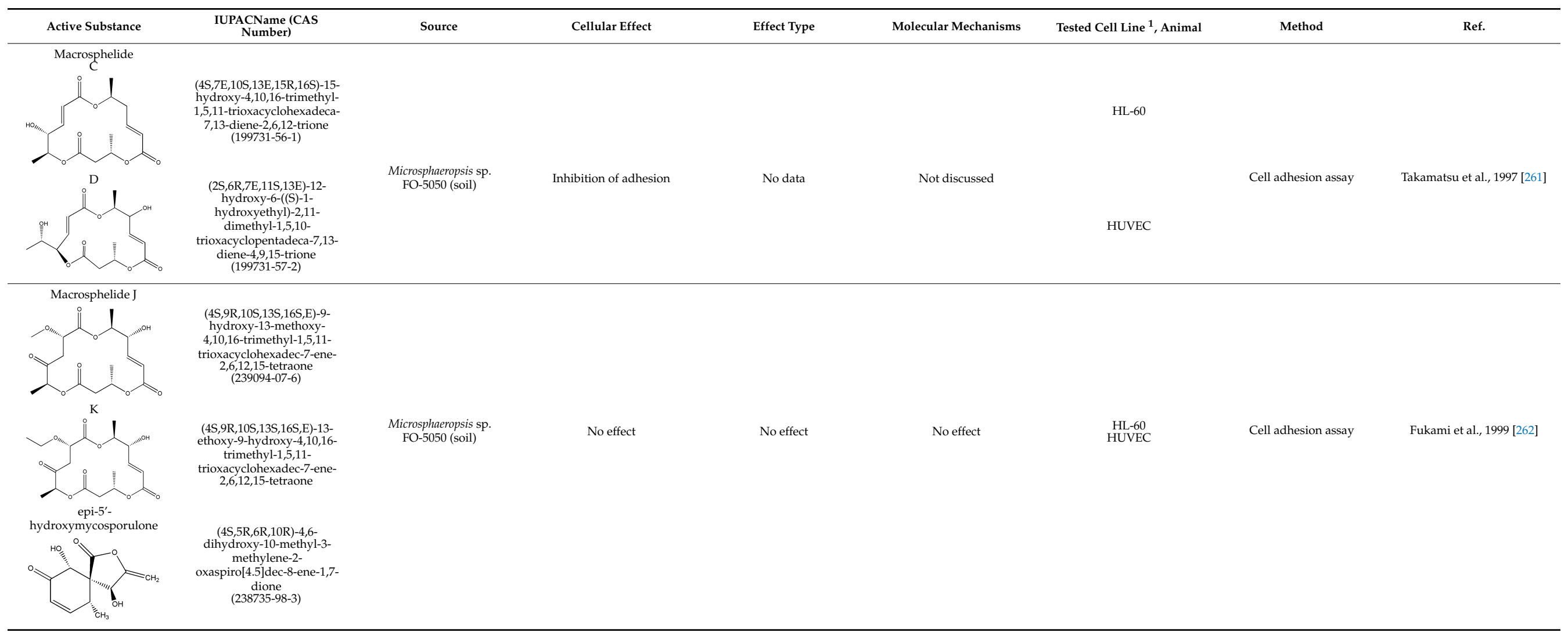


Table 11. Cont.

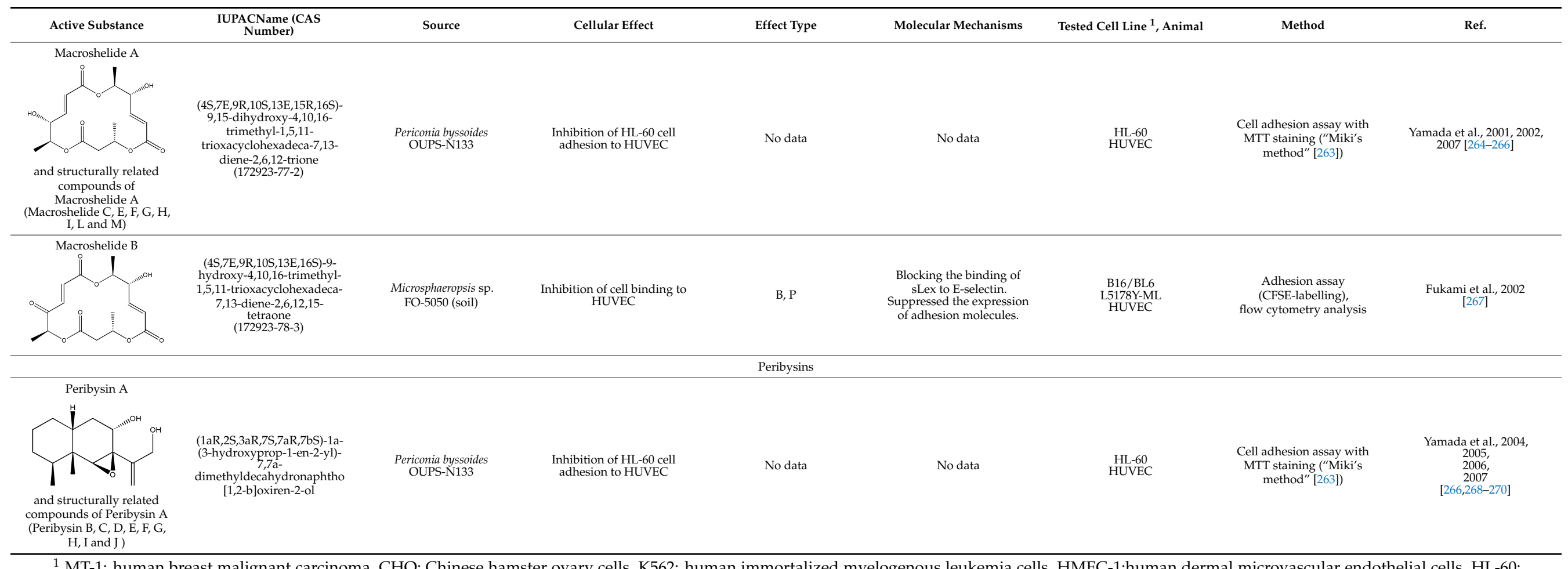

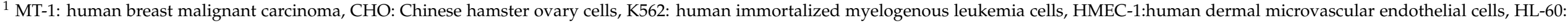

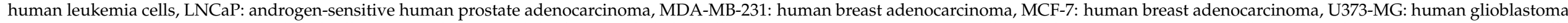

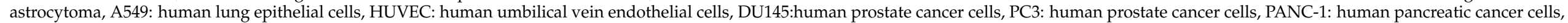

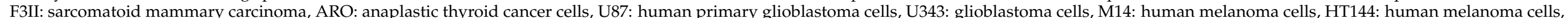

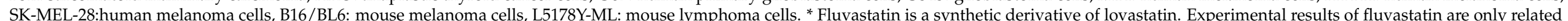

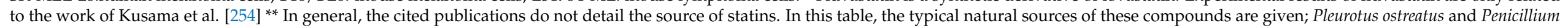
citrinum. In the case of lovastatin, Aspergillus terreus is a main source as well. 


\section{SARS-CoV-2 and Possible Treatments with Herbal Extracts}

A novel coronavirus (nCoV) started infecting humans since late 2019. The pathogen is called "Severe Acute Respiratory Syndrome-related Coronavirus 2" (SARS-CoV-2). It can cause a fatal respiratory disease, called Coronavirus disease 2019 (COVID-19), and acute respiratory distress syndrome (ARDS) as well [271]. The COVID-19 pandemic spread quickly inducing a worldwide problem, because the virus is highly contagious; transmission occurs presumably mainly via airborne droplets [271]. SARS-CoV-2 belongs to the genus Betacoronavirus of the large family of Coronaviridae [271]. Externally, the virus displays a corona-shaped layer of spikes that play a significant role in the infection process [272]. The virions are able to recover from the drastic mechanical perturbation imposed by atomic force microscopy [272]. The global structure is temperature-resistant, but the virion surface is denuded of spikes if heated [272]. These properties obviously influence the infectivity of the virus. The spike protein is a large glycoprotein trimer, which contributes to host receptor binding, cell tropism and pathogenesis [271]. A recent study showed that the surface of the native virion displays a dynamic brush owing to the rapid motions and flexibility of the spikes [272]. By binding host receptors, the virus genome penetrates into the cytoplasm of the host cell [271]. The angiotensin-converting enzyme II (ACE2) is a receptor for SARS-CoV-2, but it is suggested that the virus may use integrins too as receptors, binding to them through the conserved RGD motif $[50,51,273]$ ) present on the spike protein [271]. Members of the integrin family are commonly used as receptors by many other human viruses as well, and RGD is the minimal sequence required for binding [271]. Integrins have high expression in lungs and other vital organs whereas ACE2 is found to have negligible occurrence in the lungs [274]. Expression of integrins is high in lung cells (especially $\alpha \mathrm{V} \beta 6, \alpha \mathrm{V} \beta 8, \alpha 5 \beta 1$ ) and the ICAM- 1 . Thus, the high infectivity of the virus may be at least partly due to the RGD-integrin-mediated cell-adhesive property [274]. Phosphorylation sites on the spike protein induce Tyr, PKC and cAMP signaling pathways, which activate calcium ion channels or get activated by calcium [274]. Thus the RGD-integrin interaction clearly occurs in a calcium-dependent manner [274]. This interaction may then unleash a "cytokine storm" due to TNF $\alpha$ and IL-6 activation [274]. The lowering of divalent ion concentrations in the lungs by pulmonary EDTA chelation therapy may inhibit virus-host attachment [274]. Glycans may have multiple roles during viral entry [275]. Inhibition of N-glycan biosynthesis was shown to enhance spike protein proteolysis, leading to a decrease of receptor-binding domain presentation on the virus [275]. Thus, another idea for treatment is to administer chemical inhibitors of glycosylation [275]. Hence, although vaccines have already been developed and authorized for emergency use, extensive research work and brainstorming continue for the development of future drugs against SARS-CoV-2 (Figure 9).

Already-existing synthetic drugs (favipiravir, ivermectin, remdesivir, among others) have been shown to be effective for treatment, but the application of these drugs may have direct or indirect side effects (for example, pain, liver problems, allergy, etc.) [276]. Plants are an abundant source of natural antiviral compounds that may be an effective option, because most of them are safer compared to synthetic drugs, although there are exceptions [276]. Some of these metabolites have protective effects against different microbes; however, the role of most metabolites still remains unknown for us. Bhuiyan et al. created a large collection of antiviral compounds from 219 medicinal plants [276], from which, it can be inferred that polyphenols work against coronaviruses by actuating or inhibiting cellular signaling pathways or inhibiting 3-chymotripsin-like protease $\left(3 \mathrm{CL}^{\mathrm{pro}}\right)$ and papainlike protease (PL ${ }^{\mathrm{pro}}$ ) [276]. Polyphenol compounds from Broussonetia papyrifera, Sambucus and Pelargonium, and flavonoid-type compounds (quercetin, apigenin) showed activity against human coronavirus [276,277]. Different types of alkaloids (for example tylophorine, 7-methoxy cryptopleurine, etc.) have anti-SARS activity by inhibiting protease and RNA and protein synthesis, and chloroquine has been reported to have anti-SARS-CoV-2 activity [276]. Saponins (amphipatic triterpenes) showed antiviral effects against a lot of viruses (Influenza virus, Dengue virus, rotaviruses, among others) [276,278]. Among triterpenes, 
ginkgolide A can strongly inhibit the SARS-CoV-2 protease [276], and glycyrrhizin was found to be effective against influenza [278]. In the case of SARS-CoV-2, glycyrrhizin was found to have the highest binding affinity with the viral S protein $[276,279]$, but curcumin, apigenin and chrisophanol also bind to this part of the virus according to in silico molecular docking [279]. In a recent study, EGCG from green tea beverage was shown to inhibit infection of live virus and its variants by inhibiting spike binding to ACE2 receptor [280].

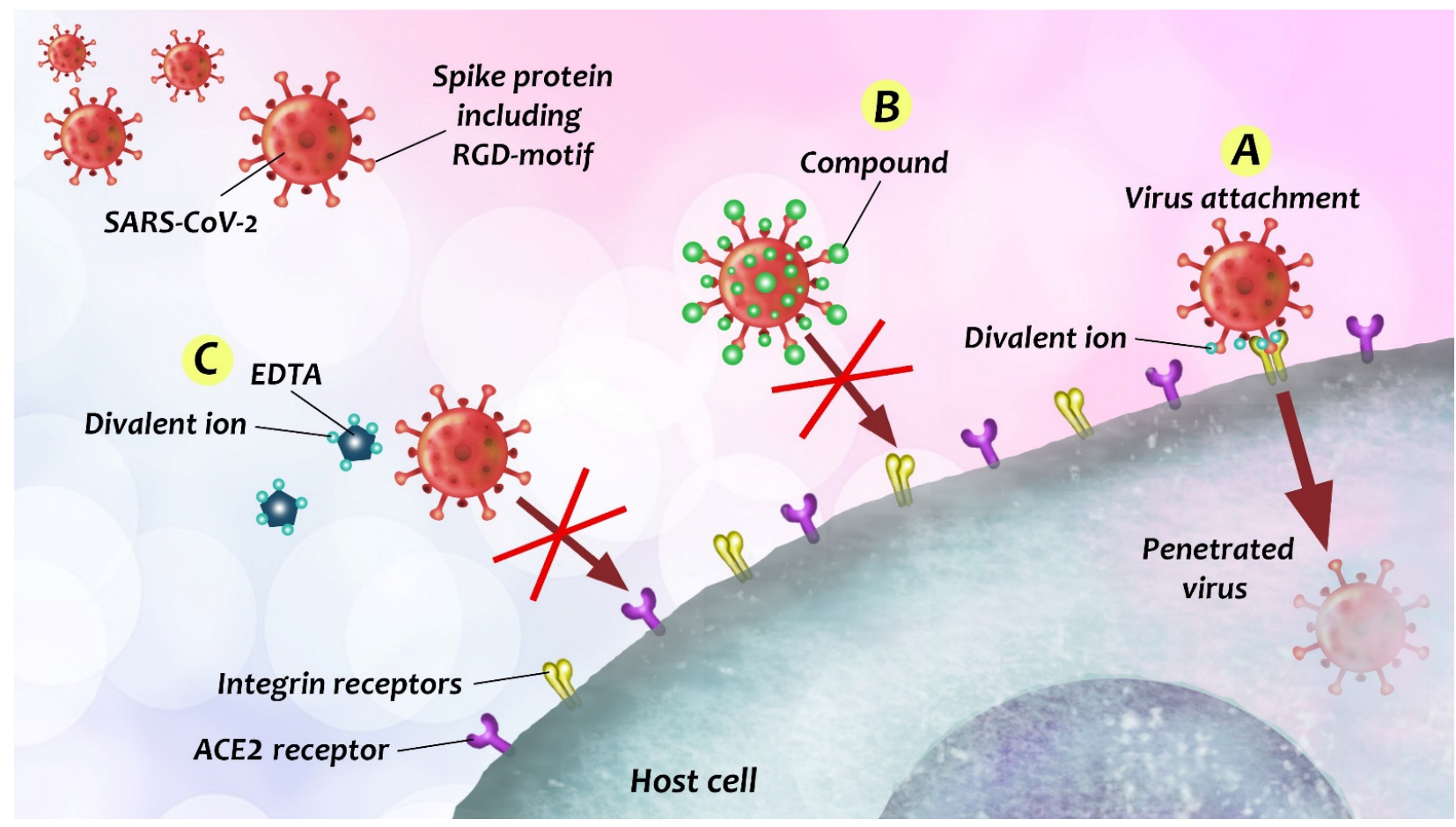

Figure 9. Schematic illustration of SARS-CoV-2 attachment and two possible examples of ways to inhibit this process. (A) Virus can attach to ACE2 receptor or integrins of the host cell. RGD-integrin interaction occurs in calcium-dependent manner [274]. As the result of the process, the virus penetrates into the cell and starts to copy itself. (B) Several compounds bind to the spike protein or even may alter it [275] and prevent virus-receptor attachment. (C) Lowering divalent ion concentrations in the lungs with pulmonary EDTA chelation therapy may inhibit virus-host interaction [274].

It should be noted that the risk factors for a severe course of COVID-19 in intensive care unit patients are chronic obstructive pulmonary disease, renal dysfunction, hypertension, diabetes mellitus and coronary heart disease. Elderly adults and patients with chronic illnesses and obesity are vulnerable [278]. There is preliminary evidence that nutrientrelated disorders are associated with greater susceptibility to infection [278].

Herbal remedies have a potentially preventive effect, mainly acting through supporting the immune system, for example Astragalus membranaceus or Echinacea purpurea [277]. Clinical studies showed that extracts from Pelargonium sidoides, Sambucus nigra and Cistus incanus are effective treatments of infectious respiratory illnesses [277,278]. Kalus et al., a decade before the COVID-19 pandemic, showed that Cistus incanus extract significantly decreased the symptoms of 160 patients with infections of the upper respiratory tract (caused by bacteria, influenza, and other viruses) and the level of C-reactive protein inflammatory marker was also decreased [281]. EGCG green tea polyphenol was shown to bind to the hemagglutinin of influenza virus [281] as well, implying that regular consumption of green tea should decrease the influenza infection rate, too [278]. In summary, consuming extracts of herbs, vegetables and fruits improve overall health due to their phytochemicals and nutrients, and these compounds may prevent or attenuate the symptoms of COVID-19. 


\section{Conclusions}

Most investigations into the effect of natural products on cellular adhesion are focused on the adhesion molecules belonging to the immunoglobulin superfamily of CAMs (ICAM1 and VCAM-1), and selectins and integrins [5]. These molecules are implicated in several widespread diseases, such as various types of inflammation, rheumatism, atherosclerosis and cancer. Metabolites obtained from plants, fungi and venoms may offer therapeutic potential by regulating adhesion molecules, generally down-regulation [5]. We summarized natural metabolites having diverse structures, which influence cellular adhesion and migration by modulation of adhesion molecules. The reported effects of natural products, either presented to model cell systems as complex extracts or as purified active principles, generally manifest themselves as: (i) inhibition of cell-cell adhesion (i.e., circulating to endothelial cells); and (ii) a general anti-inflammatory effect. The mechanism of (i) is either the blocking of specific adhesion sites (such as the RGD motif and/or its binding complement) on the cell surface (the group of mechanisms labeled B-blocking adhesion receptors on the surface of immune or tissue cells, or motifs in the ECM), or the downregulation of the cell adhesion molecules (the group of mechanisms labeled $\mathrm{P}$-inhibiting the dephosphorylation, translocation or binding of certain factors). The latter group is often effected by inhibition of signaling pathways involving NF- $\mathrm{kB}$. The mechanism of (ii) is by suppressing ROS, achieved by the sacrificial oxidation of the natural product. To map the properties and effects of natural compounds, "classical" labeling techniques have been applied to monitor cellular adhesion and movement. New label-free methods can provide more information (especially kinetic information) about the effects of extracts more sensitively and conveniently without using any cell physiology-altering dyes or other labels. In this review, the preparation method of natural compounds was summarized and the natural product banks were mentioned as well. We systematized recent studies about natural compounds referring to their effects on cell adhesion and movement; the active substances were categorized based on their origin (floral, faunal or fungal). From these collected results it can be clearly seen that applying natural compounds can be a cure against tumors and inflammatory diseases, but more clinical tests would be desirable. Synthetically modified versions of the substances can be also used to cure illness. Finding new, still unknown natural compounds and to map the exact effects of already known extracts from traditional medicine are both important to create new, better, and more effective therapeutic drugs. Some plant extracts showed antiviral activity on SARS-CoV-2 as well, thus natural compounds may be used to attenuate or even prevent the symptoms of COVID-19 as well.

Our review aimed at collecting evidence in order to answer a specific research question [282], namely the role of natural compounds in cellular adhesion and migration, including the characterization methods of these bioactive compounds. We have elucidated the main points of interest (definition of natural compounds and their isolation, adhesion and migration process, effects on cell viability, invasive and non-invasive assays, label free techniques) with inclusion and exclusion criteria. We have made a careful and systematic search of the literature, using the following keywords: natural compound of plant, fungi and other origin, cell adhesion, migration, motility, movement, CAM, integrin, cancer cell, stimulation, inflammation, viability, cytotoxicity, flow cytometry, dyes, label-free, biosensors, preparation, isolation, intracellular pathogens SARS-CoV-2. Approximately 280 relevant paper wereselected. Very recent (2021) and old references (articles from the 1970s and even from 1962) were evaluated. Our criteria were that the compound must be a natural one (i.e., natural origin), with effect on cell adhesion and/or migration.

Author Contributions: Conceptualization: B.P., S.B., G.M.K., I.B. and R.H. Preparation of tables: B.P., I.S. Literature searching and writing: all authors. Visualization and figures: B.P., S.B. and I.S. All authors have read and agreed to the published version of the manuscript.

Funding: This research was funded by the Hungarian Academy of Sciences [Lendület (Momentum) Program], the National Research, Development and Innovation Office (NKFIH) [ERC_HU, PD 131543 
and KKP_19 Programs] and grant OTKA (number 135712). S.B., I.B. and G.M.K. acknowledge the support of the ELTE Thematic Excellence Programme supported by the Hungarian Ministry for Innovation and Technology and ELTE Thematic Excellence Programme 2020 supported by the National Research, Development and Innovation Office (TKP2020-IKA-05). I.S., S.B, I.B. and G.M.K. thank for the support of grant EFOP-1.8.0-VEKOP-17-2017-00001.

Institutional Review Board Statement: Not applicable.

Informed Consent Statement: Not applicable.

Data Availability Statement: All relevant data are available in the manuscript.

Conflicts of Interest: The authors declare no conflict of interest.

\section{References}

1. Peter, B.; Bosze, S.; Horvath, R. Biophysical characteristics of living cells exposed to the green tea polyphenol epigallocatecin3-gallate (EGCg): Review of recent advances from molecular mechanisms to clinical trials. Eur. Biophys. J. 2016, 46, 1-35. [CrossRef]

2. Ling, S.; Nheu, L.; Dai, A.; Guo, Z.; Komesaroff, P. Effects of four medicinal herbs on human vascular endothelial cells in culture. Int. J. Cardiol. 2008, 128, 350-358. [CrossRef] [PubMed]

3. Kinghorn, A.D.; De Blanco, E.J.C.; Chai, H.; Orjala, J.; Farnsworth, N.R.; Soejarto, D.D.; Oberlies, N.H.; Wani, M.C.; Kroll, D.J.; Pearce, C.J.; et al. Discovery of anticancer agents of diverse natural origin. Pure Appl. Chem. 2009, 81, 1051-1063. [CrossRef]

4. Gumbiner, B.M. Cell adhesion: The molecular basis of tissue architecture and morphogenesis. Cell 1996, 84, 345-357. [CrossRef]

5. Spelman, K.; Aldag, R.; Hamman, A.; Kwasnik, E.M.; Mahendra, M.A.; Obasi, T.M.; Morse, J.; Williams, E.J. Traditional herbal remedies that influence cell adhesion molecule activity. Phytother. Res. 2011, 25, 473-483. [CrossRef]

6. Goldstein, I.M.; Malmsten, C.L.; Samuelsson, B.; Weissmann, G. Prostaglandins, thromboxanes, and polymorphonuclear leukocytes. Inflammation 1977, 2, 309-317. [CrossRef] [PubMed]

7. Chang, D.-M.; Kuo, S.-Y.; Lai, J.-H.; Chang, M.-L. Effects of anti-rheumatic herbal medicines on cellular adhesion molecules. Ann. Rheum. Dis. 1999, 58, 366-371. [CrossRef] [PubMed]

8. Bevilacqua, M.P.; Pober, J.S.; Wheeler, M.E.; Cotran, R.S.; Gimbrone, M.A. Interleukin 1 acts on cultured human vascular endothelium to increase the adhesion of polymorphonuclear leukocytes, monocytes, and related leukocyte cell lines. J. Clin. Investig. 1985, 76, 2003-2011. [CrossRef]

9. Cronstein, B.N.; Weissmann, G. The adhesion molecules of inflammation. Arthritis Rheum. 1993, 36, 147-157. [CrossRef]

10. Hynes, R.O. Integrins: Bidirectional, Allosteric Signaling Machines. Cell 2002, 110, 673-687. [CrossRef]

11. Bevilacqua, M.P. Endothelial-leukocyte cellular adhesion molecules. Annu. Rev. Immunol. 1993, 11, 767-804. [CrossRef]

12. Grober, J.S.; Bowen, B.L.; Ebling, H.; Athey, B.; Thompson, C.B.; Fox, D.A.; Stoolman, L.M. Monocyte-endothelial adhesion in chronic rheumatoid arthritis: In situ detection of selectin and integrin-dependent interactions. J. Clin. Investig. 1993, 91, 2609-2619. [CrossRef]

13. Kawasaki, K.; Muroyama, K.; Yamamoto, N.; Murosaki, S. A hot water extract of Curcuma longa inhibits adhesion molecule protein expression and monocyte adhesion to TNF-alpha-stimulated human endothelial cells. Biosci. Biotechnol. Biochem. 2015, 79, 1654-1659. [CrossRef]

14. Ramadori, G.; Moriconi, F.; Malik, I.; Dudas, J. Physiology and pathophysiology of liver inflammation, damage and repair. J. Physiol. Pharmacol. 2008, 59, 107-117.

15. Parsons, J.T.; Horwitz, A.R.; Schwartz, M.A. Cell adhesion: Integrating cytoskeletal dynamics and cellular tension. Nat. Rev. Mol. Cell Biol. 2010, 11, 633-643. [CrossRef]

16. Mezu-Ndubuisi, O.J.; Maheshwari, A. The role of integrins in inflammation and angiogenesis. Pediatr. Res. 2020, 89, 1619-1626. [CrossRef]

17. Yue, J.; Zhang, K.; Chen, J.F. Role of integrins in regulating proteases to mediate extracellular matrix remodeling. Cancer Microenviron. 2012, 5, 275-283. [CrossRef]

18. Papoutsi, Z.; Kassi, E.; Chinou, I.; Halabalaki, M.; Skaltsounis, L.A.; Moutsatsou, P. Walnut extract (Juglans regia L.) and its component ellagic acid exhibit anti-inflammatory activity in human aorta endothelial cells and osteoblastic activity in the cell line KS483. Br. J. Nutr. 2008, 99, 715-722. [CrossRef] [PubMed]

19. Tang, P.; Hung, M.C.; Klostergaard, J. Human pro-tumor necrosis factor is a homotrimer. Biochemistry 1996, $35,8216-8225$. [CrossRef]

20. Spelman, K.; Burns, J.J.; Nichols, D.; Winters, N.; Ottersberg, S.; Tenborg, M. Modulation of Cytokine Expression by Traditional Medicines: A Review of Herbal Immunomodulators. Altern. Med. Rev. 2006, 11, 128-150.

21. Carluccio, M.A.; Siculella, L.; Ancora, M.A.; Massaro, M.; Scoditti, E.; Storelli, C.; Visioli, F.; Distante, A.; De Caterina, R. Olive oil and red wine antioxidant polyphenols inhibit endothelial activation: Antiatherogenic properties of Mediterranean diet phytochemicals. Arterioscler. Thromb. Vasc. Biol. 2003, 23, 622-629. [CrossRef]

22. Zhang, W.-J.; Hufnag, P.; Binder, B.R.; Wojta, J. Antiinflammatory activity of astragaloside IV is mediated by inhibition of NF- $\mathrm{kB}$ activation and adhesion molecule expression. Thromb. Haemost. 2003, 90, 904-914. [CrossRef] 
23. Tao, X.; Lipsky, P.E. The Chinese anti-inflammatory and immunosuppressive herbal remedy Tripterygium Wilfordii Hook F. Rheum. Dis. Clin. N. Am. 2000, 26, 29-50. [CrossRef]

24. Iademarco, M.F.; McQuillan, J.J.; Rosen, G.D.; Dean, D.C. Characterization of the promoter for vascular cell adhesion molecule-1 (VCAM-1). J. Biol. Chem. 1992, 267, 16323-16329. [CrossRef]

25. Schindler, U.; Baichwal, V.R. Three NF-kappa B binding sites in the human E-selectin gene required for maximal tumor necrosis factor alpha-induced expression. Mol. Cell. Biol. 1994, 14, 5820-5831. [CrossRef]

26. Collins, T.; Read, M.A.; Neish, A.S.; Whitley, M.Z.; Thanos, D.; Maniatis, T. Transcriptional regulation of endothelial cell adhesion molecules: NF-kappa B and cytokine-inducible enhancers. FASEB J. 1995, 10, 899-909. [CrossRef]

27. Voraberger, G.; Schäfer, R.; Stratowa, C. Cloning of the human gene for intercellular adhesion molecule 1 and analysis of its $5^{\prime}-$ regulatory region. Induction by cytokines and phorbol ester. J. Immunol. 1991, 147, 2777-2786.

28. Tak, P.P.; Firestein, G.S. NF-kB: A key role in inflammatory diseases. J. Clin. Investig. 2001, 107, 7-11. [CrossRef] [PubMed]

29. Baldwin, A.S., Jr. The NF-кB and I kappa B proteins: New discoveries and insights. Annu. Rev. Immunol. 1996, 14, 649-683. [CrossRef]

30. Kurucz, I.; Peter, B.; Prosz, A.; Szekacs, I.; Erdei, A.; Horvath, R. Label-free optical biosensor for on-line monitoring the integrated response of human B cells upon the engagement of stimulatory and inhibitory immune receptors. Sens. Actuators B 2017, 240, 528-535. [CrossRef]

31. Erdei, A.; Sándor, N.; Szilvia, B.M.; Kremlitzka, M.; Bajtay, Z. The versatile functions of complement C3-derived ligands. Immunol. Rev. 2016, 274, 127-140. [CrossRef]

32. Gorfu, G.; Rivera-Nieves, J.; Ley, K. Role of $\beta 7$ integrins in intestinal lymphocyte homing and retention. Curr. Mol. Med. 2009, 9 , 836-850. [CrossRef]

33. Caswell, P.T.; Vadrevu, S.; Norman, J.C. Integrins: Masters and slaves of endocytic transport. Nat. Rev. Mol. Cell Biol. 2009, 10, 843-853. [CrossRef]

34. Liu, X.; Wang, W.; Song, G.; Wei, X.; Zeng, Y.; Han, P.; Wang, D.; Shao, M.; Wu, J.; Sun, H.; et al. Astragaloside IV ameliorates diabetic nephropathy by modulating the mitochondrial quality control network. PLoS ONE 2017, 12, e0182558. [CrossRef]

35. Date, R. Research review on the pharmacological effects of Astragaloside IV. Fundam. Clin. Pharmacol. 2017, 31, 17-36. [CrossRef]

36. Gui, D.; Huang, J.; Guo, Y.; Chen, J.; Chen, Y.; Xiao, W.; Liu, X.; Wang, N. Cytokine Astragaloside IV ameliorates renal injury in streptozotocin-induced diabetic rats through inhibiting NF- j B-mediated inflammatory genes expression. Cytokine 2013, 61, 970-977. [CrossRef]

37. Wang, Z.S.; Xiong, F.; Xie, X.H.; Chen, D.; Pan, J.H.; Cheng, L. Astragaloside IV attenuates proteinuria in streptozotocin-induced diabetic nephropathy via the inhibition of endoplasmic reticulum stress. Nephrology 2015, 16, 44. [CrossRef]

38. Chen, J.; Chen, Y.; Luo, Y.; Gui, D.; Huang, J.; He, D. Astragaloside IV ameliorates diabetic nephropathy involving protection of podocytes in streptozotocin induced diabetic rats. Eur. J. Pharmacol. 2014, 736, 86-94. [CrossRef]

39. Cheng, S.; Wu, Y.; Huang, W.; Pang, J.S. Cytokine Anti-in fl ammatory property of quercetin through downregulation of ICAM-1 and MMP-9 in TNF- $\alpha$-activated retinal pigment epithelial cells. Cytokine 2019, 116, 48-60. [CrossRef]

40. Lee, J.; Zhou, H.Y.; Cho, S.Y.; Kim, Y.S.; Lee, Y.S.; Jeong, C.S. Anti-inflammatory Mechanisms of Apigenin: Inhibition of Cyclooxygenase-2 Expression, Adhesion of Monocytes to Human Umbilical Vein Endothelial Cells, and Expression of Cellular Adhesion Molecules. Arch. Pharm. Res. 2007, 30, 1318-1327. [CrossRef] [PubMed]

41. Journal, A.I.; Song, Y.; Tian, X.; Wang, X.; Feng, H. Vascular protection of salicin on IL-1 $\beta$-induced endothelial inflammatory response and damages in retinal endothelial cells. Artif. Cells Nanomed. Biotechnol. 2019, 47, 1995-2002. [CrossRef]

42. Rho, M.; Kwon, O.E.; Kim, K.; Lee, S.W.; Chung, M.Y.; Kim, Y.H.; Hayashi, M.; Lee, H.S.; Kim, Y. Inhibitory Effects of Manassantin A and B Isolated from the Roots of Saururus chinensis on PMA-Induced ICAM-1 Expression. Planta Med. 2003, 69, 1147-1149.

43. Choi, Y.; Jin, H.; Park, S.; Chung, J.; Lee, H.; Oh, S.; Kim, B.; Kim, J.; Chung, H.; Yu, B.; et al. Inhibition of endothelial cell adhesion by the new anti-inflammatory agent $\alpha$-iso-cubebene. Vasc. Pharmacol. 2009, 51, 215-224. [CrossRef]

44. Jiang, C.; Li, J.; Liu, F.; Wu, T.A.O.; Yu, M.; Xu, H. Andrographolide Inhibits the Adhesion of Gastric Cancer Cells to Endothelial Cells by Blocking E-selectin Expression. Anticancer Res. 2007, 2448, 2439-2447.

45. Wu, S.; Xu, H.; Peng, J.; Wang, C.; Jin, Y.; Liu, K. Biochimie Potent anti-inflammatory effect of dioscin mediated by suppression of TNF- a -induced VCAM-1, ICAM-1and EL expression via the NF- $\mathrm{k}$ B pathway. Biochimie 2015, 110, 62-72. [CrossRef]

46. Kumar, S.; Arya, P.; Mukherjee, C.; Singh, B.K.; Singh, N.; Parmar, V.S.; Prasad, A.K.; Ghosh, B. Novel aromatic ester from Piper longum and its analogues inhibit expression of cell adhesion molecules on endothelial cells. Biochemistry 2005, 44, 15944-15952. [CrossRef]

47. Wu, Q.P.; Xie, Y.Z.; Li, S.Z.; La Pierre, D.P.; Deng, Z.; Chen, Q.; Li, C.; Zhang, Z.; Guo, J.; Wong, C.K.A.; et al. Tumour cell adhesion and integrin expression affected by Ganoderma lucidum. Enzyme Microb. Technol. 2006, 40, 32-41. [CrossRef]

48. Wang, L.; Ling, Y.; Chen, Y.; Li, C.L.; Feng, F.; You, Q.D.; Lu, N.; Guo, Q.L. Flavonoid baicalein suppresses adhesion, migration and invasion of MDA-MB-231 human breast cancer cells. Cancer Lett. 2010, 297, 42-48. [CrossRef]

49. Jang, J.H.; Yang, E.S.; Min, K.-J.; Kwon, T.K. Inhibitory effect of butein on tumor necrosis factor- $\alpha$-induced expression of cell adhesion molecules in human lung epithelial cells via inhibition of reactive oxygen species generation, NF- $\mathrm{kB}$ activation and Akt phosphorylation. Int. J. Mol. Med. 2012, 30, 1357-1364. [CrossRef] 
50. Peter, B.; Farkas, E.; Forgacs, E.; Saftics, A.; Kovacs, B.; Kurunczi, S.; Szekacs, I.; Csampai, A.; Bosze, S.; Horvath, R. Green tea polyphenol tailors cell adhesivity of RGD displaying surfaces: Multicomponent models monitored optically. Nat. Publ. Gr. 2017, 7, 42220. [CrossRef]

51. Szekacs, I.; Orgovan, N.; Peter, B.; Kovacs, B.; Horvath, R. Receptor specific adhesion assay for the quantification of integrinligand interactions in intact cells using a microplate based, label-free optical biosensor. Sens. Actuators B Chem. 2018, 256, 729-734. [CrossRef]

52. Cox, D.; Brennan, M.; Moran, N. Integrins as therapeutic targets: Lessons and opportunities. Nat. Rev. Drug Discov. 2010, 9, 804-820. [CrossRef] [PubMed]

53. Ley, K.; Rivera-Nieves, J.; Sandborn, W.J.; Shattil, S. Integrin-based therapeutics: Biological basis, clinical use and new drugs. Nat. Rev. Drug Discov. 2016, 15, 173-183. [CrossRef]

54. McLane, M.A.; Sanchez, E.E.; Wong, A.; Paquette-Straub, C.; Perez, J.C. Disintegrins. Curr. Drug Targets Cardiovasc. Haematol. Disord. 2004, 4, 327-355. [CrossRef] [PubMed]

55. Wu, W.-B.; Peng, H.-C.; Huang, T.-F. Disintegrin causes proteolysis of $\beta$-catenin and apoptosis of endothelial cells: Involvement of cell—cell and cell-ECM interactions in regulating cell viability. Exp. Cell Res. 2003, 286, 115-127. [CrossRef]

56. Chang, Y.; Shiu, J.; Huang, C.; Chen, Y.; Chen, C.; Chang, Y.; Chuang, W. Effects of the RGD loop and C-terminus of rhodostomin on regulating integrin $\alpha \mathrm{IIb} \beta 3$ recognition. PLoS ONE 2017, 12, e0175321. [CrossRef]

57. McColl, J.; Horvath, R.; Yakubov, G.E.; Ramsden, J.J. Surface rearrangement of adsorbed EGCG-mucin complexes on hydrophilic surfaces. Int. J. Biol. Macromol. 2017, 95, 704-712. [CrossRef]

58. Habtemariam, S. Cistifolin, an Integrin-Dependent Cell Adhesion Blocker from the Anti- Rheumatic Herbal Drug, Gravel Root (Rhizome of Eupatorium purpureum). Planta Med. 1998, 64, 683-685. [CrossRef]

59. Peter, B.; Ungai-Salanki, R.; Szabó, B.; Nagy, A.G.; Szekacs, I.; Bösze, S.; Horvath, R. High-Resolution Adhesion Kinetics of EGCG-Exposed Tumor Cells on Biomimetic Interfaces: Comparative Monitoring of Cell Viability Using Label-Free Biosensor and Classic End-Point Assays. ACS Omega 2018, 3, 3882-3891. [CrossRef]

60. Cheung, K.C.; Di Berardino, M.; Schade-Kampmann, G.; Hebeisen, M.; Pierzchalski, A.; Bocsi, J.; Mittag, A.; Tárnok, A. Microfluidic impedance-based flow cytometry. Cytom. Part A 2010, 77, 648-666. [CrossRef]

61. Wang, P.; Henning, S.M.; Heber, D. Limitations of MTT and MTS-based assays for measurement of antiproliferative activity of green tea polyphenols. PLoS ONE 2010, 5, e10202. [CrossRef] [PubMed]

62. Niles, A.L.; Moravec, R.A.; Riss, T.L. In vitro viability and cytotoxicity testing and same-well multi-parametric combinations for high throughput screening. Curr. Chem. Genom. 2009, 3, 33-41. [CrossRef]

63. Mahto, S.K.; Chandra, P.; Rhee, S.W. In vitro models, endpoints and assessment methods for the measurement of cytotoxicity. Toxicol. Environ. Health Sci. 2010, 2, 87-93. [CrossRef]

64. Menyhárt, O.; Harami-Papp, H.; Sukumar, S.; Schäfer, R.; Magnani, L.; de Barrios, O.; Győrffy, B. Guidelines for the selection of functional assays to evaluate the hallmarks of cancer. Biochim. Biophys. Acta Rev. Cancer 2016, 1866, 300-319. [CrossRef]

65. Markossian, S.; Grossman, A.; Brimacombe, K.; Arkin, M.; Auld, D.; Austin, C.P.; Baell, J.; Chung, T.D.Y.; Coussens, N.P.; Dahlin, J.L.; et al. (Eds.) Assay Guidance Manual; Eli Lilly \& Company and the National Center for Advancing Translational Sciences: Bethesda, MD, USA, 2004; p. 540958. Available online: https://www.ncbi.nlm.nih.gov/books/NBK540958/ (accessed on 23 November 2021).

66. Feoktistova, M.; Geserick, P.; Leverkus, M. Crystal violet assay for determining viability of cultured cells. Cold Spring Harb. Protoc. 2016, 2016, 343-346. [CrossRef]

67. Lee, Y.; Chen, M.; Lee, J.D.; Zhang, J.; Lin, S.; Fu, M.; Chen, H.; Ishikawa, T.; Chiang, S.; Katon, J.; et al. HHS Public Access through inhibition of a MYC-WWP1 inhibitory pathway. Science 2020, 364, 1-40. [CrossRef]

68. Vasan, N.; Razavi, P.; Johnson, J.L.; Shao, H.; Shah, H.; Antoine, A.; Ladewig, E.; Gorelick, A.; Lin, T.Y.; Toska, E.; et al. Double PIK3CA mutations in cis increase oncogenicity and sensitivity to PI3Ka inhibitors. Science 2019, 366, 714-723. [CrossRef] [PubMed]

69. Johnston, G. Automated handheld instrument improves counting precision across multiple cell lines. Biotechniques 2010, 48, 325-327. [CrossRef]

70. Strober, W. Trypan Blue Exclusion Test of Cell Viability. Curr. Protoc. Immunol. 2001, 21, A-3B. [CrossRef]

71. Aslantürk, S.; Çelik, T.A. Antioxidant activity and anticancer effect of Vitex agnus-castus L. (Verbenaceae) seed extracts on MCF-7 breast cancer cells. Caryologia 2013, 66, 257-267. [CrossRef]

72. Stone, V.; Johnston, H.; Schins, R.P.F. Development ofin vitrosystems for nanotoxicology: Methodological considerations. Crit. Rev. Toxicol. 2009, 39, 613-626. [CrossRef]

73. Yip, D.K.; Auersperg, N. The dye-exclusion test for cell viability: Persistence of differential staining following fixation. In Vitro J. Tissue Cult. Assoc. 1972, 7, 323-329. [CrossRef]

74. Ruben, R.L. Cell culture for testing anticancer compounds. In Advances in Cell Culture; Marqmarosh, K., Sato, G.H., Eds.; Academic Press: San Diego, CA, USA, 1988; Volume 6, pp. 161-188.

75. Kim, S.I.; Kim, H.J.; Lee, H.J.; Lee, K.; Hong, D.; Lim, H.; Cho, K.; Jung, N.; Yi, Y.W. Application of a non-hazardous vital dye for cell counting with automated cell counters. Anal. Biochem. 2016, 492, 8-12. [CrossRef]

76. Marmion, D.M. Handbook of U.S. Colortants for Foods, Drugs, and Cosmetics; Wiley Interscience: New York, NY, USA, 1979. 
77. Aslantürk, Ö.; Çelik, T.; Karabey, B.; Karabey, F. Active Phytochemical Detecting, Antioxidant, Cytotoxic, Apoptotic Activities of Ethyl Acetate and Methanol Extracts of Galium aparine L. Br. J. Pharm. Res. 2017, 15, 1-16. [CrossRef]

78. Bopp, S.K.; Lettieri, T. Comparison of four different colorimetric and fluorometric cytotoxicity assays in a zebrafish liver cell line. BMC Pharmacol. 2008, 8, 8. [CrossRef] [PubMed]

79. Mosmann, T. Rapid colorimetric assay for cellular growth and survival: Application to proliferation and cytotoxicity assays. J. Immunol. Methods 1983, 65, 55-63. [CrossRef]

80. Berg, K.; Zhai, L.; Chen, M.; Kharazmi, A.; Owen, T.C. The use of a water-soluble formazan complex to quantitate the cell number and mitochondrial function of Leishmania major promastigotes. Parasitol. Res. 1994, 80, 235-239. [CrossRef]

81. Tominaga, H.; Ishiyama, M.; Ohseto, F.; Sasamoto, K.; Hamamoto, T.; Suzuki, K.; Watanabe, M. A water-soluble tetrazolium salt useful for colorimetric cell viability assay. Anal. Commun. 1999, 36, 47-50. [CrossRef]

82. Rotter, B.A.; Thompson, B.K.; Clarkin, S.; Owen, T.C. Rapid colorimetric bioassay for screening of fusarium mycotoxins. Nat. Toxins 1993, 1, 303-307. [CrossRef] [PubMed]

83. Buttke, T.M.; McCubrey, J.A.; Owen, T.C. Use of an aqueous soluble tetrazolium/formazan assay to measure viability and proliferation of lymphokine-dependent cell lines. J. Immunol. Methods 1993, 157, 233-240. [CrossRef]

84. Promega Corparation Technical Bulletin. CellTitre 96 AQueous Non-Radioactive Cell Proliferation Assay. 2006. Available online: https:/ / worldwide.promega.com/resources/protocols/technical-bulletins/0/celltiter-96-aqueous-nonradioactive-cellproliferation-assay-protocol/ (accessed on 23 November 2021).

85. Cory, A.H.; Owen, T.C.; Barltrop, J.A.; Cory, J.G. Use of an aqueous soluble tetrazolium/formazan assay for cell growth assays in culture. Cancer Comm. 1991, 3, 207-212. [CrossRef]

86. Riss, T.L.; Moravec, R.A. Comparison of MTT, XTT, and a novel tetrazolium compound MTS for in vitro proliferation and chemosensitivity assays. Mol. Biol. Cell 1992, 3, A184.

87. Scudiero, D.A.; Shoemaker, R.H.; Paull, K.D.; Monks, A.; Tierney, S.; Nofziger, T.H.; Currens, M.J.; Seniff, D.; Boyd, M.R. Evaluation of a Soluble Tetrazolium/Formazan Assay for Cell Growth and Drug Sensitivity in Culture Using Human and Other Tumor Cell Lines. Cancer Res. 1988, 48, 4827-4833. [PubMed]

88. Ishiyama, M.; Shiga, M.; Sasamoto, K.; Mizoguchi, M.; He, P. A new sulfonated tetrazolium salt that produces a high water-soluble formazan dye. Chem. Pharm. Bull. 1993, 41, 1118-1122. [CrossRef]

89. Decker, T.; Lohmann-Matthes, M.L. A quick and simple method for the quantitation of lactate dehydrogenase release in measurements of cellular cytotoxicity and tumor necrosis factor (TNF) activity. J. Immunol. Methods 1988, 115, 61-69. [CrossRef]

90. Schins, R.P.F.; Duffin, R.; Höhr, D.; Knaapen, A.M.; Shi, T.; Weishaupt, C.; Stone, V.; Donaldson, K.; Borm, P.J.A. Surface modification of quartz inhibits toxicity, particle uptake, and oxidative DNA damage in human lung epithelial cells. Chem. Res. Toxicol. 2002, 15, 1166-1173. [CrossRef]

91. Fotakis, G.; Timbrell, J.A. In vitro cytotoxicity assays: Comparison of LDH, neutral red, MTT and protein assay in hepatoma cell lines following exposure to cadmium chloride. Toxicol. Lett. 2006, 160, 171-177. [CrossRef] [PubMed]

92. Lappalanien, K.; Jaaskelainen, L.; Syrjanen, K.; Urtti, A.; Syrjanen, S. Comparison of cell proliferation and toxicity assays using two catronic liposomes. Pharm. Res. 1994, 11, 1127-1131. [CrossRef]

93. Skehan, P.; Storeng, R.; Scudiero, D.; Monks, A.; Mcmahon, J.; Vistica, D.; Warren, J.T.; Bokesch, H.; Kenney, S.; Boyd, M.R. New colorimetric cytotoxicity assay for anticancer-drug screening. J. Natl. Cancer Inst. 1990, 82, 1107-1112. [CrossRef]

94. Borenfreund, E.; Puerner, J.A. A simple quantitative procedure using monolayer cultures for cytotoxicity assays (HTD/NR-90). J. Tissue Cult. Methods 1985, 9, 7-9. [CrossRef]

95. Repetto, G.; del Peso, A.; Zurita, J.L. Neutral red uptake assay for the estimation of cell viability/ cytotoxicity. Nat. Protoc. 2008, 3, 1125-1131. [CrossRef]

96. Ringwood, A.H.; Conners, D.E.; Hoguet, J. Effects of natural and anthropogenic stressors on lysosomal destabilization in oysters Crassostrea virginica. Mar. Ecol. Prog. Ser. 1998, 166, 163-171. [CrossRef]

97. Geserick, P.; Hupe, M.; Moulin, M.; Wong, W.W.L.; Feoktistova, M.; Kellert, B.; Gollnick, H.; Silke, J.; Leverkus, M. Cellular IAPs inhibit a cryptic CD95-induced cell death by limiting RIP1 kinase recruitment. J. Cell Biol. 2009, 187, 1037-1054. [CrossRef]

98. Degterev, A.; Hitomi, J.; Germscheid, M.; Ch'en, I.L.; Korkina, O.; Teng, X.; Abbott, D.; Cuny, G.D.; Yuan, C.; Wagner, G.; et al. Identification of RIP1 kinase as a specific cellular target of necrostatins. Nat. Chem. Biol. 2008, 4, 313-321. [CrossRef]

99. Sun, L.; Wang, H.; Wang, Z.; He, S.; Chen, S.; Liao, D.; Wang, L.; Yan, J.; Liu, W.; Lei, X.; et al. Mixed lineage kinase domain-like protein mediates necrosis signaling downstream of RIP3 kinase. Cell 2012, 148, 213-227. [CrossRef]

100. Feoktistova, M.; Geserick, P.; Kellert, B.; Dimitrova, D.P.; Langlais, C.; Hupe, M.; Cain, K.; MacFarlane, M.; Häcker, G.; Leverkus, M. CIAPs Block Ripoptosome Formation, a RIP1/Caspase-8 Containing Intracellular Cell Death Complex Differentially Regulated by cFLIP Isoforms. Mol. Cell 2011, 43, 449-463. [CrossRef]

101. O'Brien, J.; Wilson, I.; Orton, T.; Pognan, F. Investigation of the Alamar Blue (resazurin) fluorescent dye for the assessment of mammalian cell cytotoxicity. Eur. J. Biochem. 2000, 267, 5421-5426. [CrossRef]

102. Ansar Ahmed, S.; Gogal, R.M.; Walsh, J.E. A new rapid and simple non-radioactive assay to monitor and determine the proliferation of lymphocytes: An alternative to [3H]thymidine incorporation assay. J. Immunol. Methods 1994, 170, 211-224. [CrossRef]

103. Page, B.; Page, M.; Noel, C. A new fluorometric assay for cytotoxicity measurements in vitro. Int. J. Oncol. 1993, 3, 473-476. [CrossRef] 
104. Pace, R.T.; Burg, K.J.L. Toxic effects of resazurin on cell cultures. Cytotechnology 2015, 67, 13-17. [CrossRef]

105. Schreer, A.; Tinson, C.; Sherry, J.P.; Schirmer, K. Application of Alamar blue/5-carboxyfluorescein diacetate acetoxymethyl ester as a noninvasive cell viability assay in primary hepatocytes from rainbow trout. Anal. Biochem. 2005, 344, 76-85. [CrossRef]

106. Ganassi, R.C.; Schirmer, K.; Bols, N.C. Cell and tissue culture. In The Laboratory Fish; Ostrander, G.K., Ed.; Academic Press: San Diego, CA, USA, 2000; pp. 631-651.

107. Sidman, R.L.; Miale, I.L.; Feder, N. Cell proliferation and migration in the primitive ependymal zone; An autoradiographic study of histogenesis in the nervous system. Exp. Neurol. 1959, 1, 322-333. [CrossRef]

108. Miller, M.W.; Nowakowski, R.S. Use of bromodeoxyuridine-immunohistochemistry to examine the proliferation, migration and time of origin of cells in the central nervous system. Brain Res. 1988, 457, 44-52. [CrossRef]

109. Salic, A.; Mitchison, T.J. A chemical method for fast and sensitive detection of DNA synthesis in vivo. Proc. Natl. Acad. Sci. USA 2008, 105, 2415-2420. [CrossRef]

110. Nowakowski, R.S.; Lewin, S.B.; Miller, M.W. Bromodeoxyuridine immunohistochemical determination of the lengths of the cell cycle and the DNA-synthetic phase for an anatomically defined population. J. Neurocytol. 1989, 18, 311-318. [CrossRef]

111. Taupin, P. BrdU immunohistochemistry for studying adult neurogenesis: Paradigms, pitfalls, limitations, and validation. Brain Res. Rev. 2007, 53, 198-214. [CrossRef]

112. Duque, A.; Rakic, P. Different effects of BrdU and (3)H-thymidine incorporation into DNA on cell proliferation, position and fate. J. Neurosci. Off. J. Soc. Neurosci. 2001, 31, 15205-15217. [CrossRef]

113. Maehara, Y.; Anai, H.; Tamada, R.; Sugimachi, K. The ATP assay is more sensitive than the succinate dehydrogenase inhibition test for predicting cell viability. Eur. J. Cancer Clin. Oncol. 1987, 23, 273-276. [CrossRef]

114. García, O.; Massieu, L. Glutamate Uptake Inhibitor L-Trans-Pyrrolidine 2,4-Dicarboxylate Becomes Neurotoxic in the Presence of Subthreshold Concentrations of Mitochondrial Toxin 3-Nitropropionate: Involvement of Mitochondrial Reducing Activity and ATP Production. J. Neurosci. Res. 2003, 74, 956-966. [CrossRef]

115. Andreotti, P.E.; Hartmann, D.M.; Linder, D.; Harel, G.; Gleiberman, I.; Caruso, P.A.; Ricks, S.H.; Cree, I.A.; Kurbacher, C.M.; Untch, M.; et al. Chemosensitivity Testing of Human Tumors Using a Microplate Adenosine Triphosphate Luminescence Assay: Clinical Correlation for Cisplatin Resistance of Ovarian Carcinoma. Cancer Res. 1995, 55, 5276-5282.

116. Duellman, S.J.; Zhou, W.; Meisenheimer, P.; Vidugiris, G.; Cali, J.J.; Gautam, P.; Wennerberg, K.; Vidugiriene, J. Bioluminescent, Nonlytic, Real-Time Cell Viability Assay and Use in Inhibitor Screening. Assay Drug Dev. Technol. 2015, 13, 456-465. [CrossRef]

117. Suzuki, T.; Fujikura, K.; Higashiyama, T.; Takata, K. DNA staining for fluorescence and laser confocal microscopy. J. Histochem. Cytochem. 1997, 45, 49-53. [CrossRef]

118. Liu, X.; Chen, H.; Patel, D.J. Solution structure of actinomycin-DNA complexes: Drug intercalation at isolated G-C sites. J. Biomol. NMR 1991, 1, 323-347. [CrossRef]

119. Latt, S.A. Fluorescent probes of chromosome structure and replication. Can. J. Genet. Cytol. 1977, 19, 603-623. [CrossRef]

120. Liu, W.; Liang, Y.; Chan, Q.; Jiang, L.; Dong, J. CX3CL1 promotes lung cancer cell migration and invasion via the Src/focal adhesion kinase signaling pathway. Oncol. Rep. 2019, 41, 1911-1917. [CrossRef]

121. Réu, P.; Svedberg, G.; Hässler, L.; Möller, B.; Svahn, H.A.; Gantelius, J. A 61\% lighter cell culture dish to reduce plastic waste. PLoS ONE 2019, 14, e0216251. [CrossRef]

122. Avlasevich, S.L.; Bryce, S.M.; Cairns, S.E.; Dertinger, S.D. In vitro micronucleus scoring by flow cytometry: Differential staining of micronuclei versus apoptotic and necrotic chromatin enhances assay reliability. Environ. Mol. Mutagen. 2006, 47, 56-66. [CrossRef]

123. Yan, X.; Habbersett, R.C.; Cordek, J.M.; Nolan, J.P.; Yoshida, T.M.; Jett, J.H.; Marrone, B.L. Development of a mechanism-based, DNA staining protocol using SYTOX orange nucleic acid stain and DNA fragment sizing flow cytometry. Anal. Biochem. 2000, 286, 138-148. [CrossRef]

124. Bryce, S.M.; Bemis, J.C.; Avlasevich, S.L.; Dertinger, S.D. In vitro micronucleus assay scored by flow cytometry provides a comprehensive evaluation of cytogenetic damage and cytotoxicity. Mutat. Res. 2007, 630, 78-91. [CrossRef]

125. Mukhopadhyay, P.; Rajesh, M.; Haskó, G.; Hawkins, B.J.; Madesh, M.; Pacher, P. Simultaneous detection of apoptosis and mitochondrial superoxide production in live cells by flow cytometry and confocal microscopy. Nat. Protoc. 2007, 2, 2295-2301. [CrossRef]

126. Kerscher, B.; Barlow, J.L.; Rana, B.M.; Jolin, H.E.; Gogoi, M.; Bartholomew, M.A.; Jhamb, D.; Pandey, A.; Tough, D.F.; Van Oosterhout, A.J.M.; et al. BET bromodomain inhibitor IBET151 impedes human ILC2 activation and prevents experimental allergic lung inflammation. Front. Immunol. 2019, 10, 678. [CrossRef]

127. Paivandy, A.; Eriksson, J.; Melo, F.R.; Sellin, M.E.; Pejler, G. Lysosomotropic challenge of mast cells causes intra-granular reactive oxygen species production. Cell Death Discov. 2019, 5, 95. [CrossRef]

128. Vig, S.; Buitinga, M.; Rondas, D.; Crèvecoeur, I.; van Zandvoort, M.; Waelkens, E.; Eizirik, D.L.; Gysemans, C.; Baatsen, P.; Mathieu, C.; et al. Cytokine-induced translocation of GRP78 to the plasma membrane triggers a pro-apoptotic feedback loop in pancreatic beta cells. Cell Death Dis. 2019, 10, 309. [CrossRef]

129. Akagi, J.; Kordon, M.; Zhao, H.; Matuszek, A.; Dobrucki, J.; Errington, R.; Smith, P.J.; Takeda, K.; Darzynkiewicz, Z.; Wlodkowic, D. Real-time cell viability assays using a new anthracycline derivative DRAQ7 ${ }^{\circledR}$. Cytom. Part A 2013, 83 A, 227-234. [CrossRef]

130. Severini, A.; Richard Morgan, A. An assay for proteinases and their inhibitors based on DNA/ethidium bromide fluorescence. Anal. Biochem. 1991, 193, 83-89. [CrossRef] 
131. Zipper, H.; Brunner, H.; Bernhagen, J.; Vitzthum, F. Investigations on DNA intercalation and surface binding by SYBR Green I, its structure determination and methodological implications. Nucleic Acids Res. 2004, 32, e103. [CrossRef]

132. Singer, V.L.; Lawlor, T.E.; Yue, S. Comparison of SYBR ${ }^{\circledR}$ Green I nucleic acid gel stain mutagenicity and ethidium bromide mutagenicity in the Salmonella/mammalian microsome reverse mutation assay (Ames test). Mutat. Res. Genet. Toxicol. Environ. Mutagen. 1999, 439, 37-47. [CrossRef]

133. Mirrett, S. Acridin orange stain. Infect. Control. 1982, 3, 250-252. [CrossRef]

134. Kumar, R.; Kaur, M.; Kumari, M. Acridine: A versatile heterocyclic nucleus. Acta Pol. Pharm. Drug Res. 2012, 69, 3-9.

135. Darzynkiewicz, Z.; Juan, G.; Srour, E.F. Differential staining of DNA and RNA. Curr. Protoc. Cytom. 2004, 30, 7.3.1-7.3.16. [CrossRef]

136. Lekishvili, T.; Campbell, J.J. Rapid comparative immunophenotyping of human mesenchymal stromal cells by a modified fluorescent cell barcoding flow cytometric assay. Cytom. Part A 2018, 93, 905-915. [CrossRef] [PubMed]

137. BD Biosciences. BD Biosciences Brochure. Available online: https://www.bdbiosciences.com/en-eu/applications/researchapplications/multicolor-flow-cytometry (accessed on 23 November 2021).

138. Prado-Garcia, H.; Romero-Garcia, S.; Rumbo-Nava, U.; Lopez-Gonzalez, J.S. Predominance of Th17 over regulatory T-cells in pleural effusions of patients with lung cancer implicates a proinflammatory profile. Anticancer Res. 2015, 35, $1529-1536$.

139. McMaster, S.R.; Gabbard, J.D.; Koutsonanos, D.G.; Compans, R.W.; Tripp, R.A.; Tompkins, S.M.; Kohlmeier, J.E. Memory T cells generated by prior exposure to influenza cross react with the novel H7N9 influenza virus and confer protective heterosubtypic immunity. PLoS ONE 2015, 10, e0115725. [CrossRef] [PubMed]

140. Rodríguez-Rodríguez, N.; Apostolidis, S.A.; Penaloza-MacMaster, P.; Martín Villa, J.M.; Barouch, D.H.; Tsokos, G.C.; Crispín, J.C. Programmed Cell Death 1 and Helios Distinguish TCR- $\alpha \beta+$ Double-Negative (CD4 - CD8 -) T Cells That Derive from Self-Reactive CD8 T Cells. J. Immunol. 2015, 194, 4207-4214. [CrossRef]

141. Flies, D.B.; Higuchi, T.; Chen, L. Mechanistic Assessment of PD-1H Coinhibitory Receptor-Induced T Cell Tolerance to Allogeneic Antigens. J. Immunol. 2015, 194, 5294-5304. [CrossRef] [PubMed]

142. Akabane, S.; Matsuzaki, K.; Yamashita, S.I.; Arai, K.; Okatsu, K.; Kanki, T.; Matsuda, N.; Oka, T. Constitutive activation of PINK1 protein leads to proteasome-mediated and non-apoptotic cell death independently of mitochondrial autophagy. J. Biol. Chem. 2016, 291, 16162-16174. [CrossRef]

143. Iraolagoitia, X.L.R.; Spallanzani, R.G.; Torres, N.I.; Araya, R.E.; Ziblat, A.; Domaica, C.I.; Sierra, J.M.; Nuñez, S.Y.; Secchiari, F.; Gajewski, T.F.; et al. NK Cells Restrain Spontaneous Antitumor CD8 + T Cell Priming through PD-1/PD-L1 Interactions with Dendritic Cells. J. Immunol. 2016, 197, 953-961. [CrossRef]

144. Mercer, F.; Diala, F.G.I.; Chen, Y.P.; Molgora, B.M.; Ng, S.H.; Johnson, P.J. Leukocyte Lysis and Cytokine Induction by the Human Sexually Transmitted Parasite Trichomonas vaginalis. PLoS Negl. Trop. Dis. 2016, 10, e0004913. [CrossRef]

145. Souza-Fonseca-Guimaraes, F.; Young, A.; Mittal, D.; Martinet, L.; Bruedigam, C.; Takeda, K.; Andoniou, C.E.; Degli-Esposti, M.A.; Hill, G.R.; Smyth, M.J. NK cells require IL-28R for optimal in vivo activity. Proc. Natl. Acad. Sci. USA 2015, 112, E2376-E2384. [CrossRef]

146. Matsui, K.; Adelsberger, J.W.; Kemp, T.J.; Baseler, M.W.; Ledgerwood, J.E.; Pinto, L.A. Circulating CXCR5+CD4+ T follicular-like helper cell and memory B cell responses to human papillomavirus vaccines. PLoS ONE 2015, 10, e0137195. [CrossRef]

147. Jones, A.; Opejin, A.; Henderson, J.G.; Gross, C.; Jain, R.; Epstein, J.A.; Flavell, R.A.; Hawiger, D. Peripherally Induced Tolerance Depends on Peripheral Regulatory T Cells That Require Hopx to Inhibit Intrinsic IL-2 Expression. J. Immunol. 2015, 195, 1489-1497. [CrossRef]

148. Nath, A.; Li, I.; Roberts, L.R.; Chan, C. Elevated free fatty acid uptake via CD36 promotes epithelial-mesenchymal transition in hepatocellular carcinoma. Sci. Rep. 2015, 5, 14752. [CrossRef]

149. Kanemaru, K.; Noguchi, E.; Tokunaga, T.; Nagai, K.; Hiroyama, T.; Nakamura, Y.; Tahara-Hanaoka, S.; Shibuya, A. Tie2 Signaling Enhances Mast Cell Progenitor Adhesion to Vascular Cell Adhesion Molecule-1 (VCAM-1) through $\alpha 4 \beta 1$ Integrin. PLoS ONE 2015, 10, e0144436. [CrossRef]

150. Talabot-Ayer, D.; Martin, P.; Vesin, C.; Seemayer, C.A.; Vigne, S.; Gabay, C.; Palmer, G. Severe Neutrophil-Dominated Inflammation and Enhanced Myelopoiesis in IL-33-Overexpressing CMV/IL33 Mice. J. Immunol. 2015, 194, 750-760. [CrossRef]

151. Keppel, M.P.; Saucier, N.; Mah, A.Y.; Vogel, T.P.; Cooper, M.A. Activation-Specific Metabolic Requirements for NK Cell IFN- $\gamma$ Production. J. Immunol. 2015, 194, 1954-1962. [CrossRef]

152. Shade, K.T.C.; Platzer, B.; Washburn, N.; Mani, V.; Bartsch, Y.C.; Conroy, M.; Pagan, J.D.; Bosques, C.; Mempel, T.R.; Fiebiger, E.; et al. A single glycan on IgE is indispensable for initiation of anaphylaxis. J. Exp. Med. 2015, 212, 457-467. [CrossRef]

153. Weiser, J.N.; Roche, A.M.; Hergott, C.B.; LaRose, M.I.; Connolly, T.; Jorgensen, W.L.; Leng, L.; Bucala, R.; Das, R. Macrophage Migration Inhibitory Factor Is Detrimental in Pneumococcal Pneumonia and a Target for Therapeutic Immunomodulation. J. Infect. Dis. 2015, 212, 1677-1682. [CrossRef]

154. Allen, T.M.; Cleland, L.G. Serum-induced leakage of liposome contents. BBA Biomembr. 1980, 597, 418-426. [CrossRef]

155. Patel, H.; Tscheka, C.; Heerklotz, H. Characterizing vesicle leakage by fluorescence lifetime measurements. Soft Matter 2009, 5, 2849-2851. [CrossRef]

156. Szakács, G.; Váradi, A.; Özvegy-Laczka, C.; Sarkadi, B. The role of ABC transporters in drug absorption, distribution, metabolism, excretion and toxicity (ADME-Tox). Drug Discov. Today 2008, 13, 379-393. [CrossRef] 
157. Tóvári, J.; Futosi, K.; Bartal, A.; Tátrai, E.; Gacs, A.; Kenessey, I.; Paku, S. Boyden chamber-based method for characterizing the distribution of adhesions and cytoskeletal structure in HT1080 fibrosarcoma cells. Cell Adhes. Migr. 2014, 8, 509-516. [CrossRef]

158. Khalili, A.A.; Ahmad, M.R. A Review of cell adhesion studies for biomedical and biological applications. Int. J. Mol. Sci. 2015, 16, 18149-18184. [CrossRef]

159. Zepeda-Moreno, A.; Taubert, I.; Hellwig, I.; Hoang, V.; Pietsch, L.; Lakshmanan, V.K.; Wagner, W.; Ho, A.D. Innovative method for quantification of cell-cell adhesion in 96-well plates. Cell Adhes. Migr. 2011, 5, 215-219. [CrossRef]

160. Kashef, J.; Franz, C.M. Quantitative methods for analyzing cell-cell adhesion in development. Dev. Biol. 2015, 401, 165-174. [CrossRef]

161. Zhou, D.W.; García, A.J. Measurement Systems for Cell Adhesive Forces. J. Biomech. Eng. 2015, 137, 020908. [CrossRef]

162. Ungai-Salánki, R.; Peter, B.; Gerecsei, T.; Orgovan, N.; Horvath, R.; Szabó, B. A practical review on the measurement tools for cellular adhesion force. Adv. Colloid Interface Sci. 2019, 269, 309-333. [CrossRef]

163. Kramer, N.; Walzl, A.; Unger, C.; Rosner, M.; Krupitza, G.; Hengstschläger, M.; Dolznig, H. In vitro cell migration and invasion assays. Mutat. Res. Rev. Mutat. Res. 2013, 752, 10-24. [CrossRef]

164. Boyden, S. The chemotactic effect of mixtures of antibody and antigen on polymorphonuclear leucocytes. J. Exp. Med. 1962, 115, 453-466. [CrossRef]

165. Restouin, A.; Aresta, S.; Prébet, T.; Borg, J.P.; Badache, A.; Collette, Y. A simplified, 96-well-adapted, ATP luminescence-based motility assay. Biotechniques 2009, 47, 871-875. [CrossRef]

166. Marshall, J. Transwell((R)) invasion assays. Methods Mol. Biol. 2011, 769, 97-110.

167. Liang, C.C.; Park, A.Y.; Guan, J.L. In vitro scratch assay: A convenient and inexpensive method for analysis of cell migration in vitro. Nat. Protoc. 2007, 2, 329-333. [CrossRef]

168. Gyorffy, B.; Stelniec-Klotz, I.; Sigler, C.; Kasack, K.; Redmer, T.; Qian, Y.; Schäfer, R. Effects of RAL signal transduction in KRASand BRAF-mutated cells and prognostic potential of the RAL signature in colorectal cancer. Oncotarget 2015, 6, 13334-13346. [CrossRef]

169. Gorshkova, I.; He, D.; Berdyshev, E.; Usatuyk, P.; Burns, M.; Kalari, S.; Zhao, Y.; Pendyala, S.; Garcia, J.G.N.; Pyne, N.J.; et al. Protein kinase $\mathrm{C}-\varepsilon$ regulates sphingosine 1-phosphate-mediated migration of human lung endothelial cells through activation of phospholipase D2, protein kinase C- $\zeta$, and Rac1. J. Biol. Chem. 2008, 283, 11794-11806. [CrossRef]

170. Lo, C.M.; Keese, C.R.; Giaever, I. Impedance analysis of MDCK cells measured by electric cell-substrate impedance sensing. Biophys. J. 1995, 69, 2800-2807. [CrossRef]

171. Tamada, M.; Perez, T.D.; Nelson, W.J.; Sheetz, M.P. Two distinct modes of myosin assembly and dynamics during epithelial wound closure. J. Cell Biol. 2007, 176, 27-33. [CrossRef]

172. Zordan, M.D.; Mill, C.P.; Riese, D.J.; Leary, J.F. A high throughput, interactive imaging, bright-field wound healing assay. Cytom. Part A 2011, 79 A, 227-232. [CrossRef]

173. Poujade, M.; Grasland-Mongrain, E.; Hertzog, A.; Jouanneau, J.; Chavrier, P.; Ladoux, B.; Buguin, A.; Silberzan, P. Collective migration of an epithelial monolayer in response to a model wound. Proc. Natl. Acad. Sci. USA 2007, 104, 15988-15993. [CrossRef]

174. Simpson, K.J.; Selfors, L.M.; Bui, J.; Reynolds, A.; Leake, D.; Khvorova, A.; Brugge, J.S. Identification of genes that regulate epithelial cell migration using an siRNA screening approach. Nat. Cell Biol. 2008, 10, 1027-1038. [CrossRef]

175. Gough, W.; Hulkower, K.I.; Lynch, R.; McGlynn, P.; Uhlik, M.; Yan, L.; Lee, J.A. A quantitative, facile, and high-throughput image-based cell migration method is a robust alternative to the scratch assay. J. Biomol. Screen. 2011, 16, 155-163. [CrossRef]

176. Leto, T.L.; Pratt, B.M.; Madri, J.A. Mechanisms of cytoskeletal regulation: Modulation of aortic endothelial cell protein band 4.1 by the extracellular matrix. J. Cell. Physiol. 1986, 127, 423-431. [CrossRef]

177. Varani, J.; Orr, W.; Ward, P.A. A comparison of the migration patterns of normal and malignant cells in two assay systems. Am. J. Pathol. 1978, 90, 159-172.

178. Kroening, S.; Goppelt-Struebe, M. Analysis of matrix-dependent cell migration with a barrier migration assay. Sci. Signal. 2010, 3, 1-11. [CrossRef] [PubMed]

179. Rosen, E.M.; Meromsky, L.; Setter, E.; Vinter, D.W.; Goldberg, I.D. Quantitation of cytokine-stimulated migration of endothelium and epithelium by a new assay using microcarrier beads. Exp. Cell Res. 1990, 186, 22-31. [CrossRef]

180. Konduri, S.D.; Tasiou, A.; Chandrasekar, N.; Rao, J.S. Overexpression of tissue factor pathway inhibitor-2 (TFPI-2), decreases the invasiveness of prostate cancer cells in vitro. Int. J. Oncol. 2001, 18, 127-131. [CrossRef] [PubMed]

181. Chaubey, S.; Ridley, A.J.; Wells, C.M. Using the Dunn Chemotaxis Chamber to Analyze Primary Cell Migration in Real Time, in Cell Migration: Developmental Methods and Protocols. Methods Mol. Biol. 2011, 769, 41-51. [CrossRef]

182. Echeverria, V.; Meyvantsson, I.; Skoien, A.; Worzella, T.; Lamers, C.; Hayes, S. An automated high-content assay for tumor cell migration through 3-Dimensional matrices. J. Biomol. Screen. 2010, 15, 1144-1151. [CrossRef] [PubMed]

183. Miura, K. Tracking movement in cell biology. Adv. Biochem. Eng. Biotechnol. 2005, 95, 267-295. [CrossRef] [PubMed]

184. Gu, W.; Pellegrino, T.; Parak, W.J.; Boudreau, R.; Le Gros, M.A.; Alivisatos, A.P.; Larabell, C.A. Measuring cell motility using quantum dot probes. Methods Mol. Biol. 2007, 374, 125-131. [CrossRef]

185. Lin, M.; DiVito, M.M.; Merajver, S.D.; Boyanapalli, M.; van Golen, K.L. Regulation of pancreatic cancer cell migration and invasion by RhoC GTPase and caveolin-1. Mol. Cancer 2005, 4, 21. [CrossRef]

186. Niinaka, Y.; Haga, A.; Raz, A. Quantification of cell motility. Metastasis Res. Protoc. 2001, 58, 55-60. 
187. Swaminathan, V.; Mythreye, K.; Tim O’Brien, E.; Berchuck, A.; Blobe, G.C.; Superfine, R. Mechanical Stiffness grades metastatic potential in patient tumor cells and in cancer cell lines. Cancer Res. 2011, 71, 5075-5080. [CrossRef]

188. Cribb, J.A.; Osborne, L.D.; Beicker, K.; Psioda, M.; Chen, J.; O’Brien, E.T.; Taylor, R.M.; Vicci, L.; Hsiao, J.P.L.; Shao, C.; et al. An Automated High-throughput Array Microscope for Cancer Cell Mechanics. Sci. Rep. 2016, 6, 27371. [CrossRef]

189. Hillman, H. Procedures used in modern cell biology ignore natural laws. J. Biol. Phys. Chem. 2009, 9, 130-135. [CrossRef]

190. Ramsden, J.J. Towards zero-perturbation methods for investigating biomolecular interactions. Colloids Surf. A Physicochem. Eng. Asp. 1998, 141, 287-294. [CrossRef]

191. Ramsden, J.J. Experimental methods for investigating protein adsorption kinetics at surfaces. Q. Rev. Biophys. 1993, 27, 41-105. [CrossRef]

192. Ramsden, J.J. Optical biosensors. J. Mol. Recog. 1997, 10, 109-120. [CrossRef]

193. Song, H.P.; Wang, H.; Zhao, X.; He, L.; Zhong, H.; Wu, S.Q.; Li, P.; Yang, H. Label-free pharmacological profiling based on dynamic mass redistribution for characterization and authentication of hazardous natural products. J. Hazard. Mater. 2017, 333, 265-274. [CrossRef]

194. Zhang, X.; Deng, H.; Xiao, Y.; Xue, X.; Ferrie, A.M.; Tran, E.; Liang, X.; Fang, Y. Label-free cell phenotypic profiling identifies pharmacologically active compounds in two traditional Chinese medicinal plants. RSC Adv. 2014, 4, 26368-26377. [CrossRef]

195. Peter, B.; Nador, J.; Juhasz, K.; Dobos, A.; Korosi, L.; Székács, I.; Patko, D.; Horvath, R. Incubator proof miniaturized Holomonitor to in situ monitor cancer cells exposed to green tea polyphenol and preosteoblast cells adhering on nanostructured titanate surfaces: Validity of the measured parameters and their corrections. J. Biomed. Opt. 2015, 20, 067002. [CrossRef]

196. McColl, J.; Horvath, R.; Aref, A.; Larcombe, L.; Chianella, I.; Morgan, S.; Yakubov, G.E.; Ramsden, J.J. Polyphenol control of cell spreading on glycoprotein substrata. J. Biomater. Sci. Polym. Ed. 2009, 20, 841-851. [CrossRef]

197. Orgovan, N.; Peter, B.; Bősze, S.; Ramsden, J.J.; Szabó, B.; Horvath, R. Dependence of cancer cell adhesion kinetics on integrin ligand surface density measured by a high-throughput label-free resonant waveguide grating biosensor. Sci. Rep. 2014, 4, 4034. [CrossRef]

198. Aref, A.; Horvath, R.; Ramsden, J.J. Spreading kinetics for quantifying cell state during stem cell differentiation. J. Biol. Phys. Chem. 2010, 10, 145-151. [CrossRef]

199. Ramsden, J.J. Biospecific interaction analysis using integrated optics techniques. In Quantitative Analysis of Biospecific Interactions; Lundahl, P., Lundqvist, A., Greijer, E., Eds.; Harwood: Amsterdam, The Netherlands, 1998; pp. 149-162.

200. Michielin, O.; Vergères, G.; Ramsden, J.J. Myristoylation-induced compaction of a membrane-binding protein. J. Am. Chem. Soc. 1999, 121, 6523-6526. [CrossRef]

201. Shanshiashvili, L.V.; Suknidze, N.C.; Machaidze, G.G.; Mikeladze, D.G.; Ramsden, J.J. Adhesion and clustering of charge isomers of myelin basic protein at model myelin membranes. Arch. Biochem. Biophys. 2003, 419, 170-177. [CrossRef] [PubMed]

202. Vergères, G. and Ramsden, J.J. Regulation of the binding of MARCKS-related protein to lipid bilayer membranes by calmodulin. Arch. Biochem. Biophys. 2000, 378, 45-50. [CrossRef]

203. Ramsden, J.J. OWLS-A versatile technique for drug discovery. Front. Drug Des. Discov. 2006, 2, $211-223$.

204. Nikolelis, D.P.; Nikoleli, G.P. Biosensors for Security and Bioterrorism Applications; Springer International Publishing: Cham, Switzerland, 2016. [CrossRef]

205. Ramsden, J.J. From Kinetics to Structure: High resolution molecular microscopy. In Proteins at Solid-Liquid Interfaces; Dejardin, P., Ed.; Springer: Berlin/Heidelberg, Germany, 2006; pp. 23-49.

206. Horvath, R.; McColl, J.; Yakubov, G.E.; Ramsden, J.J. Structural hysteresis and hierarchy in adsorbed glycoproteins. J. Chem. Phys. 2008, 129, 08B401. [CrossRef]

207. Saftics, A.; Kurunczi, S.; Peter, B.; Szekacs, I.; Ramsden, J.J.; Horvath, R. Data evaluation for surface-sensitive label-free methods to obtain real-time kinetic and structural information of thin films: A practical review with related software packages. Adv. Colloid Interface Sci. 2021, 294, 102431. [CrossRef] [PubMed]

208. Jankovics, H.; Kovacs, B.; Saftics, A.; Gerecsei, T.; Tóth, É.; Szekacs, I.; Vonderviszt, F.; Horvath, R. Grating-coupled interferometry reveals binding kinetics and affinities of $\mathrm{Ni}$ ions to genetically engineered protein layers. Sci. Rep. 2020, 10, 22253. [CrossRef]

209. Kliment, K.; Szekacs, I.; Peter, B.; Erdei, A.; Kurucz, I.; Horvath, R. Biosensors and Bioelectronics Label-free real-time monitoring of the BCR-triggered activation of primary human B cells modulated by the simultaneous engagement of inhibitory receptors. Biosens. Bioelectron. 2021, 191, 113469. [CrossRef]

210. Sztilkovics, M.; Gerecsei, T.; Peter, B.; Saftics, A.; Kurunczi, S.; Szekacs, I.; Szabo, B.; Horvath, R. Single-cell adhesion force kinetics of cell populations from combined label-free optical biosensor and robotic fluidic force microscopy. Sci. Rep. 2020, 10, 61. [CrossRef]

211. Ramsden, J.J.; Li, S.-Y.; Heinzle, E.; Prenosil, J.E. Optical method for measurement of number and shape of attached cells in real time. Cytometry 1995, 1, 97-102. [CrossRef]

212. Wang, R.; Wang, J.; Liu, Y.; Zhang, X.; Liang, X. Resonant waveguide grating based assays for colloidal aggregate detection and promiscuity characterization in natural products. RSC Adv. 2019, 9, 38055-38064. [CrossRef]

213. Persson, J.; Mölder, A.; Pettersson, S.; Alm, K. Cell motility studies using digital holographic microscopy. Education 2010, 1063-1072.

214. El-Schish, Z.; Mölder, A.; Sebesta, M.; Gisselsson, L.; Alm, K.; Gjörloff, A.; Wingren, A. Digital holographic microscopy-Innovative and non-destructive analysis of living cells. Microsc. Sci. Technol. Appl. Educ. 2010, 4, 1055-1062. 
215. Murray, E.M.; Allen, C.F.; Handy, T.E.; Hu, C.A.; Craig, W.R.; Seaton, S.C.; Wolfe, A.L. Development of a Robust and Quantitative High-Throughput Screening Method for Antibiotic Production in Bacterial Libraries. ACS Omega 2019, 4, 15414-15420. [CrossRef]

216. Cordell, G.A.; Shin, Y.G. Finding the needle in the haystack. The dereplication of natural product extracts. Pure Appl. Chem. 1999, 71, 1089-1094. [CrossRef]

217. Dias, D.A.; Urban, S.; Roessner, U. A Historical Overview of Natural Products in Drug Discovery. Metabolites 2012, 303-336. [CrossRef] [PubMed]

218. Newman, D.J.; Cragg, G.M. Natural Products as Sources of New Drugs over the Nearly Four Decades from 01/1981 to 09/2019. J. Nat. Prod. 2020, 83, 770-803. [CrossRef] [PubMed]

219. Atanasov, A.G.; Zotchev, S.B.; Dirsch, V.M.; Orhan, I.E.; Banach, M.; Rollinger, J.M.; Barreca, D.; Weckwerth, W.; Bauer, R.; Bayer, E.A.; et al. Natural products in drug discovery: Advances and opportunities. Nat. Rev. Drug Discov. 2021, 20, 200-216. [CrossRef]

220. Thomford, N.E.; Senthebane, D.A.; Rowe, A.; Munro, D.; Seele, P.; Maroyi, A.; Dzobo, K. Natural products for drug discovery in the 21st century: Innovations for novel drug discovery. Int. J. Mol. Sci. 2018, 19, 1578. [CrossRef]

221. Walker, J.M. Natural products isolation. In Methods in Biotechnology; Sarker, S.D., Latif, Z., Gray, A.I., Eds.; Humana Press Inc: Totowa, NJ, USA, 2005.

222. Sarker, S.D.; Nahar, L. An Introduction to Natural Products Isolation. Methods Mol. Biol. 2012, 864, 1-25. [CrossRef] [PubMed]

223. Zhang, Q.W.; Lin, L.G.; Ye, W.C. Techniques for extraction and isolation of natural products: A comprehensive review. Chin. Med. 2018, 13, 20. [CrossRef]

224. Cavalcanti, R.N. Uses and Applications of Extracts from Natural Sources. In RSC Green Chemistry No. 21 Natural Product Extraction: Principles and Applications; Rostagno, M.A., Prado, J.M., Eds.; The Royal Society of Chemistry: London, UK, 2013.

225. Li, J.; Hu, S.; Jian, W.; Xie, C.; Yang, X. Plant antimicrobial peptides: Structures, functions, and applications. Bot. Stud. 2021, 62, 5. [CrossRef] [PubMed]

226. Dos Santos-Silva, C.A.; Zupin, L.; Oliveira-Lima, M.; Vilela, L.M.B.; Bezerra-Neto, J.P.; Ferreira-Neto, J.R.; Ferreira, J.D.C.; de Oliveira-Silva, R.L.; de J. Pires, C.; Aburjaile, F.F.; et al. Plant Antimicrobial Peptides: State of the Art, In Silico Prediction and Perspectives in the Omics Era. Bioinform. Biol. Insights 2020, 14, 1177932220952739. [CrossRef]

227. Hegedüs, N.; Marx, F. Antifungal proteins: More than antimicrobials? Fungal Biol. Rev. 2013, 26, 132-145. [CrossRef]

228. Shwaiki, L.N.; Lynch, K.M.; Arendt, E.K. Future of antimicrobial peptides derived from plants in food application-A focus on synthetic peptides. Trends Food Sci. Technol. 2021, 112, 312-324. [CrossRef]

229. Xiang, L.; Chi, T.; Tang, Q.; Yang, X.; Ou, M.; Chen, X.; Yu, X.; Chen, J.; Ho, R.J.Y.; Shao, J.; et al. A pentacyclic triterpene natural product, ursolic acid and its prodrug US597 inhibit targets within cell adhesion pathway and prevent cancer metastasis. Oncotarget 2015, 6, 9295-9312. [CrossRef]

230. Rahimi-Esboei, B.; Ebrahimzadeh, M.A.; Gholami, S.H.; Falah-Omrani, V. Anti-giardial activity of Sambucus ebulus. Eur. Rev. Med. Pharmacol. Sci. 2013, 17, 2047-2050. [CrossRef] [PubMed]

231. Suzuki, Y.; Isemura, M. Inhibitory effect of epigallocatechin gallate on adhesion of murine melanoma cells to laminin. Cancer Lett. 2001, 173, 15-20. [CrossRef]

232. De Campos, P.S.; Matte, B.F.; Diel, L.F.; Jesus, L.H.; Bernardi, L.; Alves, A.M.; Rados, P.V.; Lamers, M.L. Low Doses of Curcuma longa Modulates Cell Migration and Cell-Cell Adhesion. Phyther. Res. 2017, 31, 1433-1440. [CrossRef] [PubMed]

233. Kim, J.D.; Liu, L.; Guo, W.; Meydani, M. Chemical structure of flavonols in relation to modulation of angiogenesis and immuneendothelial cell adhesion. J. Nutr. Biochem. 2006, 17, 165-176. [CrossRef] [PubMed]

234. Liu, J.M.; Bignon, J.; Haroun-Bouhedja, F.; Bittoun, P.; Vassy, J.; Fermandjian, S.; Wdzieczak-Bakala, J.; Boisson-Vidal, C. Inhibitory effect of fucoidan on the adhesion of adenocarcinoma cells to fibronectin. Anticancer Res. 2005, 25, 2129-2133.

235. Di Mattia, C.; Battista, N.; Sacchetti, G.; Serafini, M. Antioxidant Activities in vitro of Water and Liposoluble Extracts Obtained by Different Species of Edible Insects and Invertebrates. Front. Nutr. 2019, 6, 106. [CrossRef]

236. Arancibia-avila, P.; Fuentes, O.; Alarco, J.; Zamorano-ponce, E.; Herna, M. Production and Purification of Statins from Pleurotus ostreatus (Basidiomycetes ) Strains. Z. Naturforsch. C J. Biosci. 2003, 58, 62-64.

237. Tamura, C.; Terahara, A. ML-236A, ML-236B, and ML-236C, new inhibitors of cholesterogenesis produced by Penicillium citrinium. J. Antibiot. 1976, 29, 1346-1348.

238. Altwairgi, A.K. Statins are potential anticancerous agents. Oncol. Rep. 2015, 33, 1019-1039. [CrossRef]

239. Gazzerro, P.; Proto, M.C.; Gangemi, G.; Malfitano, A.M.; Ciaglia, E.; Pisanti, S.; Santoro, A. Pharmacological Actions of Statins: A Critical Appraisal in the Management of Cancer. Pharmacol. Rev. 2012, 64, 102-146. [CrossRef]

240. Iannelli, F.; Lombardi, R.; Milone, M.R.; Pucci, B.; Rienzo, S. De Targeting Mevalonate Pathway in Cancer Treatment: Repurposing of Statins. Recent Pat. Anticancer Drug Discov. 2018, 13, 184-200. [CrossRef]

241. Takamatsu, S. Naturally occurring cell adhesion inhibitors. J. Nat. Med. 2018, 72, 817-835. [CrossRef] [PubMed]

242. Schreiner, E.P.; Kern, M.; Steck, A.; Foster, C.A. Synthesis of ether analogues derived from HUN-7293 and evaluation as inhibitors of VCAM-1 expression. Bioorgan. Med. Chem. Lett. 2004, 14, 5003-5006. [CrossRef]

243. Takamatsu, S.; Zhang, Q.; Schrader, K.K.; ElSohly, H.N.; Walker, L.A. Characterization of Mycotypha metabolites found ro be inhibitors of cell adhesion molecules. J. Antibiot. 2002, 55, 585-592. [CrossRef]

244. Jeong, J.; Jin, C.; Park, C.; Han, M.I.N.H.O.; Kim, G.; Moon, S.; Kim, C.G.I.L.; Jeong, Y.K.E.E.; Kim, W.; Lee, J.; et al. Inhibition of migration and invasion of LNCaP human prostate carcinoma cells by cordycepin through inactivation of Akt. Int. J. Oncol. 2012, 40, 1697-1704. [CrossRef] [PubMed] 
245. Xu, J.; Caro-diaz, E.J.E.; Lacoske, M.H.; Hung, C.; Theodorakis, E.A. EDGE ARTICLE Fusarisetin A: Scalable total synthesis and related studies. Chem. Sci. 2012, 12, 3378-3386. [CrossRef]

246. Kasorn, A.; Loison, F.; Kangsamaksin, T. Terrein inhibits migration of human breast cancer cells via inhibition of the Rho and Rac signaling pathways. Oncol. Rep. 2018, 39, 1378-1386. [CrossRef]

247. Mathieu, V.; Berger, W.; Evidente, A.; Kornienko, A.; Gailly, P.; Vandier, C. Ophiobolin A induces paraptosis-like cell death in human glioblastoma cells by decreasing BKCa channel activity. Cell Death Dis. 2013, 4, e561. [CrossRef]

248. Bury, M.; Andolfi, A.; Rogister, B.; Cimmino, A.; Mégalizzi, V.; Mathieu, V.; Feron, O.; Evidente, A.; Kiss, R. Fusicoccin A, a phytotoxic carbotricyclic diterpene glucoside of fungal Origin, reduces proliferation and invasion of glioblastoma cells by targeting multiple tyrosine kinases. Transl. Oncol. 2013, 6, 112-123. [CrossRef]

249. Teiten, M.; Mack, F.; Debbab, A.; Aly, A.H.; Dicato, M.; Proksch, P.; Diederich, M. Bioorganic \& Medicinal Chemistry Anticancer effect of altersolanol A, a metabolite produced by the endophytic fungus Stemphylium globuliferum, mediated by its proapoptotic and anti-invasive potential via the inhibition of NF-j B activity. Bioorgan. Med. Chem. 2013, 21, 3850-3858. [CrossRef]

250. Wang, X.; Bashyal, B.P.; Wijeratne, E.M.K.; Ren, J.M.U.; Liu, M.X.; Gunatilaka, M.K.; Arnold, A.E.; Gunatilaka, A.A.L. Smardaesidins A-G, Isopimarane and 20- nor -Isopimarane Diterpenoids from Smardaea sp., a Fungal Endophyte of the Moss Ceratodon purpureus 1. J. Nat. Prod. 2011, 74, 2052-2061. [CrossRef]

251. Lee, H.J.; Lee, J.H.; Hwang, B.Y.; Kim, H.S.; Lee, J.J. Anti-Angiogenic Activities of Gliotoxin and Its Methylthio- Derivative, Fungal Metabolites. Arch. Pharm. Res. 2001, 24, 397-401. [CrossRef]

252. Hayot, C.; Debeir, O.; Van Ham, P.; Van Damme, M.; Kiss, R.; Decaestecker, C. Characterization of the activities of actin-affecting drugs on tumor cell migration. Toxicol. Appl. Pharmacol. 2006, 211, 30-40. [CrossRef] [PubMed]

253. Zhou, C.; Ling, M.; Lee, T.K.; Man, K.; Wang, X.; Wong, Y. FTY720, a fungus metabolite, inhibits invasion ability of androgenindependent prostate cancer cells through. Cancer Lett. 2006, 233, 36-47. [CrossRef] [PubMed]

254. Kusama, T.; Mukai, M.; Iwasaki, T.; Tatsuta, M.; Matsumoto, Y.; Akedo, H. Inhibition of Epidermal Growth Factor-induced RhoA Translocation and Invasion of Human Pancreatic Cancer Cells by 3-Hydroxy-3-methylglutaryl-coenzyme A. Cancer Res. 2001, 61, 4885-4891.

255. Alonso, D.F.; Farina, H.G.; Skilton, G.; Gabri, M.R.; de Lorenzo, M.S.; Gomez, D.E. Reduction of mouse mammary tumor formation and metastasis by lovastatin, an inhibitor of the mevalonate pathway ofcholesterol synthesis. Breast Cancer Res. Treat. 1998, 50, 83-93. [CrossRef]

256. Zhong, W.; Liang, Y.; Wang, C.; Chang, T.; Lee, W. Lovastatin suppresses invasiveness of anaplastic thyroid cancer cells by inhibiting Rho geranylgeranylation and RhoA / ROCK signaling. Endocr. Relat. Cancer 2005, 3, 615-630. [CrossRef]

257. Bublik, R.; Alonso, D.F.; Gomez, D.E. Lovastatin alters cytoskeleton organization and inhibits experimental metastasis of mammary carcinoma cells. Clin. Exp. Metastasis 2002, 19, 551-559.

258. Afshordel, S.; Kern, B.; Clasohm, J.; König, H.; Priester, M.; Weissenberger, J.; Kögel, D.; Eckert, G.P. Lovastatin and perillyl alcohol inhibit glioma cell invasion, migration, and proliferation-Impact of Ras-/Rho-prenylation. Pharmacol. Res. 2015, 91, 69-77. [CrossRef]

259. Glynn, S.A.; Sullivan, D.O.; Eustace, A.J.; Clynes, M.; Donovan, N.O. The 3-hydroxy-3-methylglutaryl-coenzyme A reductase inhibitors, invasion of melanoma cells. BMC Cancer 2008, 8, 9. [CrossRef] [PubMed]

260. Hayashi, M.; Kim, Y.P.; Hiraoka, H.; Natori, M.; Takamatsu, S.; Kawakubo, T.; Masuma, R.; Komiyama, K.; Somura, S. Macrosphelide, a novel inhibitor of cell-cell adhesion molecule. I. Taxonomy, fermentation, isolation and biological activities. J. Antibiot. 1995, 48, 1435-1439. [CrossRef]

261. Takamatsu, S.; Hiraoka, H.; Kim, Y.; Hayashi, M.; Natori, M.; Komiyama, K.; Omura, S. Macrosphelides C and D, Novel Inhibitors of Cell Adhesion. J. Antibiot. 1997, 50, 878-880. [CrossRef] [PubMed]

262. Fukami, A.; Taniguchi, Y.; Nakamura, T.; Rho, M.; Kawaguchi, K.; Hayashi, M.; Komiyama, K.; Omura, S. New Membersof the Macrosphelides from Microsphaeropsis sp. FO-5050 IV. J. Antibiot. 1999, 52, 501-504. [CrossRef]

263. Miki, I.; Ishihara, N.; Otoshi, M.; Kase, H. Simple colorimetric cell-cell adhesion assay using MTT-stained leukemia cells. J. Immunol. Methods 1993, 164, 255-261. [CrossRef]

264. Yamada, T.; Iritani, M.; Doi, M.; Minoura, K.; Ito, T.; Numata, A. Absolute stereostructures of cell-adhesion inhibitors, macrosphelides C, E-G and I, produced by a sea hare-derived Periconia sp. J. Antibiot. 2001, 3046-3053. [CrossRef]

265. Yamada, T.; Iritani, M.; Minoura, K.; Numata, A. Absolute Stereostructures of Cell Adhesion Inhibitors, Macrosphelides H and L, from Periconia byssoides OUPS-N133. J. Antibiot. 2002, 55, 147-154. [CrossRef] [PubMed]

266. Yamada, T.; Minoura, K.; Tanaka, R.; Numata, A. Cell-adhesion Inhibitors Produced by a Sea Hare-derived Periconia sp. J. Antibiot. 2007, 60, 370-375. [CrossRef]

267. Fukami, A.; Iijima, K.; Hayashi, M.; Komiyama, K.; Omura, S. Macrosphelide B Suppressed Metastasis through Inhibition of Adhesion of sLe x / E-Selectin Molecules. Biochem. Biophys. Res. Commun. 2002, 1070, 1065-1070. [CrossRef]

268. Yamada, T.; Iritani, M.; Minoura, K.; Kawai, K.; Numata, A. Peribysins A-D, potent cell-adhesion inhibitors from a sea harederived culture of Periconia species. Org. Biomol. Chem. 2004, 2, 2131-2135. [CrossRef]

269. Yamada, T.; Doi, M.; Miura, A.; Harada, W.; Hiramura, M.; Minoura, K.; Tanaka, R.; Numata, A. Absolute Stereostructures of Cell-adhesion Inhibitors, Peribysins A, E, F and G, Produced by a Sea Hare-derived Periconia sp. J. Antibiot. 2005, 58, 185-191. [CrossRef] 
270. Yamada, T.; Minoura, K.; Tanaka, R.; Numata, A. Cell-adhesion Inhibitors Produced by a Sea Hare-derived Periconia sp. II. J. Antibiot. 2006, 59, 345-350. [CrossRef]

271. Sigrist, C.J.A.; Bridge, A.; Le Mercier, P. A potential role for integrins in host cell entry by SARS-CoV-2. Antiviral Res. 2020, 177, 104759. [CrossRef] [PubMed]

272. Kiss, B.; Kis, Z.; Pályi, B.; Kellermayer, M.S.Z. Topography, Spike Dynamics, and Nanomechanics of Individual Native SARS-CoV2 Virions. Nano Lett. 2021, 21, 2675-2680. [CrossRef] [PubMed]

273. Kanyo, N.; Kovacs, K.D.; Saftics, A.; Szekacs, I.; Peter, B.; Santa-Maria, A.R.; Walter, F.R.; Dér, A.; Deli, M.A.; Horvath, R. Glycocalyx regulates the strength and kinetics of cancer cell adhesion revealed by biophysical models based on high resolution label-free optical data. Sci. Rep. 2020, 10, 22422. [CrossRef]

274. Dakal, T.C. SARS-CoV-2 attachment to host cells is possibly mediated via RGD-integrin interaction in a calcium-dependent manner and suggests pulmonary EDTA chelation therapy as a novel treatment for COVID 19. Immunobiology 2021, $226,152021$. [CrossRef] [PubMed]

275. Yang, Q.; Hughes, T.A.; Kelkar, A.; Yu, X.; Cheng, K.; Park, S.J.; Huang, W.C.; Lovell, J.F.; Neelamegham, S. Inhibition of SARS-CoV-2 viral entry in vitro upon blocking N- and O-glycan elaboration. bioRxiv 2020, 1-19. [CrossRef]

276. Bhuiyan, F.R.; Howlader, S.; Raihan, T.; Hasan, M. Plants Metabolites: Possibility of Natural Therapeutics Against the COVID-19 Pandemic. Front. Med. 2020, 7, 444. [CrossRef]

277. Antonelli, M.; Donelli, D.; Maggini, V.; Firenzuoli, F. Phytotherapic compounds against coronaviruses: Possible streams for future research. Phyther. Res. 2020, 34, 1469-1470. [CrossRef]

278. Seifert, G.; Jeitler, M.; Stange, R.; Michalsen, A.; Cramer, H.; Brinkhaus, B.; Esch, T.; Kerckhoff, A.; Paul, A.; Teut, M.; et al. The Relevance of Complementary and Integrative Medicine in the COVID-19 Pandemic: A Qualitative Review of the Literature. Front. Med. 2020, 7, 946. [CrossRef]

279. Subbaiyan, A.; Ravichandran, K.; Singh, S.V.; Sankar, M.; Thomas, P.; Dhama, K.; Malik, Y.S.; Singh, R.K.; Chaudhuri, P. In silico molecular docking analysis targeting SARS-CoV-2 Spike protein and selected herbal constituents. J. Pure Appl. Microbiol. 2020, 14, 989-998. [CrossRef]

280. Liu, J.; Bodnar, B.H.; Meng, F.; Khan, A.I.; Wang, X.; Saribas, S.; Wang, T.; Lohani, S.C.; Wang, P.; Wei, Z.; et al. Epigallocatechin gallate from green tea effectively blocks infection of SARS-CoV-2 and new variants by inhibiting spike binding to ACE2 receptor. Cell Biosci. 2021, 11, 1-15. [CrossRef]

281. Kalus, U.; Grigorov, A.; Kadecki, O.; Jansen, J.P.; Kiesewetter, H.; Radtke, H. Cistus incanus (CYSTUS052) for treating patients with infection of the upper respiratory tract. A prospective, randomised, placebo-controlled clinical study. Antiviral Res. 2009, 84, 267-271. [CrossRef] [PubMed]

282. Bramer, W.M.; De Jonge, G.B.; Rethlefsen, M.L.; Mast, F.; Kleijnen, J. A systematic approach to searching: An efficient and complete method to develop literature searches. J. Med. Libr. Assoc. 2018, 106, 531-541. [CrossRef] [PubMed] 